Max-Planck-Institut für demografische Forschung

Max Planck Institute for Demographic Research

Konrad-Zuse-Strasse 1 - D-18057 Rostock - GERMANY

$\mathrm{Tel}+49$ (0) 3812081 - 0; Fax +49 (0) 3812081 - 202;

http://www.demogr.mpg.de

MPIDR WORKING PAPER WP 2009-039

DECEMBER 2009

\title{
Social change and family change in a \\ Central European urban context: \\ Rostock 1819-1867
}

\author{
Mikołaj Szołtysek (szoltysek@demogr.mpg.de) \\ Siegfried Gruber (gruber@demogr.mpg.de) \\ Rembrandt Scholz \\ Barbara Zuber-Goldstein
}

(C) Copyright is held by the authors.

Working papers of the Max Planck Institute for Demographic Research receive only limited review. Views or opinions expressed in working papers are attributable to the authors and do not necessarily reflect those of the Institute. 


\title{
Mikołaj Szołtysek, Siegfried Gruber, Rembrandt Scholz and Barbara Zuber-Goldstein*
}

\author{
Social change and family change in a Central European urban \\ context: \\ Rostock 1819-1867
}

\begin{abstract}
$\underline{\text { Abstract }}$
This study is informed by competing perspectives on family behaviour in periods of turbulent social change, and intends to provide some fresh insights into the effect of macro-level changes on micro-level processes involving the family. In this pilot study, we take our first step towards analysing the impact of developing urban-industrial life on the family system in the northern German city of Rostock. A variety of quantitative approaches are employed to capture long-term changes in household structure and composition, household formation rules and patterns of leaving home in this historic Hanseatic community in two census years, 1819 and 1867. Overall, we can observe rather stable patterns for both the 1819 and 1867 censuses, with only small shifts away from more "traditional" towards more "modern" patterns of the family. Interestingly, the persistence of the family pattern in Rostock rested primarily on the continuity of nuclear family-centred patterns of co-residence. We were neither able to find evidence of a significant deterioration in the traditional pattern of the extended-family household, nor could we prove that a progressive nuclearisation of the family in Rostock took place between 1819 and 1867.
\end{abstract}

\footnotetext{
* Laboratory for Historical Demography, Max Planck Institute for Dermographic Research, Konrad-Zuse-Strasse 1, 18057, Rostock, Germany. Please address all communications to: Szoltysek@demogr.mpg.de and Gruber@demogr.mpg.de. We thank Martin Dinter (MPIDR) for his research assisstance, and for preparing datasets in particular, and Fred Heiden (MPIDR) for running six versions of the algorithm.
} 


\section{Introduction}

The classic theoretical wisdom, from F. Le Play up to the early 1970s, held that industrialisation resulted in the disintegration of the family group into smaller units of nuclear families. The supposed "structural fit" between the nuclear family and industrial society was particularly firmly established in the works of the structural-functionalist school. The nuclear family was thought to be best adapted to meet the demands imposed by the high rates of social and geographical mobility of individuals that was typical of the industrial system. In order to complete this adaptation, the family group must take a structurally isolated position in relation to more extended kin and neighbours, and kinship obligations towards the nucleus must take precedence over obligations to kin outside it. Accordingly, it was presumed that nuclear families will do better than extended ones in achieving the social and economic goals that characterise industrial society, and individuals living in nuclear family units will be better equipped to reach higher positions in life (Parsons \& Bales 1955; Goode 1966; Gore 1968; Sennett 1970; Smelser \& Halpern 1978). The nuclearisation thesis has been most simply summarised by Goode, who argued that "Wherever the economic system expands through industrialization, family patterns change. Extended kinship ties weaken, lineage patterns dissolve, and a trend toward some form of the conjugal system generally begins to appear" (Goode 1963, 6; see also Lee 1982, 114-119; for a general overview: Popenoe 1988) ${ }^{1}$.

Later research first undermined the hypothesis of the progressive nuclearisation of the family by suggesting continuity in nuclear family structure over many centuries, at least in Northwest Europe (Laslett \& Wall 1972). Some scholars went so far as to argue that particular developments in the West were attributable to distinctive family and demographic arrangements, and that the nuclear family along with the Western European marriage pattern were among the

\footnotetext{
1 The nuclearisation (or nucleation) thesis has also a parallel, but wider meaning within contemporary demographic discourse that is concerned with the development of family patterns in the non-European societies. It holds that a shift towards conjugal marriage and nuclear household residence patterns is an inevitable consequence of globalisation, specifically the penetration of Western-like socioeconomic developments, as well as Western ideology through formal education, Christianity and the mass media. Accordingly, evidence of increased conjugality as caused by those processes will also be reflected in the reduced symbolic importance of the lineage and ancestors, greater marriage stability, the demise of polygyny and widow remarriage, increasing age of first marriage for women, and decreasing age differentials between spouses (Neil and Neil, 1999).

Empirical research on industrialisation in contemporary developing nations provided at least partial support for Goode's theory of convergence (Goode 1963), where it has been shown that economic development is associated with a decline in family complexity. For example, two decades of rapid industrial and urban growth in Taiwan were accompanied by a well-documented decline in the proportion of extended households (Freedman, Chang \& Sun 1982). Similar examples regarding other Asian societies include: Wong 1975, Martin 1990; De Vos \& Lee 1993. Other recent studies, however, show the highly variable response of household and family characteristics to the processes of rapid socio-structural change (see McDonald 1992, 20-23; Ruggles 2009, 250-251).
} 
necessary preconditions for modernisation and industrialisation (Macfarlane 1978, 1987; Wrigley 1977; Laslett 1983; Hartmann 2004).

Still others, countervailing further structural-functionalist assumptions, argued that the harsh economic conditions of early industrial capitalism strengthened the interdependence of family members and led to a high frequency of complex households (Anderson 1971; Hareven 1978, 1982; Katz 1975). Laslett became himself involved in recasting this great historical debate, and suggested that it is increasingly possible to prove the reverse proposition about industrialisation and the structure of the household. He pointed out that, when some English communities are compared before and after industrialisation took place, "it can be shown that households became more, not less, extended" (Laslett 1973, 23; Laslett, Wachter \& Laslett 1978, 75-77). Wrigley speculated along similar lines, and argued that, indeed, the impact of industrialisation on the family may have been "anti-modern." During the early phases of industrialisation, the argument followed, people might find "a web of informal relations with kin and neighbours the only resort against disaster," which may consequently "produce changes in family structure and bahavior which appear regressive when compared with later changes" (Wrigley 1977, 82).

M. Anderson's study of family structure in 19th-century Preston, Lancashire (Anderson 1971) seemed to provide a prime empirical justification for promoting the view that the hardships of industrial city life might have actually stimulated the formation of extended households. Especially among young couples and the elderly, kin relations and kin support from within the household appeared to be highly functional in helping individuals to adapt individuals to the impact of the process of social change. Still, however, even in Preston, $73 \%$ of families were nuclear, and no more than $23 \%$ of households contained related persons other than members of the current nuclear family of the head (Anderson, 1971, 44).

T.K. Hareven's study on migrant families in the textile community of Manchester, USA, at the beginning of the $20^{\text {th }}$ century pointed in a similar direction (Hareven, 1982). Despite the development of industrial relations in the community, large and extensive family networks have existed among the migrants to the city. According to Hareven, this phenomenon may be explained by the fact that kin assistance was crucial in handling family crises and in coping with the insecurities imposed by the industrial system. Traditional functions of kin in rural society did not diminish, but were modified to fit the needs and requirements of urban, industrial life.

H.Medick (1981) looked at the problem from the perspective of developing subclasses of rural industrial producers. Referring to Mendels' classic proto-industrial thesis (Mendels 1972), Medick argued that, in some parts of Europe, the proto-capitalist period in the rural settings saw 
a rise in the number of proto-industrial producers whose links with the market economy made them an increasingly distinct socially and demographically from more traditional peasant classes. Working under the conditions of limited familial production capacity and high consumption pressures, such families have often found the formation of extended households a viable means of counterbalancing the poverty generated by the family life cycle. Such an extended family would function "as a private means to redistribute the poverty of the nuclear family by way of the family-and-kinship system," and would contain widowed or unmarried sisters or brothers, nieces and nephews "fairly frequently" (Medick 1981, 58-59; for similar arguments, see Scott \& Tilly, 1975).

D.Kertzer added yet another aspect to the discussion of the nuclearisation thesis. He found virtually no change in the co-residential pattern of the community of Bretalia in central Italy between 1880 and 1910, during which time that community began to be increasingly incorporated into the urban structure of neighbouring Bologna, and was undergoing a critical transformation of its socioeconomic and occupational structures. Interestingly, both before the urban expansion and in the midst of the modernisation-processes, some $42 \%$ of the people out there were living in complex family households. Despite nearly doubling the household and population numbers, the proportion of simple, as well as extended and multiple families, remained unchanged over the three-decade period. However, such an "uncanny similarity in coresidential situation," which took place irrespective of the process of socioeconomic change, undermined the nuclearisation thesis, leaving many other problems unresolved at the same time (Kertzer 1984, 91-97) $)^{2}$.

A. Janssens, who studied the Dutch industrial town of Tilburg between 1850-1920, also found a striking continuity in the overall pattern of living arrangements, despite the gradual but profound process of social change surrounding the town's families. Both before and during the period of rapid demographic and industrial developments in the town, a large majority of families in Tilburg followed a traditional pattern of co-residence, and developed a household structure beyond the nuclear core at some point over their cycle. In her empirical findings, Janssens suggested a model of social change in which family change is not directly and immediately linked to structural social change. According to Janssens, the Tilburg experience constitutes an example

\footnotetext{
${ }^{2}$ According to Kertzer, so little change in co-residential characteristics as revealed in the persistent attachement to living in complex domestic units over the entire period of socioeconomic transformation should be attributed to continual cultural elements perpetuating postmarital (joint) residence, together with strong normative pressure on the younger generation to provide for their ageing parents. These customs, although they evolved in response to entirely different set of economic conditions, continued afterwards under altered circumstances, because people found a way "to adapt patrilateral postesidence system to the problems (...) [they] faced in the new economic and social conditions" (Kertzer 1984, 105-106). Rapid population increase not accompanied by a concomitant increase in housing has also played a role.
} 
of the "cultural lag" that can exist between family systems and socio-structural developments (Janssens 1986, 1993).

By means of those studies, Kertzer and Janssens warned us that the effects of industrialisation on households and families may differ from community to community (Kertzer and Schaffino 1983; Janssens 1993). This line of reasoning was also followed by T.A. Arcury (Arcury 1990). He specified the factors affecting household and family characteristics during industrialisation, and argued that the nature of the pre-existing family system, the characteristics of the industry and its technology, demographic processes in the community, the relative poverty of the workers and availability of housing, along with socio-cultural characteristics of the population, may all affect the nature and direction of change in family system in a variety of ways (Arcury 1990, 286-287).

Other perspectives exist, however, adding to the theoretical confusion. S. Ruggles (Ruggles 1987), for example, challenged the proposition that the extension of the household structure served as a functional adaptation to the mode of industrial life by arguing that extendedfamily living arrangements in the 19th century were something of a luxury. They were far more common among the bourgeoisie than among the industrial working class. According to him, demographic change alone could account for visible signs of the rise of the extended family in the 19th century. He argued that increasing life expectancy and declining marriage between 1700 and 1900 greatly expanded the opportunities for living in extended families.

Such a proliferation of opinions proves that the scientific debate over the links between "modernisation" processes and the family structure has yet not come to an end. That the topic itself needs further elaboration is also suggested by the negligible number of studies on the issue for the German-speaking territories. Admittedly, H. Rosenbaum offered a very generalised overview of familial developments in 19th-century Germany, which, however, can hardly be translated into a more structurally defined notion of the progress (Rosenbaum 1996: 183-187, $476)^{3}$. What kind of trend in household changes can be expected within this cultural area can only be hypothesised on the basis of very scanty research. W.H. Hubbard's "GRAZHAUS-Projeket" from the 1970s, for example, used Austrian published census data from 1857, 1880 and 1900 to ask a related set of questions in relation to family developments in the city of Graz (Hubbard

\footnotetext{
${ }^{3}$ According to Rosenbaum, during the 19th century the bourgeois and proletarian families were introduced as new kinds of familial patterns. The proletarian families became important because of their numbers. There were fewer bourgeois families, but their ideals spread to other groups of the population. After 1830, the artisan families, particularly the richer ones, also took over bourgeois family ideals and separated themselves from their employees, which led to increasing numbers of journeymen living alone with their own families. The households of journeymen, and partly also those of poorer independent artisans, were increasingly similar to those of workers, while the households of richer artisans became increasingly bourgeois in style. However, there are almost no statistics in Rosenbaum's book, and especially not about household structures. For example, workers' families were mostly simple family households, but partly also extended family households (Rosenbaum 1996, 431).
} 
1976) ${ }^{4}$. Hubbard observed an increase in the number extended family households at the expense of simple family households in the second half of the $19^{\text {th }}$ century. Of the households in 1857 nearly two-thirds were simple family households, $22 \%$ were extended family households and about $12 \%$ were single-person households. In 1900, simple family households accounted for only one-half of all households, while extended family households made up about $40 \%$ of households, and the remaining 10\% were solitaries. Hubbard's research suffers, however, from some typological inconsistencies which prevent it from making fully useful comparisons with other datasets.

Crude data on mean size of private households available for some German towns may suggest something of a reverse pattern. In a trend that be indicative of a simplification of family structure MHS was found to have declined from 6.49 to 4.42 persons per household in Berlin between 1849 and 1867, and from 7.46 to 5.02 in Frankfurt am Main between 1840 and 1871. On the other hand, the data from Dresden and Leipzig shows no change in MHS over the 1849-1871 period (Rothenbacher 1997, 271-271).

This research attempts to reintroduce the problem of the relationship between a set of processes often subsumed under the label of "modernisation" and the family change to the historical-demographic literature by means of examining the impact of developing urbanindustrial life on the nature of the family system in the industrialising city of Rostock. We employ a variety of quantitative methodologies to capture long-term changes in household structure and composition, household formation rules, patterns of marriage and celibacy, as well as patterns of leaving home in the two censuses. The research is also motivated by a desire to provide some fresh insights into the effect of macro-level changes on micro-level processes involving the family. It is hoped that this newly available material might provide new empirical insights that will contribute to the further construction of theories regarding the interplay between processes of social change and family change in the past. This pilot study has the potential to uncover promising new research directions, due to the expected extension of the existing database to include two additional censuses from Rostock of equally high quality: the censuses of 1890 and $1900^{5}$. This new corpus of data may prove to be particularly meaningful. It will allow us to place co-residential patterns in Rostock in a much longer perspective that would cover the period during which the more critical alterations in the city's socioeconomic and institutional framework

\footnotetext{
${ }^{4}$ See also Hubbard 1984. Mitterauer 1976 looked at the effects of protoindustrial developments on the family composition, albeit in the rural setting only.

${ }^{5}$ Mecklenburg-Schwerin (Großherzogtum), Volkszählungsamt. Volkszählung am 1. Dezember 1890. Landeshauptarchiv Schwerin. 5.12-3/20 Statistisches Landesamt (1851-1945); Volkszäblung am 1. Dezember 1900. Landeshauptarchiv Schwerin. 5.12-3/20 Statistisches Landesamt (1851-1945).
} 
supposedly took place. Those processes would then be analysed in the context of broader demographic change, especially the onset and speed of the first demographic transition.

\section{Socioeconomic development and demographic characteristics}

A) There are significant reasons why the city of Rostock serves as a particularly suitable laboratory for re-evaluating existing models and theories regarding the relationship between developing urban-industrial life and the change in family system.

First, rich statistical micro-census data was gathered for this urban community of northern Germany between 1819 and 1867. These two dates mark two censuses carried out in Mecklenburg, and they offer valuable early data. The 1819 Census of Mecklenburg is one of the oldest surviving individual-level data population censuses in Germany. For the first time ever, the total population of Mecklenburg-Schwerin was quantitatively and qualitatively recorded ${ }^{6}$. Because of the wealth of information collected in the census of 1819 (sex, first name, last name, day of birth, place of birth, parish of birth, relationship to household head or occupation, property ownership, duration of residence, marital status, religion), this census is widely known for being a leading German population census of that time (Tscharnke 1943: 29). It was followed by the 1867 Census, which used modern refined population-counting methods, which were first implemented in Germany in the $1860 \mathrm{~s}^{7}$. Both censuses provide a wealth of information (an individual's name and surname, sex, year of birth, place of birth, social status, relationship to the household head, occupational and marital status, and religion), and, making certain allowances for the specificity of the 1819 data, can be used to conduct a structural analysis of the family system (see, however, certain reservations discussed below).

The socioeconomic structural development of the town during the $19^{\text {th }}$ century also presents an interesting context for the investigation into changes in its inhabitants' family and coresidential behaviour. Rostock was the biggest city of the Grand Duchy of Mecklenburg, and was home to around $5 \%$ of its entire population. Once a vital port town of the Hansa, sharing a

\footnotetext{
6 The census was ordered by the Grand Duke of Mecklenburg-Schwerin. The purpose of the census was to determine the exact military contingent of each Confederation territory. The lists were to constitute a "comprehensive register of every person living on the day of the census, as young or as old as they may be, of every gender, trade, or religion". Census enumerators were instructed to visit every household in order to list every person living in that household. The lists were due to be submitted by August 25th. However, taking the census took more time than expected, and the closing date was delayed to mid-November, and then again to early December. The last survey questionnaires were completed as late as in February 1820.

7 The 1867 census of the Grand Duchy of Mecklenburg-Schwerin was taken on the night of December 2-3, 1867. That night authorised enumerators visited every house in the district assigned to them, listing every person staying there at that moment in time. The head of each household was responsible for the correct completion of the census form. The census was taken based the rules used by the North German Confederation and the German Customs Union, which the Duchy of Mecklenburg-Schwerin became part of in 1867/68. The census was supposed to gain an overview of the taxable and conscriptable population.
} 
common maritime past with Hamburg, Bremen and Lübeck, it had recently experienced a centuries-long economic decline. At the beginning of the $19^{\text {th }}$ century, it was surrounded by agricultural land heavily characterised by manorialism and estate property patterns, but its city and private rights set the town distinctly apart from the rural hinterland. While serfdom was abolished in Mecklenburg in 1819, the right of abode was not granted until 1868, and freedom of trade was first declared in 1869 (Kuna \& Deya 2007). At that time, however, even the city itself still exhibited certain features of the pre-modern social and institutional order. It held on to its pre-modern municipal laws until 1871, which were replaced by the first unified German civil law code in 1900, bringing to an end the two-class system of "citizens" and "inhabitants" in the town (Reichsgesetzblatt 1874/ Nr 1019; Bundesgesetzblatt 1896; Reichsgesetzblatt 1896/ Nr 195). The dissolution of the guild system in Rostock did not start until 1871, and was finally accomplished in 1890 (Schröder 2003, 140). The social and occupational structure of Rostock at the end of the second decade of the 19th-century was classified as "pre-modern," as reflected in the high percentage of domestic servants, and the city was a prime example of a trading, commerce and service centre (Manke 2000, 210-212). The city's economy derived its identity from its longstanding maritime trading, with grain as its foremost trading good. Rostock's commitment to grain export was moved along by the agricultural structures of Mecklenburg's hinterland, and by the interests of manorial landowners, who ran large farms oriented towards grain production.

Nonetheless, the time between the censuses was marked by important structural developments which had considerable effects on the overall living standards of the city's population. From the mid-1840s onwards, compulsory school education was introduced, and the number of public schools increased from one in the $1820 \mathrm{~s}$, to seven in $1860^{8}$. The first railways had come to Mecklenburg in 1848, and Rostock was connected two years later. In 1873, the Friedrich-Franz Railway Company of Mecklenburg took up a regular schedule with the city (Mecklenburgischer Staatskalender 1880, 250-253). The introduction of steam engines marks another aspect of the general developmental trend. The Gieseler Register of known steam engines ${ }^{9}$ mentions four steam engines in Rostock for the time period before 1850: the first was the steam engine of the oil mill company Karnatz in 1823, the second was a machine in an ironcasting factory in 1838 , the third was in an oil mill in 1846, and the fourth was in a brewery in

\footnotetext{
${ }^{8}$ Among them: 1 Civil School of Higher Education -"Höhere Bürgerschule"; one "Industry School", as well as 4 for poor children). Source: Mecklenburgischer Staatskalender 1830, p. 143; 1840, p.196-197; 1850, p. 207; 1860 , p. 185 and 213 .

9 Gieseler, A. (2009). http://www.albert-gieseler.de/dampf_de/texte/impressum.shtml ; http://www.albertgieseler.de/dampf_de/tables/gsn1310.shtml.
} 
$1848^{10}$. Finally, the first bank for private savings was established in Rostock in 1825, and a second general bank was founded in Rostock in 1850 (Karge \& Münch 2004, 270-273).

Despite the turbulent socioeconomic changes discussed so far, Rostock was by no means a fully successful pioneer of industrial development. While during the first part of the $19^{\text {th }}$ century the city witnessed innovative developments, they were by and large hampered by prohibitive legislation of the time. The interests of manorial landowners from the hinterland had the effect of delaying incentives for industrial production and export in Rostock, other than that of grain (Manke 2000), a deficit which became more and more apparent in the second half of the $19^{\text {th }}$ century. The economic crisis of the 1820s, caused by overproduction of grain in Mecklenburg, heavily affected Rostock's shipping trade as well (Manke 2000, 199). The city regained its foothold in the second half of the $19^{\text {th }}$ century, and again entered a period of vigorous economic growth and modernisation. Profiteering from the Crimean War (1853-1856) between England, Russia and the Ottoman Empire help Rostock to recover. Grain shipments and transports of weapons into the war zone kept Rostock's merchant fleet busy, and led to a surge in transport profits of up to $240 \%$ (Schröder 2003, 135). What looked like opportunities for future long-term development soon, however, led to a stalling of structural innovation (with a distinct slump between 1850-1880), accompanied by legislative liberalisation.

Although the first iron steamship with propeller propulsion ever built came from a Rostock shipyard in 1851, this innovation did not continue. Instead, Rostock shipyards prolonged the construction of wooden sail ships. Not until 40 years later, when the merger of local ship sites created the great ship yard "Neptun" (almost exactly on the spot where the present MPI building is located), was the construction of steel ships initiated, and reached industrial dimensions (North 2008, 76). In contrast to cities like Hamburg, Bremen and Stettin, which had developed modern harbours with excellent transport connections, Rostock's docks were becoming increasingly antiquated; its harbour entrance was too shallow, and no investments in digging deeper shipping lanes were made. It became much more profitable, even for Mecklenburg crop farmers, to move goods directly by train to Hamburg (for shipping westward) or to Stettin (for shipping eastward), than to load ships in Rostock. (Karge \& Münch 2004, 135). ${ }^{11}$ The Prussian Railway line from Hamburg to Stettin, which cut across Mecklenburg, was set up in 1870, and added to the city's misfortunes (Karge \& Münch 2004, 135). Even though the next wave of steam engines arrived in Rostock during the 1880s, the city could hardly compete with

\footnotetext{
${ }^{10}$ The next wave of steam engines seemed to have arrived in Rostock only during the 1880 s, reaching a peak in the early $20^{\text {th }}$ century.

${ }^{11}$ In 1873, the Baltic harbor of Stettin had already handled 1,020,000 tons of goods, and Rostock handled 56,000.
} 
other centres like Bremen ${ }^{12}$. Last, but not least, Rostock faced serious difficulties in establishing itself as a developing financial market for the region. Despite being the largest city of the province, it only came in third in accumulating savings and investment capital during the $19^{\text {th }}$ century, ranking behind Schwerin and Wismar (Mecklenburgischer Staatskalender 1880, 274). ${ }^{13}$

\section{B) Demographic structures and developments}

The population in Rostock showed an almost steady increase the $19^{\text {th }}$ century, growing from 12,585 persons in 1800 to 82,401 persons in 1900. Part of this increase was due to a change in administrative borders in 1877 , which meant incorporating previously agrarian regions that had been urbanised during the previous decades (Figure $\mathbf{A}$ in the text $)^{14}$.

Figure A: Population growth in Rostock, 1795-1900

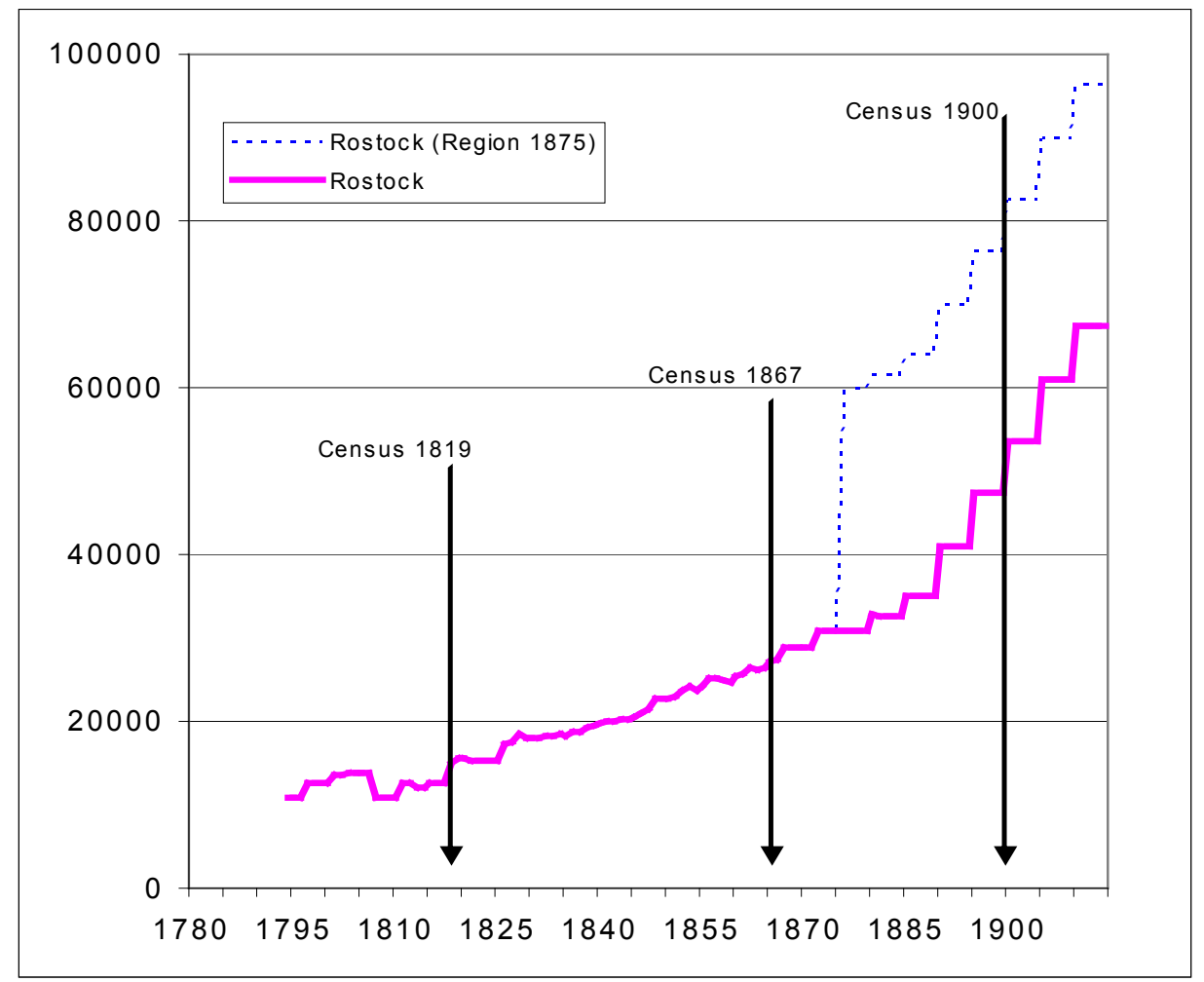

12 By 1910, Rostock counted 36 documented steam engines, most of them used by the shipping industry. Six additional engines could be found in nearby villages. For comparison: Bremen at the same time has documentation for 85 machines, but seemed to have entered the steam-machine era much later than Rostock, starting only in the 1860s.

13 It might be argued that this retarded socioeconomic development disqualifies Rostock as a suitable case for examining the relationship between industrialisation and the family systems. However, it has been argued that a classical industrial development characterised by dramatic and all-pervasive change associated with large-scale industrialisation should be considered as exceptional in historical reality. What the great bulk of the population in the $19^{\text {th }}$ century experienced was a social and economic change of a much more gradual and limited nature (Janssens 1993, 244-245)

14 All figures relate to our setting and data description, as well as to the research design that are pasted in the text, whereas those referring to the exact data analysis were moved to the Appendix at the end of the paper. 
The annual number of births consistently exceeded the number of deaths during each year of the $19^{\text {th }}$ century, with the exceptions of 1832,1850 and 1858, when three cholera epidemics took place. Crude birth rates were around 30, and crude death rates were between 25 and 20 . These rates provided for a steady and natural increase in the population, which was accompanied by a positive migration balance. Up to about the census year of 1867 , immigration was more important for population growth than natural increase, while afterwards natural increase became the leading force.

Figure B: Population age structure - Rostock in 1819 and 1867

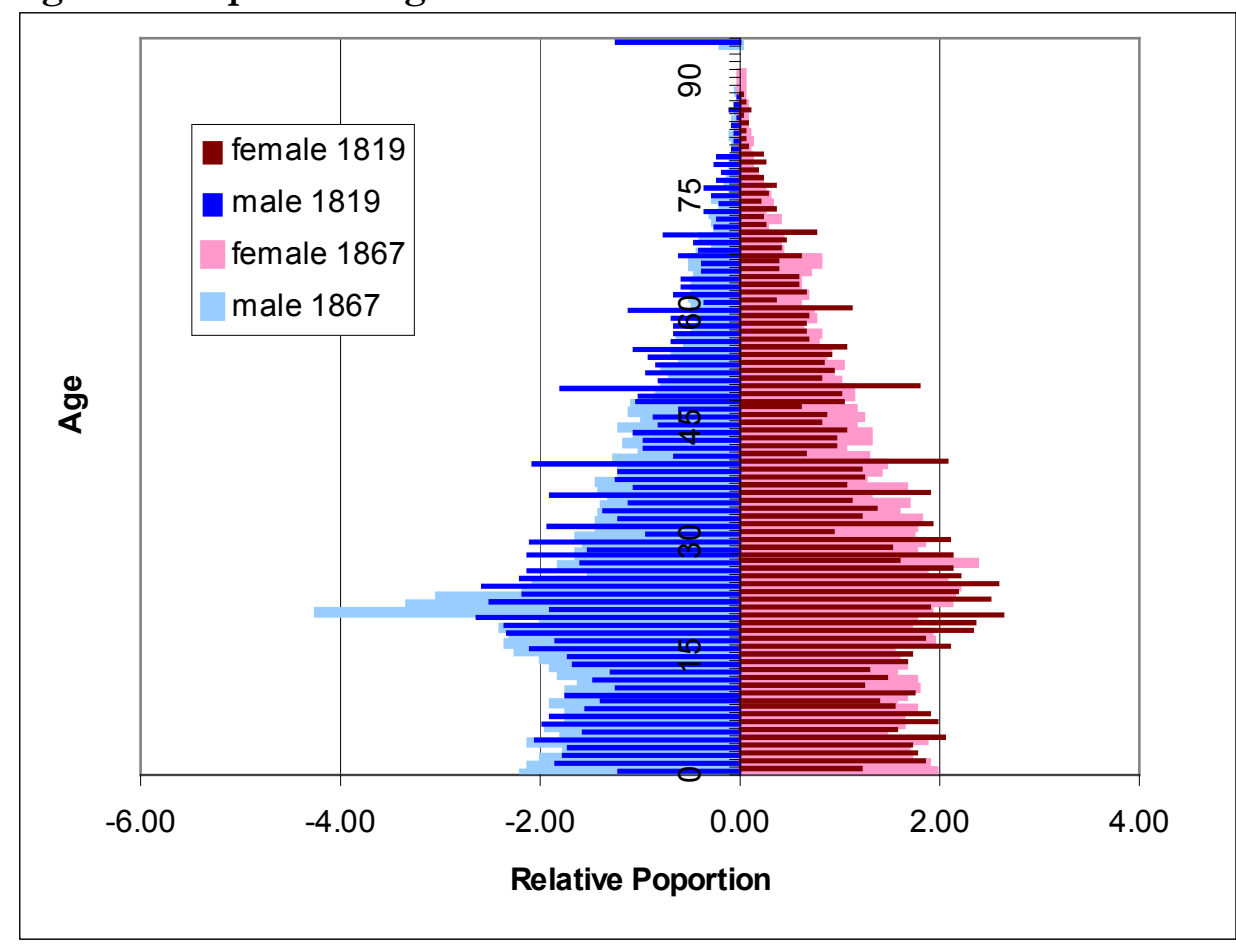


Figure C: Digit-specific modified Whipple's indices $\left(W_{\mathrm{i}}\right)$ and total modified Whipple's indices $\left(W_{\text {tot }}\right)$, males of Rostock 1819 and 1867

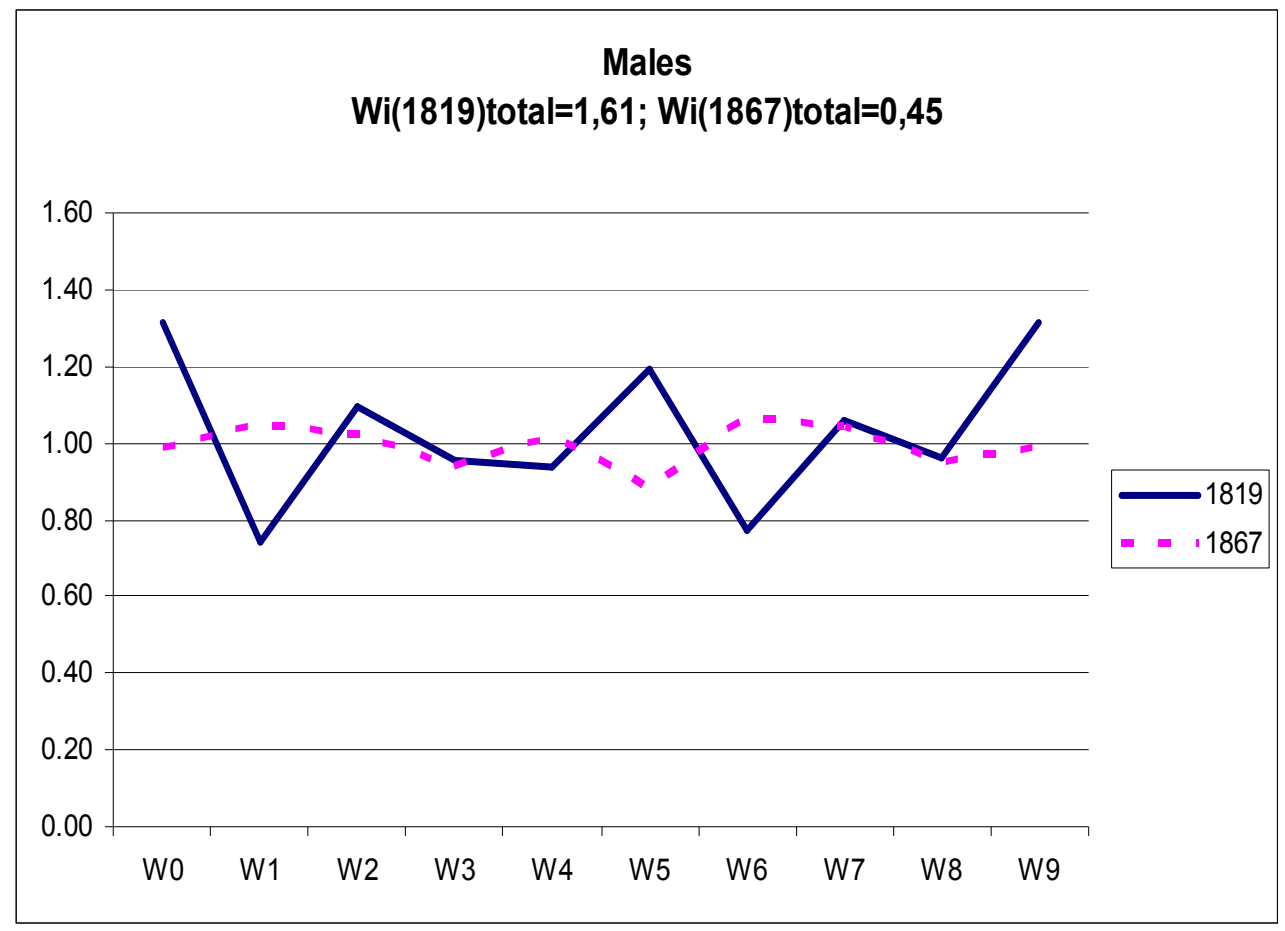

Source: Census data Mecklenburg-Schwerin for the city of Rostock

Figure D: Digit-specific modified Whipple's indices $\left(\mathrm{W}_{\mathrm{i}}\right)$ and total modified Whipple's indices $\left(W_{\text {tot }}\right)$, females of Rostock 1819 and 1867

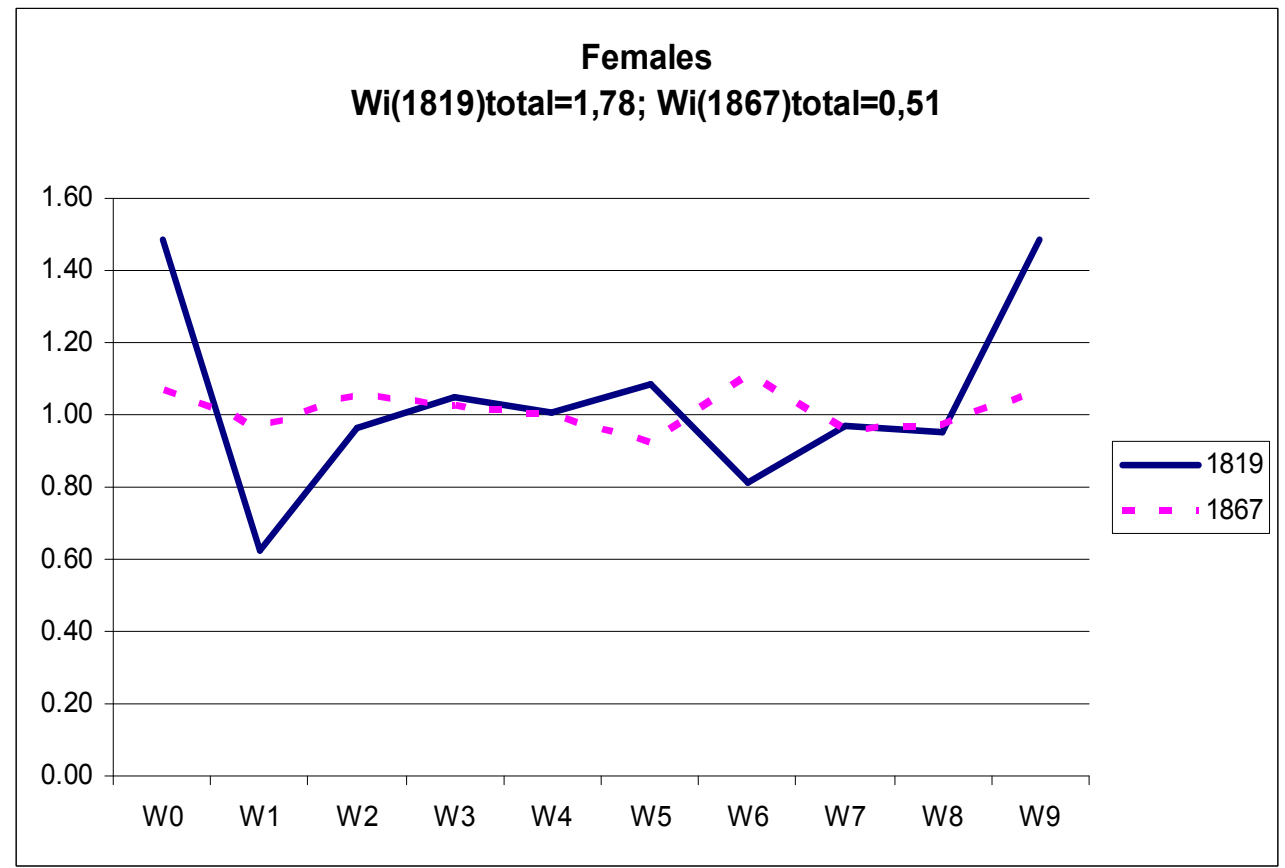

Source: Census data Mecklenburg-Schwerin for the city of Rostock 
The age structure actually takes the form of a pyramid, with the effect of immigration by young adults causing a bulge at around age 20 (Figure B). The extreme peak for men at this age is caused by the presence of many soldiers in the city in 1867 . We can also clearly see the effect of age heaping in the census of 1819, especially for women. The calculation of total modified Whipple's indices (Wtot) yields 1.61 for men and 1.78 for women in 1819, and only 0.45 for men and 0.51 for women in 1867 (Figures C and D) (on Whipple's indices, see Spoorenberg 2007).

The census of 1867, in conjunction with the numbers of burials in the new cemetery for the period 1865 to 1869 , allows us to calculate life tables for men and women (Table $\mathbf{A}$ in the text). The results are quite similar to those for the whole of Germany in 1871/80, but are much lower than those for the whole of Mecklenburg some three decades later, which had a much higher life expectancy rate than Germany as a whole due to lower infant and child mortality in the region. The infant mortality rate was between $10 \%$ and $25 \%$ for the years 1827 to 1875 , according to the church registers of the parish of St. Jacobi in Rostock (on urban mortality in Germany, see Vögele 1998).

Table A: Life table estimations - 19th-century Rostock in comparison

\begin{tabular}{|c|cc|cc|cc|cc|}
\hline \multirow{2}{*}{ Age } & $\begin{array}{c}\text { Rostock 1) } \\
1865 / 67\end{array}$ & \multicolumn{2}{c|}{$\begin{array}{c}\text { Germany 2) } \\
1871 / 80\end{array}$} & $\begin{array}{c}\text { Mecklenburg 3) } \\
1891 / 1900\end{array}$ & \multicolumn{2}{c|}{$\begin{array}{c}\text { Germany 2) } \\
1891 / 1900\end{array}$} \\
\cline { 2 - 9 } & $\mathrm{m}$ & $\mathrm{f}$ & $\mathrm{m}$ & $\mathrm{f}$ & $\mathrm{m}$ & $\mathrm{f}$ & $\mathrm{m}$ & $\mathrm{f}$ \\
\hline 0 & 35.58 & 38.73 & 35.58 & 38.45 & 47.14 & 49.87 & 40.56 & 43.97 \\
20 & 38.35 & 43.68 & 38.45 & 40.19 & 43.94 & 45.37 & 41.23 & 43.37 \\
40 & 24.57 & 28.45 & 24.46 & 26.32 & 28.10 & 29.48 & 25.89 & 28.14 \\
65 & 10.25 & 11.05 & 9.55 & 9.96 & 10.78 & 11.14 & 10.12 & 10.62 \\
\hline
\end{tabular}

1) Calculations by R. Scholz.2) http://www.lifetable.de/data/MPIDR/Germany1891-1900.txt3) Statistik des Deutschen Reiches. Neue Folge, Bd 200. Berlin 1910, S.32*-36*

\section{Research design}

\section{A) The family system and its main contributory factors}

We conceptualise the relationship between industrialisation and family relations as the former having an effect on the entirety or on some constitutive parts of the prevailing family system. The latter term requires some clarification. The concept of family system is one of the most frequently used in the studies of historical demographic structures (Laslett, 1983; Todd 1985). Unlike in classic anthropological works (where it usually refer to relatively well specified phenomena from 
the kinship domain; see Yanagisako 1979), in historical demographic research the family system has long remained ill-defined, and had been used to denote a wide variety of circumstances (see Wall 1991, 623; Berquo \& Xenos 1992). Recently, building on theoretical developments in the works of Wall, Hajnal, Laslett, Mitterauer and others, Polla (Polla 2006) presented a valuable definition of the family system concept. In line with Polla, we shall, when speaking of a family system, be referring to "an entity that comprises the household and marriage arrangements typical of a certain population at a certain time and all connected phenomena". In other words, the family system's main contributory factors include the household formation patterns, family forms, nature of the family life course, and marriage behaviour. Defined in this way, a family system is a social institution that changes with time, and its development 'depends on the combined effects of numerous external factors," including economic, social and ecological influences (Polla 2006, 28-29) ${ }^{15}$.

Here, we are taking a step beyond these theoretical considerations in an effort to grasp the very manifestations of change and development of family systems as precisely as possible. We suggest that the change in a family system can be effectively detected by observing structural developments in one of the domains listed below, or in several of them combined:

1) Marriage behaviour: A change in nuptiality may have a profound effect on other constituents of the family system. For most pre-industrial societies of Northwestern Europe, marriage was essentially linked with the process of household formation. Patterns of age at marriage and celibacy were also determinative of the joint co-residence of several conjugal units (Laslett 1977; Hajnal 1965, 1982; Seccombe 1990). In England, marriage behaviour strongly responded to short-term fluctuations in real wages. Towards the end of the $18^{\text {th }}$ century, women's mean age at first marriage fell drastically in line with the unprecedented increase in demand for labour caused by the Industrial Revolution (Wrigley \& Schofield 1981; also Schellekens 1997; King 1998).

2) Household structure: Despite older and more recent criticism of this assumption (e.g., Berkner 1975; Wilk \& Netting 1984; Sabean 1990; Wall 2001b), we find that changes and variations in the kin component of the co-resident domestic groups (that is, among persons sharing a clearly defined living space or dwelling; Laslett 1972), remain among the most powerful indicators of alteration and diversity in family systems. In a given community, the change in household structure (i.e., shift in proportion of nuclear households in relation to extended or multiple-family ones) may reflect significant changes in preferable or achievable residential patterns. It may also indicate a change in the way obligations toward kin from outside the

\footnotetext{
${ }^{15}$ Other valuable contributions to conceptualisation of the family systems include: Burch 1995; Wall 1995; Oris \& Ochiai 2002.
} 
immediate family circle are structured (Das Gupta 1997). Households that differ by structure may perform their welfare functions on a different basis altogether (Smith 1981; Cain 1991), and may cope with economic hardships in a different manner (Laslett 1988). Family systems with different dominant patterns of households structure may also generate dissimilar health and other developmental outcomes (Das Gupta 1999; Skinner 1997) ${ }^{16}$.

3) Household composition: Household composition (HC) is partly a derivative of household structure, but it carries a more complex set of meanings as well. Household composition is determined by all people living together and their relationships to one another. Therefore, the notion of household composition goes beyond the kin component of domestic group, encompassing the participation and roles of other potential household members, such as servants, lodgers and other non-relatives. Understood in that way, household composition provides more specific information on the character of family interaction, and reveals in much greater detail a certain form of organisation governing the transmission of practices and values within a domestic group (Goode 1964, 44-45; also Laslett 1983, 524-535). Since changes and differences in household composition may not always be fully reflected when household structure is scrutinised alone, household composition analysis allows us to discern a variety of more specific patterns within domestic groups, such as the size of the offspring and sibling group, types of co-residing relatives and types of relationships between all domestics (Wall 1977; Szołtysek, 2008a).

4) Household formation patterns: Our approach to this problem refers to two distinct but related phenomena. The first is a) the relationship between marriage and entry into headship (Hajnal, 1982, pp. 463 ff.). Under the Northwest European demographic regime, marriage and household formation usually went hand in hand: Men became household heads at first marriage, and entry into headship was concentrated into a comparatively narrow age range (Smith, 1981, 600). Any significant alteration in this sphere of behaviour points to critical changes in the overall structure of a family system, and has direct consequences on household structure and composition; i.e., on b) the tendency of adults in a population to head their own households or to share households (Burch et. al. 1987). This can be measured by either by the relative age-specific headship rates between the sexes (percentage of heads among the male and the female population of given age group), or, more sophistically, by computing a ratio of the actual number of households in a population to a theoretical maximum number of households that would result if each age-sex group in the population were to experience maximum headship rates (index of overall headship;

16 Examples of profound changes in the kin component of the co-resident domestic groups over time have been reported for such different settings as northern coastal Sweden 1700-1900 (Egerbladh 1989), French Haute Provence 1780-1836 (Collomp 1988), coastal Finland 1635-1895 (Moring 1993), central Belarus (Nosevich 2004), Hungary 1792-1804 (Andorka \& Balazs-Covcs 1986), and pre- and post-famine Ireland (Fitzpatrick 1983). 
Burch 1980). Changes in headship rates over time may be indicative of changes in household formation behaviour, either within age-sex marital status categories, or in the population in total. For example, a decrease in the value of age-specific headship rates over time may suggest increasing constraints on establishing an independent livelihood, or an increased trend towards "jointness" in residence among adults. Both trends would have clear implications for other elements of the family system (Burch et. al. 1987, 22).

5) Life course transitions of individuals: Since the lives of most individuals from historical populations evolved around household, individual life course transitions can be translated into changes in household position (Wall 1987, 82 ff). With the "synthetic cohort approach" commonly used with cross-sectional data, the life course household position of different age groups in the cross-section (measured by the relationship of individuals to the head of the household according to the individual's age and sex) can be assumed to represent a likely average experience of a real cohort passing through time, provided such a group of individuals can be followed longitudinally. Changes in the percent distribution of different positions within a given age group over time may, in turn, be indicative of changes in the timing of life course transitions, and/or of structural shifts in the sequence of roles an individual commonly passed through (Kok 2007).

6) Leaving home patterns: Leaving home patterns (LHP) constitute a special case of life course transition. Societies with different patterns of leaving home are often thought to represent entirely different family systems (Hajnal 1982; Reher 1998; Billari et.al. 2001), or to have different "life course regimes" (Mayer 2001). Changes in LHP reflect not just changes in the relationships between young adults and parents, but also different patterns of individualisation and of intergenerational solidarity. Since leaving the parental home for the first time is usually the first, and often one of the most significant migration decisions in the life course (Pooley \& Turnball 1997, 390), it is therefore often determinative of later sequences in the life course trajectories: of transition to marriage, headship and parenthood, and also of entering the labour market (Poppel \& Oris, 2004). Whether children left or stayed in the parental home depended on a variety of factors, including the production and income-pooling function of the domestic group, the gender of the children, the patterns of the labour participation of children, and regional labour market characteristics (Wall 1978, 1987; Bras \& Kok 2004, 423-429). This is why changes in the speed of the exit from the parental home are potentially revealing, both for tracing internal dynamics of the family life, as well as for placing these family developments within a wider socioeconomic context.

7) Residential patterns of the elderly: The living arrangements of the aged represent a particularly 
good indicator of intergenerational co-residence, and one which is less affected by variations in demographic conditions than household-level measures of family structure (Ruggles 2009, 252). Family systems may differ substantially in the way they perform their welfare functions for the most vulnerable members of the population (Smith 1981; Laslett 1988; Cain 1991; also Oris \& Ochiai 2002). This is particularly well reflected in the residential patterns of elderly people (Kertzer \& Laslett 1995; Dillon 2008; Szoltysek, 2008b). What position do the elderly find themselves in, and how does this change with urbanisation?

8) Service system: The existence of a specific pattern of life cycle service is commonly believed to represent a constitutive centrepiece of the eccentric northwestern European marriage and household formation pattern that ensured late marriage and the formation of a new production and consumption unit at marriage (Kussmaul 1981; Hajnal, 1982; Gates \& Hendrickx 2005). The circulation of youths helped to equalise the supply and demand for labour across households differentiated by wealth and stages of family life cycle (Dribe, 2000; van Poppel and Oris, 2004). Domestic service, as well as apprenticeship, facilitated the accumulation of savings for the establishment of new households, and was also believed to promote economic growth in Western Europe, where it was supposed to strengthen "acquisitory impulses" along with “individualistic" behaviour (Macfarlane, 1978; Hartman, 2004; Fauve-Chamoux 2004). Since in the European past, servants and apprentices were commonly treated as household members, changes in the incidence of this substantial stratum, as well as in the latter's demographic profile, encapsulate important structural shifts within a given family system. Despite having been an essential institution in early-modern England, life-cycle service slowly died during the transition from a pre-industrial to a fully industrial economy (Cooper 2005).

\section{B) Other methodological considerations}

Before presenting the results of our investigation, some additional remarks on matters of methodology are necessary. Normally, the eight main constituents of the family system discussed above can be meaningfully analysed with the use of cross-sectional census data ${ }^{17}$. However, since we are analysing changes in household structures over time using two separate population censuses, a constant effort had to be made to ensure that we are comparing actually the same unit called "household." Even slight differences in definitions of a household will yield different data (Schmid 1988, 14). In this regard, despite the relative wealth of material that was available to us, we faced certain difficulties. Whereas the census of 1867 featured borders between households that were clearly assigned during the process of collecting the census data, the census of 1819

17 Note, however, Ruggles' remarks regarding sensitivity of household-level measures to demographic conditions (Ruggles 2003). 
delineated no such household borders in the census manuscripts. The 1819 census is a list of inhabitants, with no clear designation of where one household ends and where a new household starts. There is also no information about the addresses of the people in the census manuscripts.

How can we cope with these data insufficiencies? Do they rule out the achievement of our research goals? Is it possible to invent a realistic and meaningful way to delineate households in the 1819 census? A household has been defined by Laslett as a co-resident domestic group, as a "series of names of individuals in blocks, with clear indications of where one block ended and the next began" (Laslett 1972a: 24). This co-resident domestic group has three basic characteristics: The members of the group sleep under the same roof, share a number of activities, and are related to each other by blood or by marriage. In addition, the group may occasionally include non-related persons—-like servants, visitors, boarders, or lodgers—as members of a household (Laslett 1972a: 25). Later definitions presented by R. Wall concentrate on the first two characteristics (Wall 2001b). Households are similarly defined in contemporary demographic discourse (Schmid 1988, 14-15; Ermisch 1988, 23-26). The apparent straightforwardness of the definitional approach notwthstanding, extracting household data from historical micro-census counts can be a complicated and confusing task. The extreme difficulties we faced are similar to the difficulties faced by other scholars working in the field (Berkner 1972, 1975; Hammel 1984; Hammel \& Wachter 1996a, 1996b; Sovič 2008).

Interestingly, in a published version of the Rostock census of 1819 based on a database which has been created for historical research, the city's population is represented by households (Manke 2005). These "households" were "created" during the data entry of the census based on the characteristics of a person's last name, marital status, sex, property, relationship to household head and occupation (Manke 1997: 131). A household defined in this way would contain the nuclear family of parents and unmarried or economically dependent children, co-resident relatives, personnel (domestic servants, employees) and other persons (e.g., boarders and lodgers) (Manke 2005: 18). The basic criteria for being a head of a new household were the following:

- being adult,

- having no relationship to a member of the previous household or family, and

- having no immediate dependent employee.

Another decisive factor for heading a household was having an income while not being a live-in employee like a servant (project documentation). Manke states that this was relatively unproblematic (Manke 1997: 131, endnote 12), but later he is more sceptical about the effect of 
the absence of household borders (Manke 1999: 651; Manke 2005: 458). In a book about the city of Rostock between 1750 and 1850, he again downplays this problem (Manke 2000: 346).

Although the rules might present themselves as relatively straightforward, they actually led to an overcounting of the number of one-person households, very often lone elderly people (Table 2; 1819 File A). This fact was recognised by Manke, but was not considered a problem (Manke 2000: 19, 346). As a consequence, people who lived in a poorhouse or were soldiers were treated as individual households in this file, and also in the published edition of the census. This is why a second file was created, which allowed for the creation of institutional households and the inclusion of more people into the previous households. The factor of having an income was considered in a more restricted way, and therefore fewer persons qualified for heading an independent household (see 1819 File B in Table 2).

In the next stage, we decided to test the quality of both files with an algorithm that creates households according to a strictly defined set of rules ${ }^{18}$. The census of 1867 , which was not affected by the definitional problems discussed so far, was taken as our reference point for designing such rules of assigning people to household units and for assessing the appropriateness of the algorithm's fit to the "real" data structures. Artificial household structures simulated along a common set of rules for both the 1819 and 1867 censuses have yet another advantage. By imposing standard scenarios of household membership on undifferentiated groups of individuals in both enumerations, we hoped to approach a required comparativeness of two datasets more effectively ${ }^{19}$.

Our algorithm exercise was a two-fold process, which went back and forth between calculation and the thorough comparison of real and simulated structures. We conducted a number of experiments using various scenarios for assigning individuals to domestic groups, with the goal of obtaining the most satisfactory match with the 1867 census, and, if possible, with the 1819 census as well. After several modifications, our household membership rules came to consist of the following principles ${ }^{20}$ :

18 We thank Josh Goldstein (MPIDR) for directing our attention to these possibilities for overcoming the deficiencies of the 1819 census.

19 Our optimism is, however, strongly limited in this regard by the fact that more information is missing in the census of 1819 than in the census of 1867 . In the earlier census, only $41.2 \%$ of males and $77.7 \%$ of females have an entry for relationship to household head, compared with $92.9 \%$ of men and $93.3 \%$ of women in 1867 . The percentages for occupational titles are likewise lower for men $(66.2 \% / 79.2 \%)$ and women $(26.6 \% / 40.1 \%)$ in 1819 than in 1867.

20 The first assumption for dealing with this problem is that the members of a household were registered consecutively. According to Manke, this procedure is confirmed by other scholars (which ???) ${ }^{20}$, although the German Customs Union (Deutscher Zollverein) obliged its member states to count the population according to households only in 1843 (Manke 2005: 457). The order of the persons within a household was not always a sequence like household head/wife/children/servants (Manke 2005: 458), and therefore the algorithm could not be built upon such a sequence. 
- a person belongs to the previous household if

- the family name is the same,

- the occupational title belongs to a list of occupational titles indicating co-residence (e.g., servant, apprentice, journeyman) and the person is unmarried,

- the relationship to the household head indicates this,

- the occupational title is the same as the previous one and the person is not married,

- the person is absent at the time of the census,

- there are indications that the person belongs to an institutional household (e.g., poorhouse, home for the mentally ill)

- the person is unmarried and below age 20,

- the person is an unmarried woman below age 25,

- there is no information about the relationship to the household head and no occupational information,

- the person is a married woman and there is no information about the relationship of the person to the household head, or

- the person is an unmarried woman between the ages of 20 and 39 and there is no occupational information about her.

Table B presents the results of the algorithm, which are quite fine for the file of the 1867 census for the first two measures, but are much less satisfactory for the overall measure of complete matches of households. The 1819 files have results which reflect the number of households: The larger number of households in File A leads to a higher number of household heads who are not found by the algorithm, and a lower number of additional household heads created by the algorithm. The overall fit is better for File B. Better still, we can be sure that more than $80 \%$ of all households in all files are defined correctly, and thus for most of the results there are only minor effects of using different household limits. 
Table B: Results of the algorithm, Version 5

\begin{tabular}{|l|r|r|r|}
\hline Census file & 1819 file A & 1819 file B & \multicolumn{1}{c|}{1867} \\
\hline Number of households & 4,098 & 3,601 & 6,826 \\
\hline Number of households according to algorithm & 3,924 & 3,924 & 6,715 \\
\hline Household heads not found & 364 & 143 & 491 \\
\hline Percentage & $8.9 \%$ & $4.0 \%$ & $7.2 \%$ \\
\hline Household heads found in both files & 3,734 & 3,458 & 6,335 \\
\hline Percentage & $91.1 \%$ & $96.0 \%$ & $92.8 \%$ \\
\hline $\begin{array}{l}\text { Additional household heads created by the } \\
\text { algorithm }\end{array}$ & 190 & 466 & 380 \\
\hline Percentage & $4.6 \%$ & $12.9 \%$ & $5.6 \%$ \\
\hline Complete matches of households: not matched & 774 & 642 & 1,145 \\
\hline Percentage & $18.9 \%$ & $17.8 \%$ & $16.8 \%$ \\
\hline
\end{tabular}

Still, however, we thought more elaboration was needed to make the final decision about which of the 1819 files is more suitable for comparative statistical analysis. This is why, in the second step, we focused on assessing the effects of the algorithm on household structures, and compared household types of all three files with the typology of the households simulated by the algorithm. As can be seen from Table $\mathbf{C}$, there is almost no difference between real and simulated household structures for the 1867 census. The only minor difference is a slight increase in the number of solitaries at the expense of simple family households.

The algorithm for the census of 1819 resembles File B to a much greater extent, with the exception of solitaries (relatively similar proportions of nuclear and extended families, along with almost absolute sameness of results for other types of domestic groups, seem to be critical here). Nonetheless, the observed mismatch of data for solitary households between simulated files and groupings from 1819 File B has two implications. First, since we know that the algorithm generally overcounts the number of solitaries and undercounts the number of simple households by approximately $2 \%$, we may think of the discrepancy between the two files as being a little bit smaller than is suggested ${ }^{21}$. On the other hand, our knowledge of the literature and the existing datasets lead us to believe that the proportion of solitaries in the 1819 File A is too high. Litchfield's study of 19th-century cities found only one case in which the share of households of people living alone or with non-kin only was $18 \%$. All the others had lower percentages (Litchfield 1988; also Reher 1987). The highest proportion of solitary households ever registered comes from the 1802 census of Rheims, where they constituted 19\% of all domestic groups (Fauve-Chamoux 1983, 481; see also Duben \& Behar 1991, 41). The high proportion of solitaries

\footnotetext{
21 Another factor contributing to different results of the algorithm for both censuses can be related to the larger amount of information missing in the census of 1819 than in the census of 1867.
} 
in File A would exceed all these examples by far. This is the rationale behind our decision to use 1819 File B rather than File A for all subsequent tabulations presented in this paper.

Table C: Comparison of percentages of household types

\begin{tabular}{|l|r|r|r|r|r|}
\hline & 1819 File A & \multicolumn{1}{|l|}{$\begin{array}{l}\text { 1819 File B } \\
\text { Algorithm 5 }\end{array}$} & $\begin{array}{l}\text { 1867 File } \\
\text { Algorithm 5 }\end{array}$ \\
\hline 1 & 27.4 & 17.4 & 25.6 & 17.8 & 19.9 \\
\hline 2 & 5.4 & 2.0 & 2.4 & 2.7 & 2.7 \\
\hline 3 & 53.4 & 75.3 & 67.7 & 71.1 & 68.4 \\
\hline 4 & 13.5 & 5.1 & 4.2 & 8.3 & 8.6 \\
\hline 5 & 0.1 & 0.1 & 0.0 & 0.1 & 0.0 \\
\hline 6 & 0.2 & 0.2 & 0.2 & 0.8 & 0.3 \\
\hline $\mathrm{N}$ & 4,098 & 3,601 & 3,924 & 6,826 & 6,715 \\
\hline
\end{tabular}

Note. Type 6 includes institutional households.

\section{Family system in Rostock: Comparison of 1819 and 1867 micro-census data}

\section{Marriage}

Age at first marriage was high, and remained relatively stable over the entire period under investigation. Men married at an average age of 30.5, and women at an average age of 27.7, according to the marriage registers of the parish of St. Jacobi for the years 1863-1872 (no. of records?). The Singulate Mean Age at Marriage (SMAM) yields similar results: ages 30.5 and 27.4 in 1819, and ages 30.3 and 28.2 in 1867 . However, the proportions of the never-married in various age groups reveal important compositional shifts (Figure $\mathbf{1}$ in the Appendix). Up to age 30 , there were no differences in the percentages of unmarried people in different age groups between the two sexes in 1819 and in 1867. The only exception here seems to be the arrestingly high quota of celibates among males aged 20-24 in the latter census, caused by the presence of large numbers of unmarried soldiers residing in the city in 1867 . The only important change took place among middle-aged males (age group 30-49). In both censuses, the shift from age group 2529 to 30-34 was marked by an approximately 65\% decrease in the quota of unmarried males. But male entry into the marriage market was much faster in 1867 than in 1819, indicating that marriage opportunities for men in these age groups had improved. For women, the reverse pattern can be observed: After the age of 34, constraints on female marriage seemed more apparent in the 1867 data than in the data from 1819. This differential nuptiality behaviour of middle-aged females in the two censuses also seems to have had longer-term consequences. In the age group $50+$, the number of celibate women was still higher in 1867 (16.26\% to $18.95 \%)$. 
Despite these changes in the middle and later stages of the life course, the marriage patterns were rather similar during the period between these two censuses.

\section{Household structure}

Nearly three-quarters of all households in 1819 in Rostock were of a nuclear structure, and all other types of domestic groups other than those of solitaries appeared in only negligible numbers (Table 1 in the Appendix). The cumulative percentage of all complex households (extended and multiple-family together) only slightly exceeded $5 \%$. Out of almost 4,000 households, only five displayed a multiple-family structure. Such structural distribution of household types in Rostock pertains to the prevalence of a strictly nuclear family system in the city, also characterised by a significant share of solitary households ${ }^{22}$.

The comparison of those figures with data from 1867 reveals only minor shifts in the proportions of different household types between the two censues. First, there was a $\operatorname{sight}(4 \%)$ decrease in the proportion of nuclear families, which was paralleled by a comparable rise in the share of extended ones. Although the number of the latter nearly doubled in relative terms, the 1867 census still featured only a very small proportion of households with extension, generally smaller than in pre-industrial and industrialising England (Laslett, Wachter \& Laslett 1978, 70-72; Laslett 1977, 21-21) ${ }^{23}$.

The discussion of proportions of different types of households can be further supplemented by looking at the overall percentage of domestic units containing co-residing kin other than offspring. Since our category is now more inclusive (apart from extended and multiple-family units, it also includes households of Laslett's Type 2), we end up with slightly higher figures than before. In 1819, households with kinsmen beyond the nuclear family constituted $7.10 \%$ of all units, while their respective share in 1867 was $11.29 \%$. Here, the general direction of change among households with kin co-residence is confirmed, whereas the percentage change between the censuses is only slightly larger than if we look at extended and complex families alone (3.23\% to 4.19\%). All in all, however, figures for both 1819 and 1867 contain significantly less complex households than in mid-19th-century Preston, where $23 \%$ of all households contained related persons other than members of the conjugal family (Anderson 1971, 44).

The comparison of the "real" data in Table 1 also demonstrates the stability of the pattern among solitary households over time. However, keeping in mind all reservations

\footnotetext{
${ }^{22}$ By solitary households, we mean here domestic groups headed by solitary persons, and not the single-person households.

${ }^{23}$ Laslett proposed the figure of $10.1 \%$ extended households for pre-industrial England. In the city of Rotterdam, extended families varied from 6\% to 13\% between 1810 and 1880 (Janssens 1986, 29).
} 
expressed so far regarding the data structure of 1819 census, we have to be careful not to assign too much importance to this observation.

The structural distribution of simulated households generally confirms trends already detectable in the real data, with only minor shifts in comparison to the latter. It points to only a very small change in the overall household structure pattern in the city over time. Although the rise in co-residence with kin (as revealed by proportions of households Types 4-5) somehow manifests more strongly among synthetic households (a change of $4.5 \%$ ), the overall change remains small, and final levels of households complexity are still below the English standard (Laslett, Wachter \& Laslett 1978, 71). Again, the suggested change over time in the propensity to live alone must be viewed with caution.

In general, if we assume that the socioeconomic changes that were taking place in Rostock between 1819 and 1867 had an effect on prevailing household structures, we must conclude that both observed as well synthetic changes in the household pattern are rather trivial. The question of whether our observation of change in co-residence with kin can to be seen as supporting Anderson's “adaptation” hypothesis is disputable. Indeed, the change occurs in the predicted direction, but the magnitude of that change seems to be too small to prove the hypothesis.

If the observed increase in extended family households is not artificial ${ }^{24}$, then it could be seen as an effect of changing residence behaviours, a change in the relative proportions of groups within the urban population showing different residence behaviours, or an alteration in other demographic parameters, such as increasing life expectancy. We do not yet have enough information to research these possible reasons for this increase.

To get a better sense of possible changes in household structure patterns between the two censuses, we analysed the dynamic features of household organisation in 1819 and 1867 (Figures 2-5). The figures reveal a rather well-marked pattern of changes in family composition over the age of household head. In general, patterns for 1819 and 1867 are more or less compatible, both with regards to real and synthetic data. As expected, we found that the incidence of nuclear households predominated throughout the entire life cycle, except among the youngest heads. In all datasets, over $80 \%$ of male heads aged 25 to 64 were heading nuclear households. The only slight difference in the life-cycle pattern of nuclear families over time seemed to occur at older ages in 1867, in which the increase in co-residence with relatives smoothed the otherwise quite precipitous decrease in the proportion of simple family households relative to 1819 . The most

\footnotetext{
${ }^{24}$ It cannot be ruled out that the increase in the proportion of extended households in both tabulations could be artificial: Since the 1819 census provides less detailed kin relationships within domestic groups, it may be that some of those from the pool of solitaries might have actually been co-residing kin in 1819.
} 
significant difference found between 1819 and 1867, which is confirmed by both real and simulated data, is a large increase in the share of solitary households among the youngest heads (aged 15-19 and 20-24). This trend is only to a limited extent accompanied by a rising tendency to head solitary domestic groups at later ages. In the 1819 real data, 56.3\% of the cumulative number of youngest heads (aged 15-24) were heading solitary households, whereas in 1867 this proportion increased to $86.8 \%$. Synthetic household data yield even more striking evidence of that change (respectively, $56.9 \%$ to $91.3 \%$ ). These patterns signal that some important shifts were taking place in Rostock between the censuses. First, the link between entry into marriage and entry into headship must have weakened over time. This, in turn, may be indicative of increasing opportunities for young people to form independent households and to cope with all the difficulties associated with heading them without support from immediate kin. The observed change also suggests the growing importance of households devoid of socialisation functions. All in all, we hypothesise that such a significant increase in the proportion of solitary households among younger heads represents an important departure from more "traditional" household lifecycle patterns. To some extent, this may be indicative of the emergence of a new sequence of life course transitions within some segments of the population: leaving home and becoming the lone head of an independent household (with or without other non-related co-resident people), and then establishing a nuclear family household at or after marriage. This small fraction of the city's male household heading population (1.4\% in 1819 , and $2.3 \%$ in 1867 ) may then be assumed to represent innovative behavioural patterns ${ }^{25}$.

The numerical importance of particular household types among the populations under study can be better understood if we infer the intersection between individual and household life patterns from the age structure by household membership (comp. Lee \& Gjerde 1986, 94-95).

Figures 6-9 provide estimates of the proportion of the entire population found in various types of households separately for 1819 and 1867, and separately for real and synthetic data.

All the datasets show that the overwhelming majority of children below age 15 (more than $80 \%$ ) spent their childhood and early teenage years in nuclear households. A slight rise in the share of population living in extended households over time represents another pattern, which is otherwise very stable across all age groups in all datasets ${ }^{26}$. Thus, living with relatives cannot be attributed to any specific age group of the city's population in either 1819 or 1867 . By contrast, live-in solitaries had a more pronounced life-cycle pattern: In all datasets, this situation

\footnotetext{
25 This seems to be partly confirmed by the data on home-leaving patterns presented later in the text. At this stage, more detailed characteristics of this group cannot be provided. However, it may well be that some of them were part of the immigration to Rostock from the neighbouring rural areas.

${ }^{26}$ Although the share of population living in extended families tripled in absolute terms (from 1,119 to 3,442), the relative change was much less pronounced (7.36\% to $12.10 \%$ of total population $1819-1867)$.
} 
mostly occurred among young adults and elderly people. The only subset of the population who seemed to be strongly affected by this life-cycle change were the aged. The direction of change among the elderly is, however, represented differently in the original and in the synthetic data. Although the former suggests a decrease in the proportion of the elderly aged 65 and older living in nuclear households, and an increasing tendency among the elderly to live in extended families, older people were most likely to live in solitary or no-family households. Whereas the synthetic data point to the same pattern regarding living in households with kin, the data also suggest a significant decline in solitary living among the elderly over time. Currently, we have no sufficiently refined methodological tools to solve this problem. However, assuming there is a tendency for the algorithm to multiply the number of solitary households in older age groups in the 1819 census, we tentatively suggest that a moderate rise, rather than a decline in living in solitary households, more accurately represents the real development over time.

\section{Household composition}

An analysis of household composition in Rostock provides a more detailed view of the internal dynamics of family systems between the censuses. First, there was no detectable change in the mean number of residents per domestic unit between the 1819 and 1867 censuses. Both in 1819 and in 1867, an urban household in Rostock had around four persons on average ${ }^{27}$. Equally, almost no change is revealed when we look at the mean experienced household size (5.95 to $6.05)^{28}$. Furthermore, no distinguishable trend is visible when the focus is on "houseful," which is defined to include inmates, lodgers and other co-residing non-kin (4.28 in 1819 to 4.21 in 1867).

Various measures of household size can, however, still be too crude, and they may still obscure important compositional shifts among different subsets of the population and groups of households. By looking at the proportion of people living in households with different sizes in 1819 and 1867, the occurrence of compositional shifts in the population can be investigated (Figure 10). When real data from 1819 and 1867 are compared, however, the proportions of people living in households consisting of 1-3, 4-6, 7-9 and 10+ persons are found to be basically identical in both enumerations. Similar stability is revealed when the proportions of households of different sizes in both censuses are scrutinised (Figure 11). This picture is generally corroborated by the synthetic data. In this regard, the only more pronounced difference concerns proportions of households with 1-3 persons. The probable cause of this finding can, however, be

\footnotetext{
27 MHS is here defined according to the rules suggested by Laslett 1972b, 133. It encompasses members of core families, their co-resident kin, together with servants attached to the household, but excludes inmates, lodgers and other non-kin.

${ }^{28}$ See Halpern 1972, 409 for a definition.
} 
related more to the artificial increase in solitary households due to the working of the algorithm on the 1819 data, than to the real trend.

More details regarding the internal composition of households in the two censuses are presented in Table 2, which focuses on two groups of co-residents: offspring and relatives. Basically, there is a striking stability in the pattern over time among offspring. A slight increase in the overall percentage of co-residing relatives in the population corroborates our previous observation regarding the increase in propensity towards co-residing with kin that took place between the two censuses. On the other hand, however, the change in the mean number of relatives per household was shown to be almost negligible (0.09 to 0.14), suggesting that, at the level of an "average household," the degree of change was trivial.

A more detailed overview of the types of co-residing kin and the change in their respective shares in the total population is given in Table 3. These data suggest that the slight increase in co-residence was caused equally by a rise in co-residence with parents, as well as with lateral kin of other kinds. We still do not know whether this was caused by a changing pattern of co-residence, transmission of property, increasing care for the elderly, or simply increasing longevity in the case of parents. All in all, however, the numbers here are very small. More important is the fact, that in both censuses, almost one-quarter of the city population was made up of persons not related to the respective household head (servants, lodgers, and other nonkin $)^{29}$. This likely demonstrates that the traditional pattern of servants or other employees, such as apprentices, living with their employers still existed far into the $19^{\text {th }}$ century in Rostock.

\section{Household formation patterns}

With Figure 12, an attempt is made at examining changes in age-specific headship rates over time. Since female patterns of headship seem to be highly sensitive to procedures for setting up borders between households through the algorithm, we focus here on male population only.

Two issues stand out. First, the match between real and synthetic data is almost perfect, particularly for age groups up to 40-44. More important, both real and synthetic datasets seem to be identical in terms of male household formation patterns. For men in both 1819 and 1867, headship rates rose steadily up to age 35 . After that, the process continued, albeit at a much slower pace, leading finally to peak values of male headship among men aged 44-54. Only then can a discrepancy between the 1819 and 1867 censuses be observed (though still of a rather small magnitude). For example, in the age group 50-54, only $2.6 \%$ of men were not heading

\footnotetext{
${ }^{29}$ Some of them may actually have been relatives, but they are recorded in the census manuscripts under their occupational relationship to the household head, and not their kin relationship.
} 
households in the 1819 census, whereas corresponding proportion of men in 1867 had more than doubled $(=6.2 \%)$. The difference disappears, however, in subsequent age groups.

But what really matters in understanding the very process of household formation is the actual relationship between marriage and entry into headship (Hajnal, 1982, 463 ff.). Data pertaining to the understanding of this important link is shown in Figure 13 (real) and Figure 14 (synthetic). The overwhelming majority of those who married at around 1819 also became heads of households, either at marriage or shortly thereafter. In other words, for the population of the earlier census, the entry into marriage was essentially linked with household formation ${ }^{30}$. This link between marriage and entry into headship had weakened by 1867, particularly for adult males. Even though, after the age of 34 , there was a continuous increase in the proportion of evermarried men, this was trend no longer accompanied by a similar pace of entry into headship. In the age group 35-39, 98\% of married males were also heading independent households in 1819, whereas in 1867, the respective figure was only $94 \%(6 \%$ of ever-married men at this age were not heads in 1867, compared to $1.7 \%$ in 1819). Only among the elderly males aged 65 and older do the 1867 figures converge with earlier census data.

On the other hand, in both censuses there has always been a small fraction of men who were heading their own households despite having never been married (approximately 4\%-7\% of all males in respective age groups). The patterns of changes in this interesting phenomenon over time are better illustrated on a single chart with two dashed lines (Figure 15) ${ }^{31}$. Drastically discrepant patterns among younger heads between 1819 and 1867 must be attributed to the steady development of the city's university, and the related significant influx of young adults occupying independent households. By the age of 30, much of the difference between two populations had disappeared, paving the way, however, for a consistent decrease in the proportions of never-married heads among adult males between 1819 and 1867.

\section{Life course transitions of individuals}

Figures 17-20 show the changes in an individual's position in the household as measured by the relationship to the head of the household, according to the individual's age, sex and the census year $^{32}$. These patterns of male life course positions in the household in both censuses are in line with most of the observations already made. Up to the age of 20 , the two listings are almost indistinguishable. After that point, the numerical importance of children as co-residents

\footnotetext{
30 The overall mean difference between percentages of ever married males and ever married heads in all age groups, was minimal, and was equal to $1.64 \%$.

31 The basic pattern from Table 15 is to a large extent replicated with synthetic data in Figure 16.

32 Since original and synthetic data were almost identical for 1819 and 1867, only the former is displayed.
} 
diminished much more considerably for the 1867 than the for the 1819 population. The context of these divergent home-leaving patterns seemed to be related to the tremendous rise in the proportion of co-resident lodgers among young adults. That rise was most probably caused by the presence of large numbers of soldiers in the city, who rented part of the premises from householders to whom they were not related. This upsurge in the number of young, mostly unmarried, people in their twenties not having yet attained headship can also explain a delayed increase in headship rates among adult males in 1867. If that were the case, then the observed pattern may only indicate a temporary alteration, and not a behavioural change related to household formation at these younger ages. In contrast to the trend seen in 1819, elderly males in 1867 tended to live in the households of relatives, rather than to co-reside with non-related heads.

Developments among women in 1819 match very closely those of women in 1867, apart from a slight increase in headship rates over time. It cannot be stated with certainty, however, whether the significant shifts observed among elderly women between 1819 and 1867 (increase in female headship rates in later stages of life; decline in co-residence as inmates in favour of living in households of relatives) can be taken at face value. Artificial effects caused by defective information in 1819 census cannot be ruled out here.

Additional exercises may shed some more light on male and female residential opportunities, and the way they changed over time (Figures 21-24) ${ }^{33}$. In this case, all individuals listed in households were classified according to whether they were or were not members of a core family group, defined as including unmarried children resident with at least one parent, married couples and lone parents. All persons who were not members of core families were classified according to whether they lived with relatives, with non-relatives only, or alone. In contrast to the previous exercises, in this case the relatives have been identified not by their relationship to the household head, but by their relationship with any household member (including inmates) in the absence of closer family ties (see Wall, 1998). The relationships within the household of each person change over the individual life course. Overall, we can distinguish thee stages for the inhabitants of Rostock during the $19^{\text {th }}$ century: during childhood (age groups 0-14 years) most young people lived with at least one of the parents; during youth and young adulthood (age groups 15-24 for women and 15-29s for men), at least half of them co-resided with people with whom they had neither closer nor any other kinship ties; and in adulthood,

\footnotetext{
${ }^{33}$ Again, because of the relatively good match of real and synthetic data for 1819 and 1867, only the former are displayed.
} 
most of them lived in conjugal units, either with or without children. However, there were people in each age group who lived in a constellation that differed from that of the majority.

The proportion of men living as a non-relatives in the second stage of life increased between the censuses, which can be attributed in part to military service. In addition to leaving home for occupational or educational reasons, many young men left to serve in the military. Also, in adult life some $10 \%$ of individual males shared domestic units with non-related persons only (either they lived as non-relatives in someone else's household, or they headed their own household with only non-related people). This share was higher for older people, and was especially high for women in 1819. The latter pattern, however, seems to be potentially affected by the procedures for establishing borders between households, since the algorithm yields lower percentages of older women than of non-relatives.

According to all the datasets, equally few males lived completely alone both in 1819 and in 1867. Also, there was no change between the listings in the share of lone fathers aged 60 and above $(10 \%)$. Living with related people other than a spouse, child or parent was generally quite uncommon both for men and women, and in both censuses. However, between 1819 and 1867 , this pattern of co-residence gained in importance somewhat, particularly among older women.

One striking feature of the developmental pattern among women was the significant increase in the share of lone mothers in age group 60 and above. This trend is confirmed by both real and synthetic data (respectively: $16.7 \%$ to $26.4 \%$, and $15.7 \%$ to $27.4 \%$ ), and seems to point to some important demographic and residential alterations taking place between the censuses. Overall, the changes during these 50 years were rather small, and affected almost exclusively the older population.

Finally, we analysed the proportion of the population living with a father, a mother or a child by age groups (Figures 25-27). This shows a pattern of leaving home in age groups 15-19 and 20-24 for both sexes. Leaving home occurred earlier for men than for women, and fewer men lived with their parents in the age group 20-24 in 1867 than in 1819. For women, we do not observe a similar change, and, later in life as well, only minor changes can be seen, mainly because the percentages were very low. However, there were changes in the youngest age groups: The share of children living with their parents increased in this time period, which could be attributed to a decrease in adult mortality, or, more likely, to fewer children being raised as foster children because of the social or living conditions of the parents or the mother.

The high age at marriage also led to childbearing later in life: Only in the age group 30-34 did half of the population have at least one child living in the same household. We can observe that the peak was reached in the age group $45-49$, when more than $70 \%$ of men and more than 
$60 \%$ of women had at least one child in the same household. These shares were higher for the second census, and indicate slightly higher chances of successful reproduction. The high proportion of childless people (about a quarter of men and a third of women) is to a large extent the effect of the high share of permanently unmarried people. After the peak, the percentage of adults living with at least one child steadily decreased, and in the oldest age group (80 and above) less than $40 \%$ of men and less than $30 \%$ of women co-resided with a child. Among this oldest age group, we can observe an increase in co-residence with a child in 1867.

\section{Patterns of leaving home}

Analysis of sex-specific patterns of leaving home in both censuses corroborates our previous observation regarding the important family change taking place between 1819 and 1867 (Figures 28-29). Non-negligible discrepancies can be observed in the exit rates of males and females between the censuses. In general, children of both sexes were staying at home longer in 1819 than in 1867. This increase in exit rates over time should be reflected in compositional changes in the city's occupational structure. Unfortunately, we do not yet have occupational titles coded, and we can therefore only speculate about the reasons for the observed change in patterns of leaving home. More "traditional" patterns detected in 1819 might have been related to proto-industrial, that is, to more domestic-based forms of household production, which were disappearing over time. An increase in the number of urban rather than rural children leaving home to work as servants or apprentices in the households of others in Rostock might also have occurred. In addition, the rise in schooling that was taking place in the city starting in the 1840s might have led to an increase in the number of children in boarding schools.

The fact that children were leaving home earlier in 1867 also means that the opportunities to form multigenerational, lineally extended households were decreasing over time. Apparently, we have more complexity in 1867 , but it must have resulted from other forms of intergenerational jointness.

\section{Residential patterns of the elderly:}

Figure 30 shows both stability and change in the residential patterns of elderly male heads in the real and in the synthetic datasets. Despite an increase in children's exit rates from home between 1819 and 1867, living with a child and a spouse (with or without others) remained the most widespread pattern of co-residence for the elderly in both censuses. Also, the proportion of coresidents with a spouse only remained at a stable level of some $15 \%$. However, the increasing speed of leaving home over time is confirmed by the fact that the proportion of male heads co- 
residing with a spouse in the absence of children is consistently higher in real and synthetic data from 1867. Nevertheless, all these figures mean that, in both censuses, the majority of male elderly heads still co-resided with at least one member of their immediate conjugal family. Both the real and the synthetic data also show a slight increase in male heads co-residing with relatives only, which was the part of a more general rise in extended family arrangements. Finally, these processes among male elderly heads were accompanied by a decline in living alone or with nonrelatives only. This observation runs contrary to the usual structural-functionalist assumptions regarding the effect of urban life on family.

Assessments of the living arrangements of older women (aged 65 or older, and either the head of a household or the wife of a household head) are very much affected by the method of delimiting households (Figure 31). Therefore, the actual living arrangements cannot be reconstructed with certainty. The only result we can present up to now is that fewer women lived with a spouse and a child, and that more women lived alone or with a child, but no spouse. This is not surprising, since most women were younger than their husbands, and thus more women became widows than men became widowers.

\section{Service system}

There was a decline in the overall proportion of servants between 1819 and 1867 (Table 3), from $16.9 \%$ of the total population to $14.2 \%$. However, the mean age of servants remained stable between the censuses, as did the patterned tendency for female servants to be older on average than male servants. In 1819, as well in 1867, the mean age of servants remained at around 22-23 for males and 25-26 for females. In order to move beyond this highly aggregated measure, we need to look more carefully at the age structure of the servant population (Figures 32-33).

Figure 32 confirms there was a decline in service over time. However, this change did not affect males and females in the same way. The share of males who worked as servants declined proportionally among all age groups, with the exception of the youngest. Among females, however, a similar change most strongly affected the prime age group of female servants (ages 20-24).

Surprisingly, there is almost no change in servants' distribution by age (Figure 33). There seems to be a contradiction in the almost unchanged age structure of servants (male and female) in 1819 and 1867, and their decrease in the share of the respective age groups of the whole city population. The age structure of the servant population remains unchanged, but there is a larger population increase in some age groups, which reduces the share of the servant population. This should be the effect of rural labour migrants coming to Rostock in search of jobs in the 
expanding industrial and service sectors. We do not have yet all the necessary data to verify this tentative observation.

This overall pattern of decline in service is also reflected at the household level (Figure 34). However, this decline has a clear life-cycle pattern: Young heads and those of middle age seemed to be affected most profoundly by the diminishing ranks of servants. The decreasing share of households with servants according to the age of the head indicates a change affecting the younger and middle generations, but not the older one. It looks like the older generation still behaved in a more "traditional" way, while an increasing number of younger household heads turned to a more "modern" type of household. This behavioural trend could have equally been the result of some unobserved changes in the production functions of household.

To learn more about the internal working of the service system, we computed the average number of offspring and servants per household by the age of the household head for both censuses (Figure 35). The comparison of information from 1819 and 1867 reveals almost no change in the average number of offspring, except in the group of older heads, among whom the number decreased between the censuses. Based on the decrease in the share of households with servants, the average number of servants appears to have declined. This finding notwithstanding, in both datasets a positive correlation is seen to exist between the number of children and the number of servants. Therefore, in both censuses, there is no replacement either of children by servants, or of servants by children, as can be observed in rural households.

\section{Conclusion}

Overall, we can observe rather stable patterns for both the 1819 and the 1867 censuses for Rostock. Age at marriage was quite high, and the proportions of the permanently unmarried were also high, especially among women. The majority of the households were nuclear family households, followed by solitaries. The average household size consisted of about four persons, and about a quarter of the population was not related to the respective household head. Most people left home as teenagers or young adults, and marriage was closely connected with obtaining headship in a household. Most elderly persons lived with a spouse and/or a child, but a considerable proportion also lived alone (especially women). Most people lived in the parental household as children, and as part of a couple in adult life. In between, about half of them had a phase of living with non-related people. A considerable share of them were servants, which showed a clear life-cycle pattern.

Changes during the 50 years between these two censuses can be observed first among the younger age groups. It is among those subsets of the city population that the emergence of a new 
sequence of life course transitions can be detected. They left home earlier, and a rising proportion lived either alone or as non-relatives in other people's households. The proportion of servants among those unrelated persons diminished during this time period. There were better marriage opportunities for middle-aged men, but worse marriage opportunities for women in the same age group. However, the connection between marriage and obtaining headship significantly weakened, leading to higher quota of never-married male household heads in 1867 . There were also increases in successful reproduction and in co-residence with children at old age. A significant rise in the share of lone mothers among the aged points in the same direction.

A slight increase in extended family households and in the proportions of households containing relatives other than the nuclear family core points to an increasing propensity to coreside with relatives. However, an overall change in the household structure pattern in the city remained very small over time. Whether our observation of change in co-residence with kin is to be seen to support Anderson's "adaptation" hypothesis is disputable. Indeed, the change occurs in the predicted direction, but the magnitude of that change seems to be too small to prove the hypothesis.

We can therefore observe only small shifts from more "traditional" towards more "modern" patterns. In general, if we assume that the socioeconomic changes that were taking place in Rostock between 1819 and 1867 were powerfully linked to structural alterations in the prevailing patterns of the family, such trivial changes in household system (both observed and synthetic) in the population under study inevitably surprise. It is possible, however, that Rostock of 1867 was still anticipating the more drastic changes that would take place in the final third of the 19 th century.

By demonstrating such a striking continuity in the overall pattern of the family in Rostock, despite the ongoing process of social change, we join the scholars who argue that family change may not be linked directly and immediately to structural social change (Kertzer 1984; Janssens 1986, 1993). We do so only partly, however, and with the impression that the implications of this study are very much different from those of Italian or Dutch cases. Considering the underlying theoretical tenets of this work, the fact that the persistence of the family pattern in Rostock rested primarily on the continuity of nuclear family-centred patterns of co-residence puts us in a truly paradoxical position. We neither detected the destruction of the traditional pattern of the extended-family household, nor proved the progressive nuclearisation of the family in Rostock between 1819 and 1867. Our rejection of structural-functionalist developmental theories points to the unambiguous fact that, in 19th-century Rostock, both "tradition" and "modernity" were marked by the prevalent nuclearisation of co-residence. 
This paradoxical situation prompts us to ask several interesting questions. While it can be true that structural differentiation within the social system does not produce the nuclear family in a causal fashion (Janssens 1986, 27), it may equally be true that social change and family change may not correspond at all. Was that lack of family change in the course of socio-structural developments in Rostock predetermined by the original nuclearisation of the family system that was occurring more broadly? If families continue to respond to turbulent social developments surrounding them by adhering to traditional family patterns (Scott and Tilly 1975), should we think of the inhabitants of this historic Hanseatic town as having been much better equipped to cope with challenges of the emerging urban-industrial life? What are the implications of the fact that the seemingly good "structural fit" between the Rostock nuclear family system and modernisation processes of the 19th-century never fostered a truly advanced industrial community?

Must we inevitably assume that further post-1867 developments in Rostock would inevitably lead to the rise in extended living arrangements? Or, maybe, it is possible to conceptualize that a later and more intense structural differentiation of the social system in the city occurred without any direct congruence with family change. But what if progressive modernisation of patterns of the family accelerated during the last three decades of the 19th century? Can we imagine that the population of Rostock may have pioneered the move towards "postnuclear family trends" (Popenhoe 1988, 295-306) as early as at the beginning of the $20^{\text {th }}$ century? Answering those questions must await further investigation.

We have done many sums and have counted a great many items, and we hope we have demonstrated the validity of the approach taken here. We must also, however, discuss briefly the limitations of our study. First and foremost, the deficiencies of 1819 census must be emphasised. Undoubtedly, some of our estimations are potentially affected by missing household borders in 1819, as well as by the limitations of the procedures for creating, either by hand, or through the algorithm. However, we have tried hard to minimise those potential errors with five versions of the alorithm, and, in fact, most of the "real" data results presented so far were consistent with synthetic files created by the computer programme.

Some might argue that the cross-sectional approach applied in this paper is not the most suitable tool for studying the evolution of household structure over time (Janssens 1993). Not very much can be done in this regard, apart from an intensification of our efforts to make microcensus data from the 1900 enumeration ready for analysis. Still, we believe that reliable census counts for one population at three different points in time, together with continuous series of vital statistics over almost the entire 19th century, open up non-negligible opportunities for 
investigating family change. If there are any significant changes in the life-cycle pattern of household extension over time, they should also be visible in the cross-section.

This preliminary study also makes no attempt to examine the influence of social class on the structure of the households and the life-course patterns of individuals. By developing a standardised system of occupational categories, this weakness will be overcome easily at later stages of research. It may then be revealed that the population aggregates used in this study actually obscured social class-specific patterns of family change taking place in Rostock (Szreter 1996, 546-558).

\section{REFERENCES}

Anderson, M. (1971). Family Structure in Nineteenth-Century Lancashire (Cambridge).

Andorka, R. and S. Balazs-Kovacs (1986). The Social Demography of Hungarian Villages in the Eighteenth and Nineteenth Centuries (with Special Attention to Sarpilis, 1792-1804). Journal of Family History, vol. 11. no. 2. 169-192.

Arcury, T. (1990). "Industrialization and Household Family Life Characteristics: Appalachian Kentucky Young Adults in 1880 and 1910," Journal of Family History 15; 285-312.

Berkner, L. K., (1975). The use and misuse of census data for the historical analysis of family structure. Journal of Interdisciplinary History, 5 (4), 721-738.

Berkner L. K. (1972). Rural family organization in Europe: a problem in comparative history, „Peasant Studies Newslatter" 1, 145-156.

Berquo, E. and P. Xenos, (Eds.), 1992. Peter Family Systems and Cultural Change (Oxford: Clarendon Press).

Billari F.C., Philipov, D. \& P.B. Munoz (2001). "Leaving home in Europe: the experience of cohorts born around 1960," MPIDR Working Papers, WP-2001-014, Max Planck Institute for Demographic Research, Rostock, Germany.

Boch, R. (2004), Staat und Wirtschaft im 19. Jahrhundert. = Enzyklopädie Deutscher Geschichte, Vol. 70. München: Oldenburg

Bras, Hilde and Jan Kok: '"Naturally, Every Child Was Supposed to Work". Determinants of the Leaving Home Process in The Netherlands, 1850-1940', pp 403-450 in: F. VAN POPPEL, M. ORIS and J. LEE (eds), The Road to Independence. Leaving Home in Western and Eastern Societies, 16th- $20^{\text {th }}$ centuries (Bern: Peter Lang, 2004).

Burch, T.K. (1995). "Theories of household formation: progress and challenges." In E. van Imhoff, A.C. Kuijsten, P. Hooimeijer, and L.J.C. van Wissen [eds.] Household Demography and Household Modeling. New York: Plenum Press, 1995. pp. 85-108.

Burch, T.K. (1980). The index of overall headship: a simple measure of household complexity. Demography, 17(1): 25-37.

Cain, M. (1991). 'Welfare Institutions in Comparative Perspective: The Fate of the Elderly in Contemporary South Asia and Pre-Industrial Western Europe', pp. 222- 243 in Life, death, and the elderly: historical perspectives, eds. Margaret Pelling \& Richard Michael Smith. London: Routledge.

Collomp, A. 1988. "Changes in the Coresident Group in Haut Provence Between the End of the Eighteenth and the Middle of the Nineteenth Centuries ." Continuity and Change 3: 65-81.

Cooper, S. M. (2005). 'Service to servitude? The decline and demise of life-cycle service in England'. History of the Family, 10:4, 367-86.

Das Gupta, M. (1999). Lifeboat versus corporate ethic: social and demographic implications of stem and joint families. Social Science and Medicine, 49(2), 173-84.

Das Gupta, M. (1997). Kinship systems and demographic regimes. In: Anthropological demography: 
toward a new synthesis, edited by David I. Kertzer and Tom Fricke. Chicago, Illinois, University of Chicago Press, 1997. :36-52.

De Vos, Susan and Yean-Ju Lee. 1993. "Change in extended family living among elderly people in South Korea, 1970-1980," Economic Development and Cultural Change 41: 377-393.

Dillon, Lisa (2008). The Shady Side of Fiffy: Age and Old Age in Late Victorian Canada and the United States. Montreal and Kingston: McGill-Queen's University Press.

Dribe, M. (2000), Leaving home in a peasant society. Economic fluctuations, household dynamics and youth migration in southern Sweden, 1829-1866, Lund Studies in Economic History 13, Lundh.

Duben, A. and C. Behar (1991). Istanbul households : marriage, family, and fertility, 1880-1940. Cambridge: Cambridge University Press.

Egerbladh, I. (1989). From Complex to Simple Family Households: Peasant Households in Northern Coastal Sweden 1700-1900, Journal of Family History, Vol. 14, No. 3, 241-64.

Ermisch, J. (1988), "An economic perspective on household modelling," in Modelling housebold formation and dissolution, edited by Nico Keilman, Anton Kuijsten and Ad Vossen. Oxford, England, Clarendon Press, 1988: 23-40.

Fauve-Chamoux, A. (2004) (Ed.), Domestic service and the formation of European identity. Understanding the globalization of domestic work, $16^{\text {th }}-21^{\text {st }}$ centuries, Bern: Peter Lang.

Fauve-Chamoux, A. (1983). "The importance of women in an urban environment: the example of the Rheims household at the beginning of the industrial Revolution", In Family Forms in Historic Europe, R. Wall, J. Robin and P. Laslett (eds), Cambridge, Cambridge University Press, pp. 475492.

Fitzpatrick, D. (1983). Irish Farming Families before the First World War, Comparative Studies in Society and History, Vol. 25, No. 2, pp. 339-374.

Freedman, Ronald, Ming-cheng Chang, and Te-hsuing Sun. 1982 . Household Composition, Extended Kinship, and Reproduction in Taiwan: 1973-1980; Population Studies 36(3): 395-411.

Gates, H. and F. Hendrickx, Servants and service in Eurasia, pp. 289-327 in Engelen T., and A. Wolf (Eds.), Marriage and the Family in Eurasia: Perspectives on the Hajnal Hypothesis. Amsterdam.

Goode, W.J. (1963). World revolution and family patterns. Glencoe, IL: Free Press.

Goode, W. J. (1966). "Industrialization and Family Change." In Industrialization and Society, edited by Bert F. Hoselitz and Wilbert E. Moore, New York: UNESCO, 237-55.

Gore, M. S. (1968). Urbanization and family change.Popular Prakashan (Bombay).

Haack, H. (1977). Bevölkerungswachstum in Mecklenburg-Schwerin 1819 bis 1905, In: Wissenschaftliche Zeitschrift der Wilhelm-Pieck-Universität Rostock, Gesellschafts- und Sprachwissenschaftliche Reihe, Vol. 26, 1977, Issue 10, pp. 931-936.

Halpern, J. (1972). "Town and countryside in Serbia in the nineteenth-century, social and household structure as reflected in the census of 1863", In P. Laslett \& R. Wall (Eds.), Household and family in past time (pp. 401-427). Cambridge: Cambridge University Press.

Hammel, E.A. (1984), "On the *** of studying household form and function," In: Households: comparative and historical studies of the domestic group, edited by Robert McC. Netting, Richard R. Wilk, and Eric J. Arnould. Berkeley, California, University of California Press, 1984 :29-43.

Hammel, E. A. and Kenneth W. Wachter (1996a). "Evaluating the Slavonian Census of 1698: Part I: Structure and Meaning", European Journal of Population 12: 145-166.

Hammel, E. A. and Kenneth W. Wachter (1996b). "Evaluating the Slavonian Census of 1698: Part II: A Microsimulation Test and Extension of the Evidence", European Journal of Population 12: 295326.

Hareven T.K. (1978), "The Dynamics of Kin," in Turning Points, ed. John Demos and Sarane Boocock (Chicago), 151-181.

Hareven. Tamara K. (1982). Family Time and Industrial Time (New York: Cambridge University Press).

Hartman, M. S. (2004). The household and the making of history. A subversive view of the western past. Cambridge: Cambridge University Press.

Heitz, G. (1997), Wirtschafts- und sozialgeschichtliche Grundlage mecklenburgischer Landstädte im 19. Jahrhundert. In: Mecklenburgische Jahrbücher 112, 1997, pp. 123-150

Hubbard, William H. (1976), "Forschungen zur städtischen Haushaltsstruktur am Ende des 19. Jhs. Das GRAZHAUS-Projekt," in Werner Conze, ed., Sozialgeschichte derFamilie in der Neuzeit Europas. Neue Forschungen (Stuttgart: Klett, 1976), pp. ??

Hubbard, William H. (1984). Auf dem Weg zur Großstadt. Eine Sozialgeschicbte der Stadt Graz 1850 - 1914 
(Sorial- und wirtschaftshistorische Studien, vol. 17), Wien, München.

Karge, W., Schmied, H. \& Münch, E. (2004[1993]). Die Geschichte Mecklenburgs. Rostock: Hirnstorff Janssens, A. (1986). Industrialization without Family Change? The Extended Family and the Life Cycle in a Dutch Industrial Town, 1880-1920. Journal of Family History, Vol. 11, No. 1, 25-42.

Janssens, A. (1993). Family and Social Change. The Household as a Process in an Industrializing Community. Cambridge: Cambridge University Press.

Katz, Michael B. (1975). The People of Hamilton, Canada West: Family and Class in a Mid-19th Century City. Harvard University Press.

Kertzer, David I., 1984 Family life in central Italy, 1880-1910 : sharecropping, wage labor, and coresidence.Rutgers University Press.

Kertzer, David I. and Andrea Schiaffino 1983 "Industrialization and Coresidence: A Life Course Approach." In Paul B. Baltes and Orville G. Brim, Jr., eds., Life-Span Development and Human Behavior, vol. 5, 360-391. New York: Academic Press.

Kertzer David I. and Peter Laslett, eds. (1995). Aging in the Past: Demography, Society, and Old Age, Berkeley and Los Angeles: University of California Press.

King, Steven, 1966-. 'English historical demography and the nuptiality conundrum : new perspectives'. Historical Social Research, 23 (1998), 130-56

Kok, J. (2007). 'Principles and prospects of the life course paradigm', Annales de Démographie Historique, nr $1,203-230$.

Krüger, K. \& Straßburg, J. (2002). Armenfürsorge in Rostock 1804-1822. In: Deventer, J. (Ed) Zeitenwenden, Herrschaft, Selbstbehauptung und Integration zwischen Reformation und Liberalismus. Festgabe für Arno Herzig zum 65. Geburtstag, pp. 507-524. Münster / Berlin: Lit Verlag

Kuna, E. \& Deya, H. (2007), Neues historisches Lexikon. E-Book. Haff Verlag.

Kussmaul, A. (1981). Servants in husbandry in early-modern England. Cambridge7 Cambridge University Press.

Laslett, P. (1988). Family, kinship and collectivity as systems of support in preindustrial Europe: a consideration of the »nuclear-hardship« hypothesis. Continuity and Change, 3(2), 152-175.

Laslett, P. (1983). Family and household as work group and kin group: areas of traditional Europe compared. In R. Wall \& J. Robin (Eds.), Family forms in historic Europe (pp. 513-563). Cambridge: Cambridge University Press).

Laslett, P. (1977). "Charcteristics of the Western family considered over time", 12-49, in P. Laslett, Family life and illicit love in earlier generations. Essays in historical sociology, Cambridge, Cambridge University Press.

Laslett, P. (1972a). Introduction. In P. Laslett \& R. Wall (Eds.), Household and family in past time (pp. 1-89). Cambridge: Cambridge University Press.

Laslett, P. (1972b). 'Mean household size in England since the sixteenth century', In P. Laslett \& R. Wall (Eds.), Household and family in past time (pp. 125-158). Cambridge: Cambridge University Press.

Laslett, P., Wachter, K.W., \& Laslett, R. (1978). The English evidence on household structure compared with the outcomes of microsimulation. In K. W. Wachter, E. A. Hammel \& P. Laslett, Statistical studies of historical social structure (pp. 65-87). New York: Academic Press.

Lee, Gary R. (1982). Family structure and interaction. a comparative analysis, University of Minnesota Press (Minneapolis).

Lee, J. \& Gjerde, J. (1986). Comparative morphology of stem, joint, and nuclear household systems: Norway, China and the United States. Continuity and Change, 1, 89-111.

Litchfield, R. B. (1988). "Single People in the 19th Century City: a comparative perspective on occupations and living situations, Continuity and Change 3(1) pp. 83-100.

Macfarlane, A. 1978. The origins of English individualism: the family, property and social transition. Oxford: Blackwell.

Macfarlane, A. 1987. Marriage and Love in England: Modes of Reproduction 1300-1840. Blackwell.

Martin, Linda G. 1990. "Changing intergenerational family relations in East Asia," Annals of the American Academy of Political and Social Science 510: 102-114.

Matthias Manke, Möglichkeiten und Grenzen der soziostrukturellen Auswertung der Volkszählungslisten 1819 für Rostock. In: Ilona Buchsteiner, ed., Mecklenburg und seine ostelbischen Nachbarn: historisch-geographische und soziale Strukturen im regionalen Vergleich. Schwerin 1997, pp. $122-$ 133. 
Matthias Manke, Die historische Bevölkerungsstatistik in Mecklenburg-Schwerin bis zur ersten Hälfte des 19. Jahrhunderts. In: Genealogie, Vol. 24, No. 9-10, 1999, pp. 641-658.

Manke, M. (2000). Rostock zwischen Revolution und Biedermeier. Alltag und Sozialstruktur. Rostock: Neuer Hochschulschriftenverlag.

Manke, M. (Ed., 2005). „...dass alle Welt geschätzt würde.“ Die Einwohner der Stadt Rostock nach der Volkszählung von 1819. Rostock: Ingo Koch Verlag.

Manke, M. (2005). Die Volkszählungen des Großherzogtums Mecklenburg-Schwerin in den Jahren 1819 und 1867 unter Mitberücksichtigung der Volkszählung des Jahres 1866. In: Genealogie. Deutsche Zeitschrift für Familienkunde, Vol 27, Issue 3-4, March / April 2005, pp. 449-468. Insingen: Degener Verlag.

Mayer, K. U. (2001). The paradox of global social change and national path dependencies: Life course patterns in advanced societies. In A. E. Woodward \& M. Kohli (Eds.), Inclusions and exclusions in European societies (pp. 89-110). London: Routledge.

McDonald, P. (1992). "Convergence or Compromise in Historical Family Change?", PP. 15-30 in Family Systems and Cultural Change, ed. Elza Berquo and Peter Xenos (Oxford: Clarendon Press).

Mecklenburgischer Staatskalender, 1795-1914, Schwerin: Verlag der Hofbuchdruckerei

Medick, H. (1981) The protoindustrial family economy," pp. 38-73 in Industrialization Before Industrialization, ed. P Kriedte, H Medick, J Schlumbohm.

Mendels, Franklin F. 1972 "Proto-industrialization: The First Phase of the Industrialization Process." Journal of Economic History 32:241-261.

Mitterauer M. (1976). Auswirkungen von Urbanisierung und Frühindustrialisierung auf die Familienverfassung an Beispielen des österreichischen Raums, in Werner Conze, ed., Sozialgeschichte derFamilie in der Neuzeit Europas. Neue Forschungen (Stuttgart: Klett, 1976), pp. 53-146.

Moring, B. (1993). Household and Family in Finnish Coastal Societies 1635-1895. Journal of Family History 18 4, pp. 395-414.

Münch, E. (1993). Dörfer um Rostock im 18. Jahrhundert. Agrargeschichtliche Streiflichter. In: Mecklenburgische Jahrbücher 109, 1993, pp. 123-129

Münch, E. \& Schattowsky, R. (Eds., 2000), Studien zur Ostelbischen Gesellschaftsgeschichte. Festschrift für Gerhard Heitz zum 75. Geburtstag. Rostock: Ingo Koch Verlag

Neil Price and Neil Thomas (1999), Continuity and Change in the Gwembe Tonga Family and Their Relevance to Demography's Nucleation Thesis, Africa: Journal of the International African Institute, Vol. 69, No. 4 (1999), pp. 510-534.

North, M. (2008). Geschichte Mecklenburg-Vorpommerns. München: Beck.

Nosevich, V. (2004). Tradicionnaia belorusskaya dierevnia v evropeyskoy perspektivie. Minsk: Technalogya.

Oris, M., and E. Ochiai (2002). "Family Crisis in the Context of Different Family Systems." In When Dad Died: Individuals and Families Coping with Distress in Past Societies, ed. Renzo Derosas and Michel Oris. New York: Peter Lang, 17-79.

Parsons, T., \& Bales, R.F. (1955). The Family : socialization and interaction process. Free Press (Glencoe, Ill).

Polla, M. (2006). Family systems in central Russia in the 1830s and 1890s. History of the Family, 11, 27-44.

Pooley C.G. and J. Turnbull (1997). Leaving Home: the Experience of Migration From the Parental Home in Britain Since c. 1770, Journal of Family History, Vol. 22, No. 4, 390-424.

Popenoe, D. (1988). Disturbing the Nest: Family Change and Decline in Modern Societies (New York: Aldine de Gruyter).

Reher D.S. (1998). Family ties in Western Europe: persistent contrasts, Population and Development Review, vol. 24(2), p. 203-234.

Rosenbaum, H. (1996). Formen der Familie. Untersuchungen zum Zusammenhang von Familienverhältnissen, Sozialstruktur und sozialem Wandel in der deutschen Gesellschaft des 19. Jahrbunderts. Suhrkamp Taschenbuch Wissenschaft 374. 7. edition 1996

Rothenbacher, F. (1997). Historische Haushalts- und Familienstatistik von Deutschland 1815-1990. Frankfurt [u.a.] : Campus Verlag, 1997.

Ruggles S. (2009). "Reconsidering the Northwest European Family System." Population and Development Review 35: 249-273.

Ruggles S. (2009). "Multigenerational families in nineteenth-century America ." Continuity and Change 18:1, 139-165.

Ruggles S. (1987). Prolonged Connections: The Rise of the Extended Family in Nineteenth-Century 
England and America. Madison: University of Wisconsin Press.

Schellekens, J. (1997). "Nuptiality during the First Industrial Revolution in England: Explanations,". Journal of Interdisciplinary. History,. XXVII. (1997),

Schmid J. (1988). Principles emerging from sociology for definitions and typologies of household structures. In Modelling household formation and dissolution, edited by Nico Keilman, Anton Kuijsten and Ad Vossen. Oxford, England, Clarendon Press, 1988:13-22.

Schröder, K. (Ed., 2003). „In deinen Mauern herrsche Eintracht und allgemeines Wohlergehen. Eine Geschichte der Stadt Rostock von ihren Ursprüngen bis zum Jahre 1990. Rostock: Ingo Koch Verlag.

Scott J. and L.A. Tilly, (1975) "Women's Work and the Family in Nineteenth Century. Europe," Comparative Studies in Society and History, 17, 36-64.

Seccombe, W. (1990). The western European marriage pattern in historical perspective, Journal of Historical Sociology 3 (1990), 50-74.

Sennett R. (1970). Families Against the City: Middle Class Homes of Industrial Chicago, 1872-1890. Mass.: Harvard University Press.

Skinner, G. W. 1997. Family systems and demographic processes, in D. I. Kertzer and T. Fricke (eds.) Anthropological Demography. Toward a New Synthesis

Smelser, N. J., \& Halpern, S. (1978). "The Historical Triangulation of Family, Economy, and Education." American Journal of Sociology 84(Suppl.): S288-S315.

Smith, R.M. (1981). Fertility, economy, and household formation in England over three centuries. Population and Development Review, 1981 Dec;7(4):595-622, 728-30.

Sovič, S. (2008). Definitions and Documents in Family History: Towards an Agenda for Comparative Research', in Social Behaviour and Family Strategies in the Balkans (16 th -20 th Centuries). Proceedings of a Regional Symposium, New Europe College Bucharest, June 9-10, 2006. Bucharest, 137-158.

Spoorenberg, T. (2007). Quality of age reporting: Extension and application of the modified Whipple's index. Population-E 62 (4): 729-742.

Stutz, R. (1998). Zur kapitalistischen Umgestaltung der Landwirtschaft im Großherzogtum MecklenburgSchwerin in der 2. Hälfte des 19. Jahrhunderts. In: Mecklenburgische Jahrbücher, Vol.113, 1998, pp. 255

Szołtysek, Mikołaj. 2008a. "Three kinds of preindustrial household formation system in historical Eastern Europe: A challenge to spatial patterns of the European family". The History of the Family 13 (3): 223-257.

Szołtysek, Mikołaj. 2008b. 'Eastern European predicament: three household formation rules and two family welfare systems in the eighteenth-century Polish-Lithuanian Commonwealth?' Paper presented at The Jubilee Conference: " 25 years of Family forms and beyond: revising geographies, methodologies, explanations", University of Cambridge, 20-21.05. 2008.

Szreter, S. (1996). Fertility, Class and Gender in Britain, 1860-1940, Cambridge: Cambridge University Press.

Todd E. (1985), Explanation of Ideology: Family Structures and Social Systems (Family, sexuality, and social relations in past times). Blackwell

Tscharnke, Johannes (1943). Anlässe und Gebiete der Volkszählungen in beiden Mecklenburg. Jur. Diss. Rostock.

Van Poppel, F., Oris, M. (2004), "Introduction", 1-29, in The Road to Independence : Leaving Home in Western and Eastern Societies, 16th-20th Centuries, edited by F. W. A. van Poppel, M. Oris, and J.Z. Lee, New York: Peter Lang.

Wall, R. (2001a). Transformation of the European family across the centuries. In R. Wall, T. K. Hareven, J. Ehmer \& M. Cerman (Eds.), Family bistory revisited. Comparative perspectives (pp. 217-241). Newark: University of Delaware Press).

Wall, R. (2001b). The Household. In: Peter N. Stearns, ed., Encyclopedia of European Social History, Vol. 4. Detroit, pp. 109-124.

Wall, R. (1998). Characteristics of European family and household systems, „Historical Social Research” 23 (1-2), pp. 44-66.

Wall, R. (1995) »Historical development of the household in Europe.« In: Imhoff, Evert van et al. (eds.) Household demography and household modelling, eds. E.v.Imhoff, A.Kuijsten, P.Hooimeijer, and L.v.Wissen, pp. 19-52 (New York and London, Plenum Press).

Wall, R. (1991). European family and household systems. In Historiens et populations. Liber Amicorum Etienne 
Helin (pp. 617-636). Louvain-la-Neuve: Academia.

Wall, Richard (1978) "The age at leaving home." Journal of Family History 3:181-202.

Wall, R., (1977). Regional and temporal variations in English household structure from 1650. In J.Hobcraft \& P. Rees (eds.), Regional demographic development (pp. 89-113). London: Croom Helm.

Werz, N. \& Nuthmann, R. (Eds., 2004), Abwanderung und Migration in Mecklenburg und Vorpommern. Wiesbaden: Verlag für Sozialwissenschaften.

Wilk, Richard R. and Netting, Robert McC. 1984. "Household: Changing Forms and. Functions." In Wilk, Netting and Arnould, eds., Households ??

Wong, F.-M. (1975). Industrialization and Family Structure in Hong Kong, Journal of Marriage and Family, Vol. 37, No. 4, Special Section: Macrosociology of the Family (Nov., 1975), pp. 985-1000.

Wrigley E. Anthony (1977). Reflections on the History of the Family, Daedalus, Vol. 106, No. 2, (Spring, 1977), pp. 71-85.

E. A. Wrigley, R. S. Schofield, The Population History of England 1541-1871: a Reconstruction, London 1981.

Yanagisako, S. J. (1979) "Family and household: the analysis of domestic groups."Annual Rev. of Anthropology" 8: 161-205. 


\section{APPENDIX: TABLES and FIGURES}

Table 1: Household typology according to Hammel-Laslett scheme

\begin{tabular}{|c|c|c|c|c|c|c|c|c|c|c|c|c|c|}
\hline & \multicolumn{6}{|c|}{1819} & \multicolumn{6}{|c|}{1867} \\
\hline & & \multicolumn{3}{|c|}{ real } & \multicolumn{3}{|c|}{ synthetic } & \multicolumn{3}{|c|}{ real } & \multicolumn{3}{|c|}{ synthetic } \\
\hline & & abs. & $\%$ & Cat. \% & abs. & $\%$ & Cat. \% & abs. & $\%$ & Cat. \% & abs. & $\%$ & Cat. \% \\
\hline \multirow{2}{*}{$\begin{array}{l}. \\
\text { Solitaries }\end{array}$} & $1 a$ & 233 & 6.48 & \multirow{2}{*}{17.41} & 513 & 13.09 & \multirow{2}{*}{25.60} & 476 & 7.03 & \multirow{2}{*}{17.84} & 501 & 7.48 & \multirow{2}{*}{19.89} \\
\hline & $1 b$ & 393 & 10.93 & & 490 & 12.51 & & 732 & 10.81 & & 832 & 12.42 & \\
\hline \multirow{3}{*}{$\begin{array}{l}\text { 2. No } \\
\text { family }\end{array}$} & $2 a$ & 35 & 0.97 & \multirow{3}{*}{2.00} & 41 & 1.05 & \multirow{3}{*}{2.37} & 101 & 1.49 & \multirow{3}{*}{2.75} & 109 & 1.63 & \multirow{3}{*}{2.75} \\
\hline & $2 b$ & 37 & 1.03 & & 52 & 1.33 & & 85 & 1.26 & & 75 & 1.12 & \\
\hline & $2 c$ & 0 & 0.00 & & 0 & 0.00 & & 0 & 0.00 & & 0 & 0.00 & \\
\hline \multirow{4}{*}{$\begin{array}{l}\text { 3. Simple } \\
\text { family } \\
\text { households }\end{array}$} & $3 a$ & 612 & 17.02 & \multirow{4}{*}{75.38} & 615 & 15.70 & \multirow{4}{*}{67.82} & 902 & 13.32 & \multirow{4}{*}{71.06} & 881 & 13.15 & \multirow{4}{*}{68.54} \\
\hline & $3 b$ & 1627 & 45.26 & & 1586 & 40.48 & & 3146 & 46.47 & & 2996 & 44.71 & \\
\hline & $3 c$ & 106 & 2.95 & & 113 & 2.88 & & 111 & 1.64 & & 109 & 1.63 & \\
\hline & $3 d$ & 365 & 10.15 & & 343 & 8.75 & & 652 & 9.63 & & 607 & 9.06 & \\
\hline \multirow{4}{*}{$\begin{array}{l}4 . \\
\text { Extended } \\
\text { family } \\
\text { households }\end{array}$} & $4 a$ & 71 & 1.97 & \multirow{4}{*}{5.06} & 52 & 1.33 & \multirow{4}{*}{4.19} & 175 & 2.58 & \multirow{4}{*}{8.29} & 152 & 2.27 & \multirow{4}{*}{8.66} \\
\hline & $4 b$ & 14 & 0.39 & & 10 & 0.26 & & 50 & 0.74 & & 54 & 0.81 & \\
\hline & $4 c$ & 57 & 1.59 & & 44 & 1.12 & & 183 & 2.70 & & 170 & 2.54 & \\
\hline & $4 d$ & 40 & 1.11 & & 58 & 1.48 & & 153 & 2.26 & & 204 & 3.04 & \\
\hline \multirow{5}{*}{$\begin{array}{l}\text { 5. Multiple } \\
\text { family } \\
\text { households }\end{array}$} & $5 a$ & 0 & 0.00 & \multirow{5}{*}{0.14} & 0 & 0.00 & \multirow{5}{*}{0.03} & 2 & 0.03 & \multirow{5}{*}{0.06} & 2 & 0.03 & \multirow{5}{*}{0.04} \\
\hline & $5 b$ & 3 & 0.08 & & 1 & 0.03 & & 2 & 0.03 & & 1 & 0.01 & \\
\hline & $5 c$ & 0 & 0.00 & & 0 & 0.00 & & 0 & 0.00 & & 0 & 0.00 & \\
\hline & $5 d$ & 0 & 0.00 & & 0 & 0.00 & & 0 & 0.00 & & 0 & 0.00 & \\
\hline & $5 e$ & 2 & 0.06 & & 0 & 0.00 & & 0 & 0.00 & & 0 & 0.00 & \\
\hline Total & & 3595 & 100.00 & 100.00 & 3918 & 100.00 & 100.00 & 6770 & 100.00 & 100.00 & 6693 & 100.00 & 100.00 \\
\hline
\end{tabular}

Note: Households of type 6 are excluded.

Table 2: Household summary characteristics

\begin{tabular}{|c|c|c|c|c|c|c|c|}
\hline \multirow{2}{*}{$\overline{\text { YEAR }}$} & \multicolumn{2}{|c|}{ Total households } & \multicolumn{2}{|c|}{ Total population } & \multirow{2}{*}{$\begin{array}{l}\text { Mean no of } \\
\text { offspring } \\
\text { per } \\
\text { household }\end{array}$} & \multirow[b]{2}{*}{$\begin{array}{l}\% \text { relatives } \\
\text { in the } \\
\text { population }\end{array}$} & \multirow[b]{2}{*}{$\begin{array}{l}\text { Mean no of } \\
\text { relatives per } \\
\text { household }\end{array}$} \\
\hline & $\begin{array}{l}\text { Incl. type } \\
6\end{array}$ & $\begin{array}{l}\text { Excl. type } \\
6\end{array}$ & Incl. type 6 & $\begin{array}{l}\text { Excl. type } \\
6\end{array}$ & & & \\
\hline 1819 & 3601 & 3595 & 15460 & 15390 & 1.50 & 2.15 & 0.09 \\
\hline 1867 & 6826 & 6770 & 29094 & 28511 & 1.49 & 3.40 & 0.14 \\
\hline
\end{tabular}


Table 3: Summary characteristic of household composition

\begin{tabular}{|c|c|c|c|c|}
\hline \multicolumn{3}{|c|}{ CENSUS YEAR } & 1819 & 1867 \\
\hline \multicolumn{2}{|c|}{$\begin{array}{l}\text { Total population excluding } \\
\text { hhs type } 6\end{array}$} & & 15390 & 28511 \\
\hline \multirow{2}{*}{\multicolumn{2}{|c|}{$\%$ servants in tot pop }} & freq. & 2600 & 4042 \\
\hline & & $\%$ & 16.89 & 14.18 \\
\hline \multirow{8}{*}{$\begin{array}{l}\% \text { relatives } \\
\text { in tot pop }\end{array}$} & \multirow{2}{*}{ Parents } & freq. & 67 & 219 \\
\hline & & $\%$ & 0.44 & 0.77 \\
\hline & \multirow{2}{*}{$\begin{array}{l}\text { Siblings and other } \\
\text { lateral kin }\end{array}$} & freq. & 124 & 429 \\
\hline & & $\%$ & 0.81 & 1.5 \\
\hline & \multirow{2}{*}{ Other kin } & freq. & 90 & 200 \\
\hline & & $\%$ & 0.58 & 0.7 \\
\hline & \multirow{2}{*}{$\begin{array}{l}\text { Total relatives in the } \\
\text { population }\end{array}$} & freq. & 331 & 968 \\
\hline & & $\%$ & 2.15 & 3.4 \\
\hline \multirow{6}{*}{$\begin{array}{l}\% \text { non-kin } \\
\text { in tot pop }\end{array}$} & \multirow{2}{*}{ Lodgers } & freq. & 571 & 1027 \\
\hline & & $\%$ & 3.71 & 3.6 \\
\hline & \multirow{2}{*}{$\begin{array}{l}\text { Other non-kin } \\
\text { (non-servants) }\end{array}$} & freq. & 526 & 1107 \\
\hline & & $\%$ & 3.43 & 3.88 \\
\hline & \multirow{2}{*}{$\begin{array}{l}\text { Total non-kin in the } \\
\text { population }\end{array}$} & freq. & 1097 & 2134 \\
\hline & & $\%$ & 7.14 & 7.48 \\
\hline
\end{tabular}


Figure 1: Percentage of unmarried people by age groups

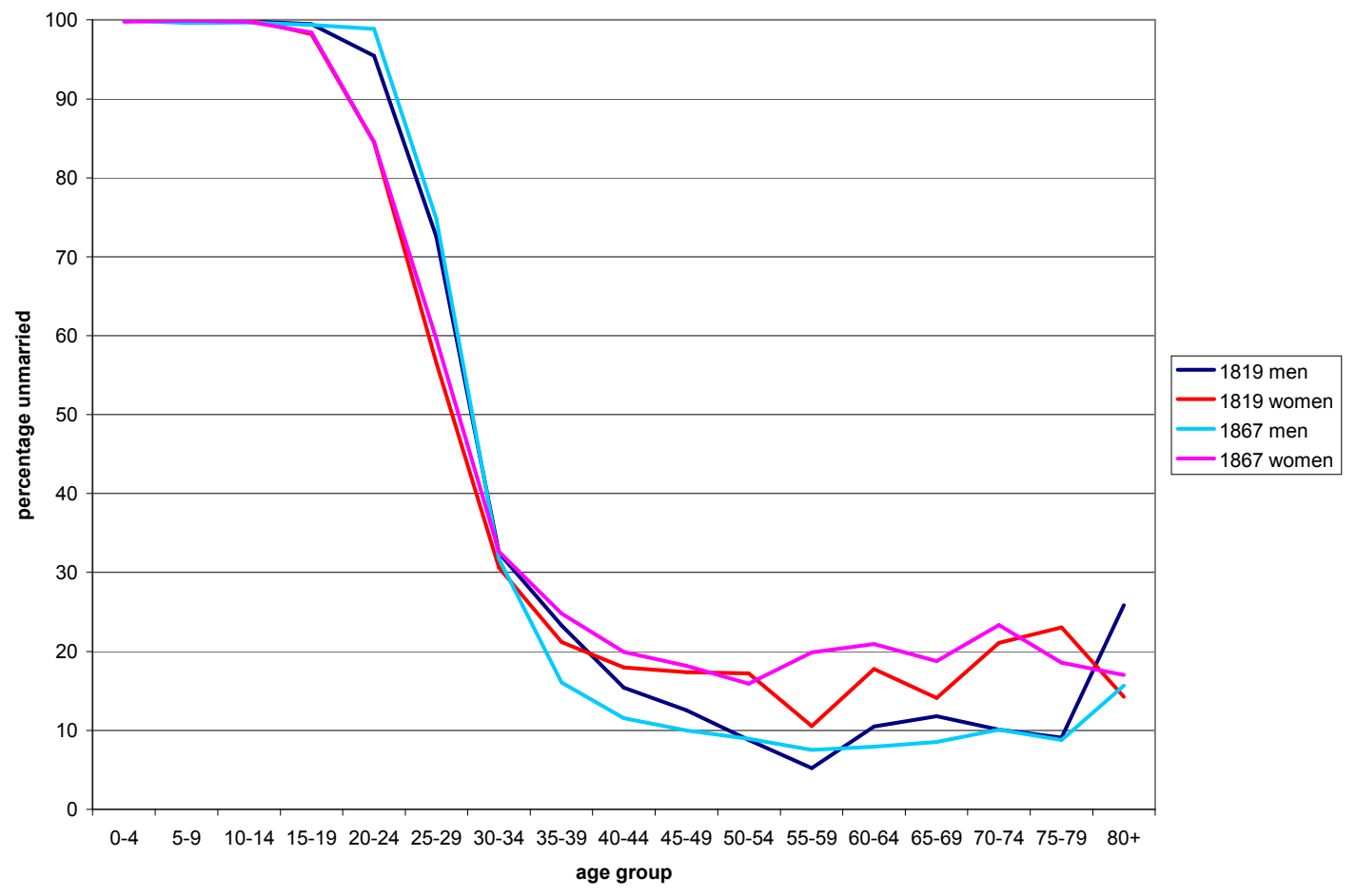

Note: Households of type 6 are excluded.

Figure 2: Household typology by age of male household head, 1819

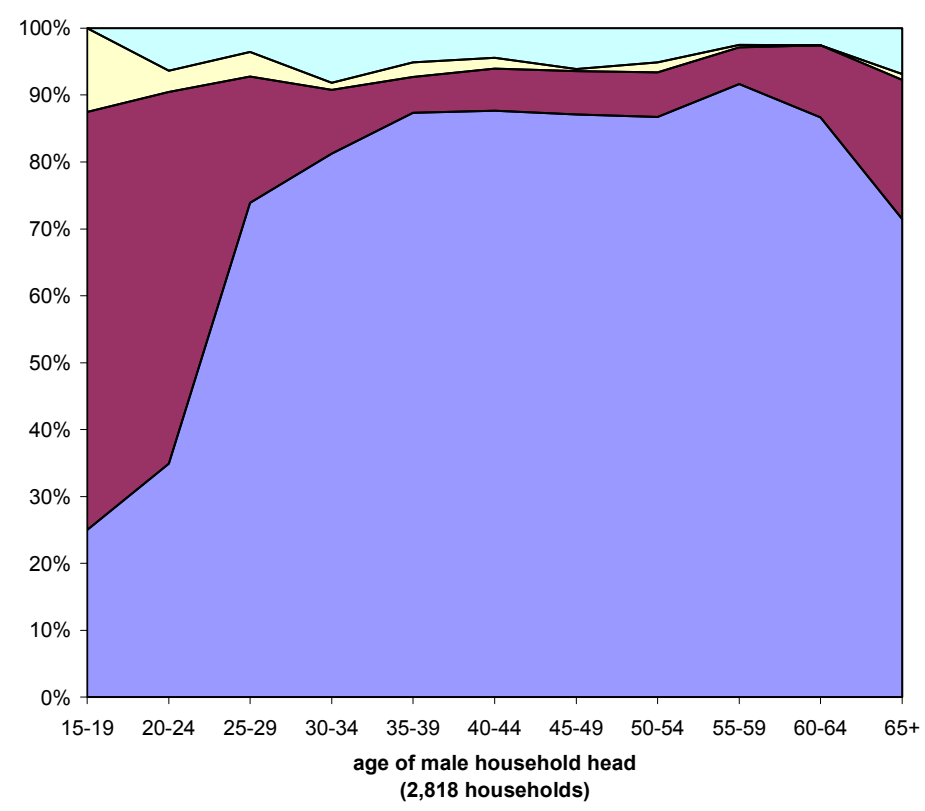

口Extended and multiple family households

$\square$ No family

口Solitaries

口Simple family households

Note: Households of type 6 are excluded. 
Figure 3: Household typology by age of male household head, 1867

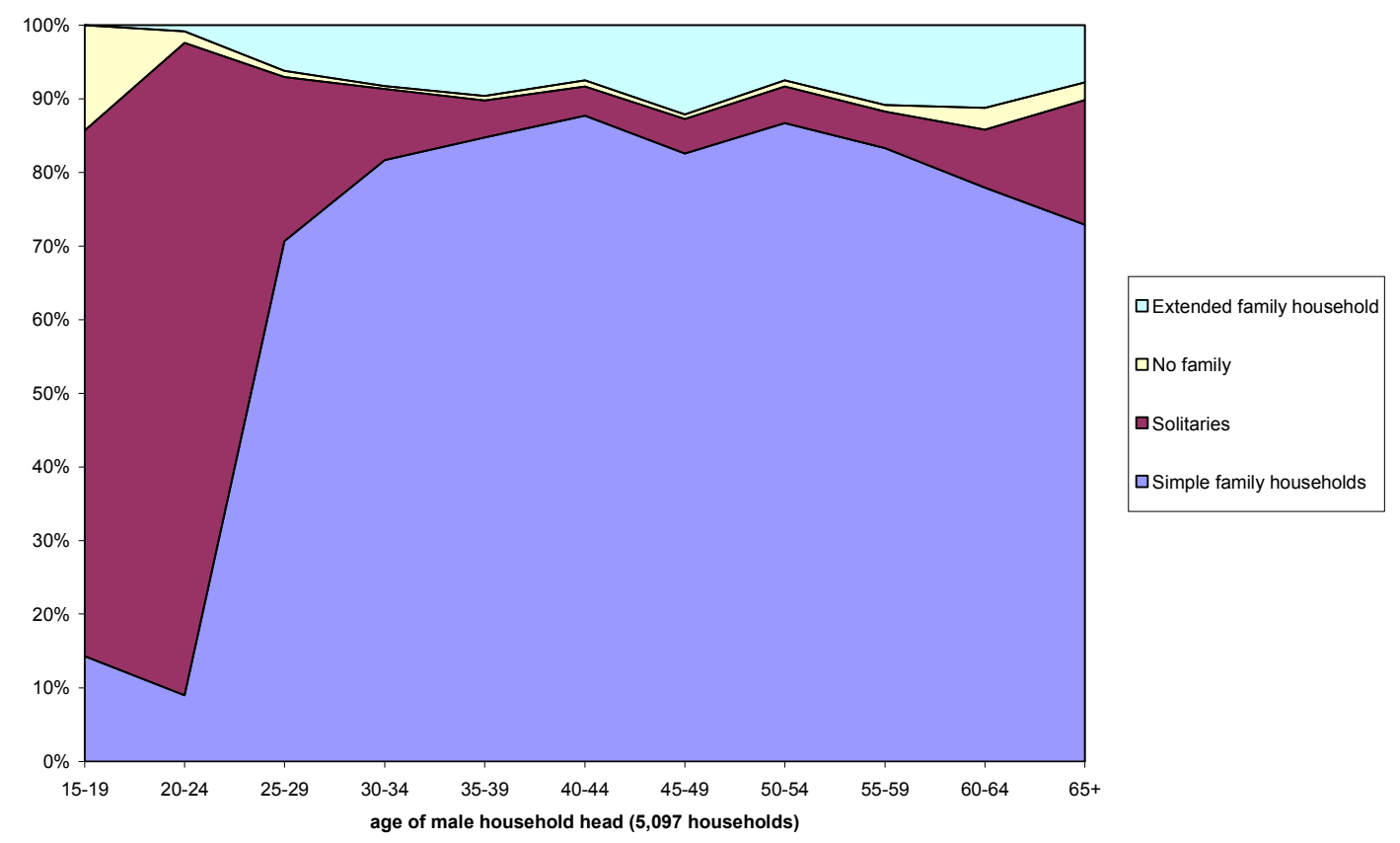

Note: Households of type 6 are excluded.

Figure 4: Household typology by age of male household head, 1819 synthetic

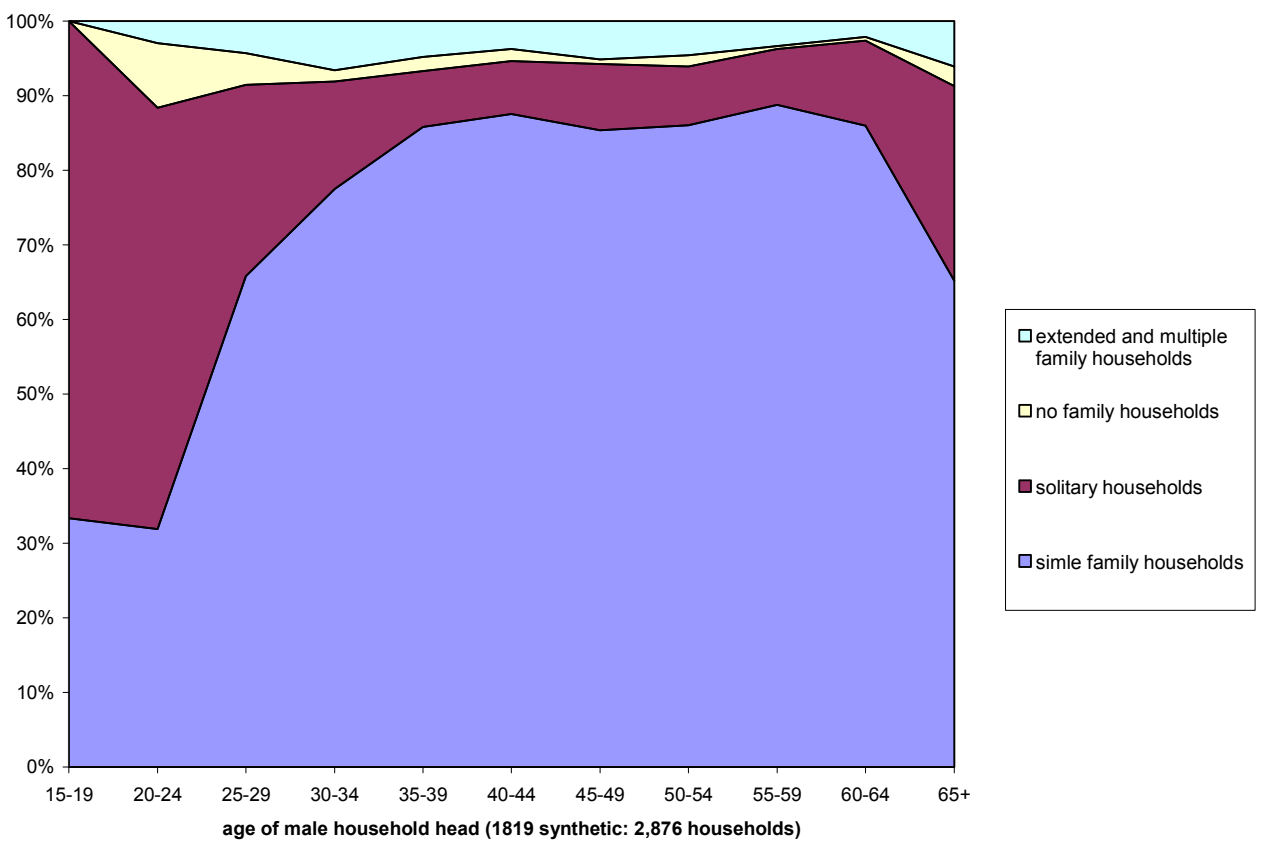

Note: Households of type 6 are excluded. 
Figure 5: Household typology by age of male household head, 1867 synthetic

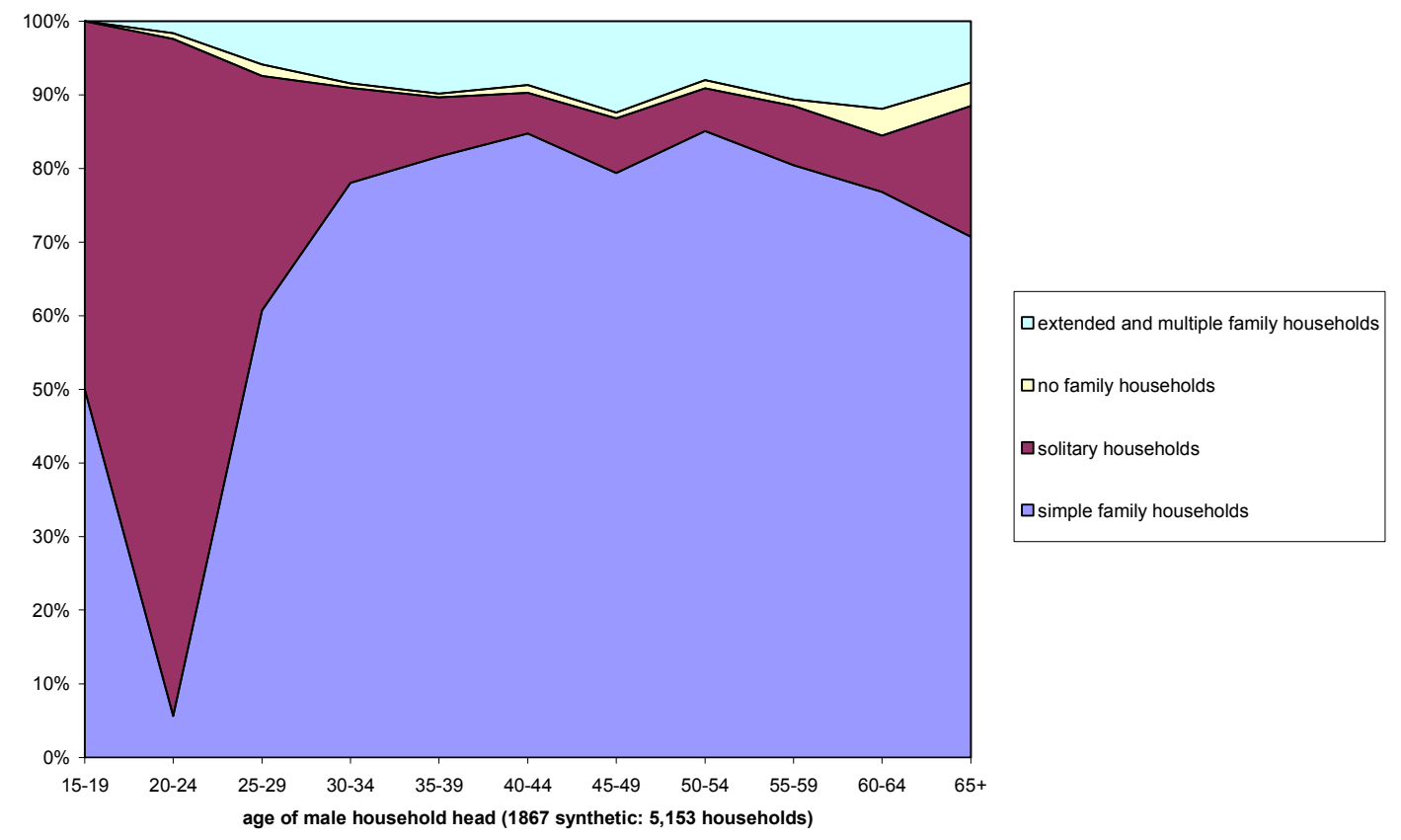

Note: Households of type 6 are excluded.

Figure 6: Household type membership by age, 1819

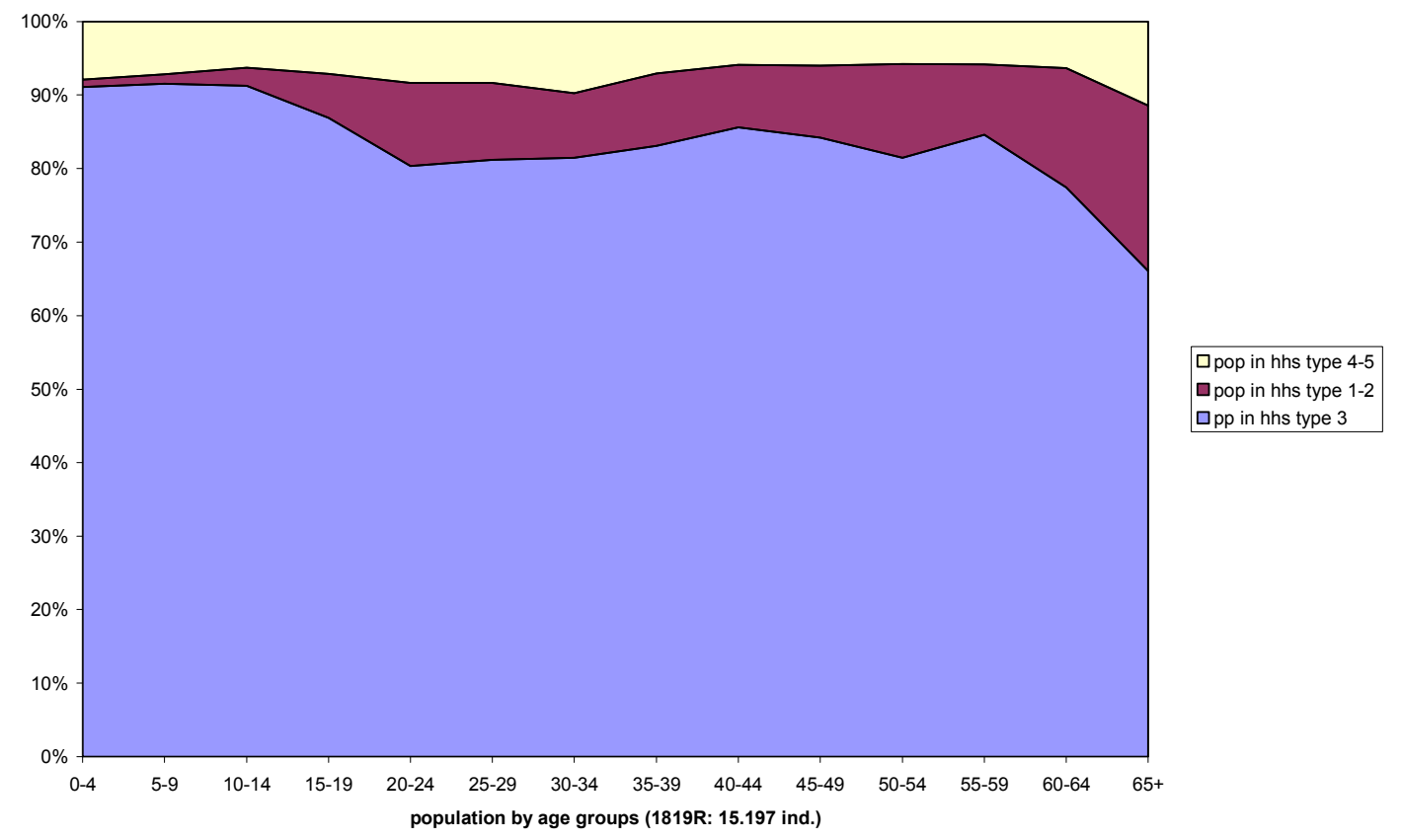

Note: Households of type 6 are excluded. 
Figure 7: Household type membership by age, 1867

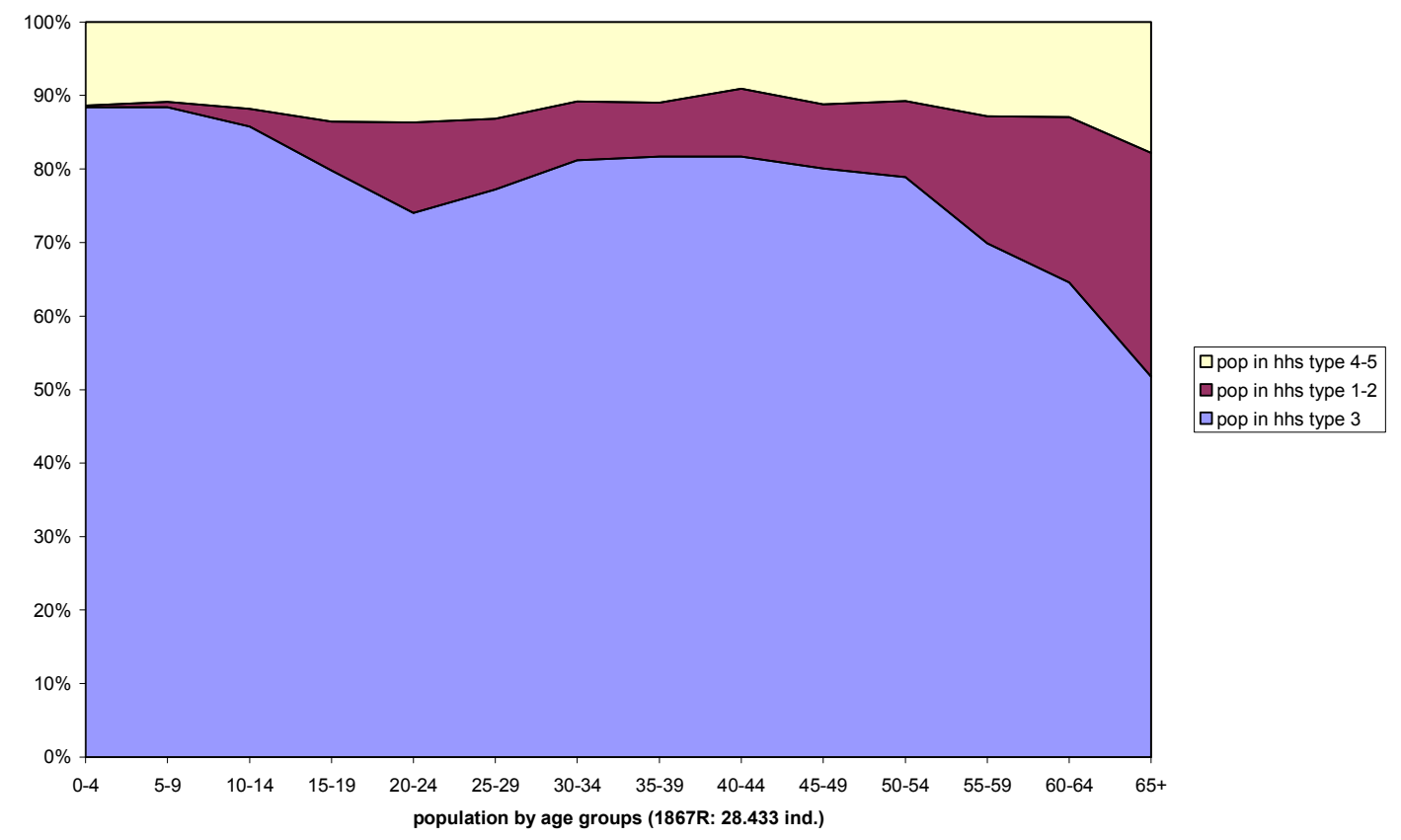

Note: Households of type 6 are excluded.

Figure 8: Household type membership by age, 1819 synthetic

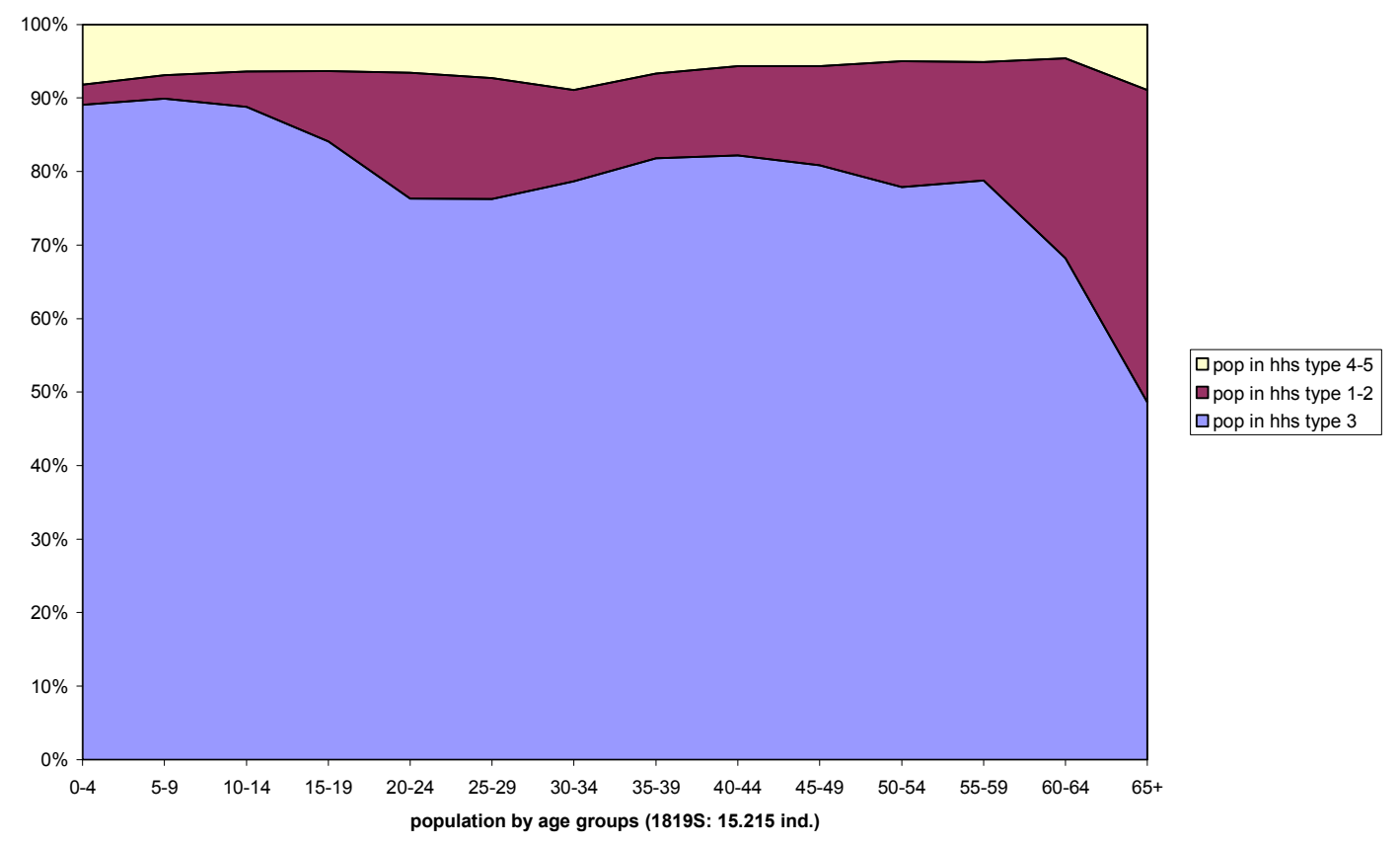

Note: Households of type 6 are excluded. 
Figure 9: Household type membership by age, 1867 synthetic

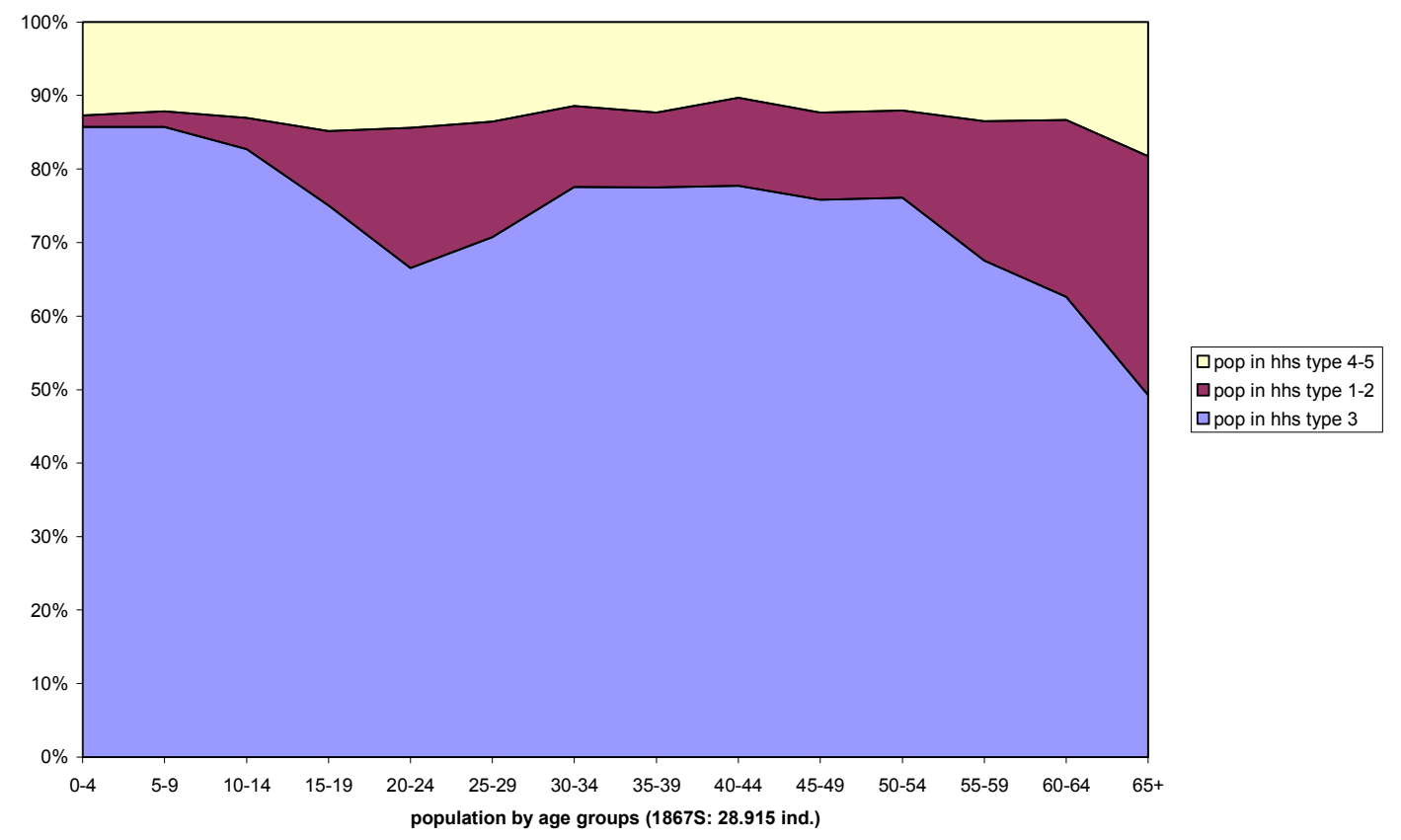

Note: Households of type 6 are excluded.

Figure 10: Population by household size groups

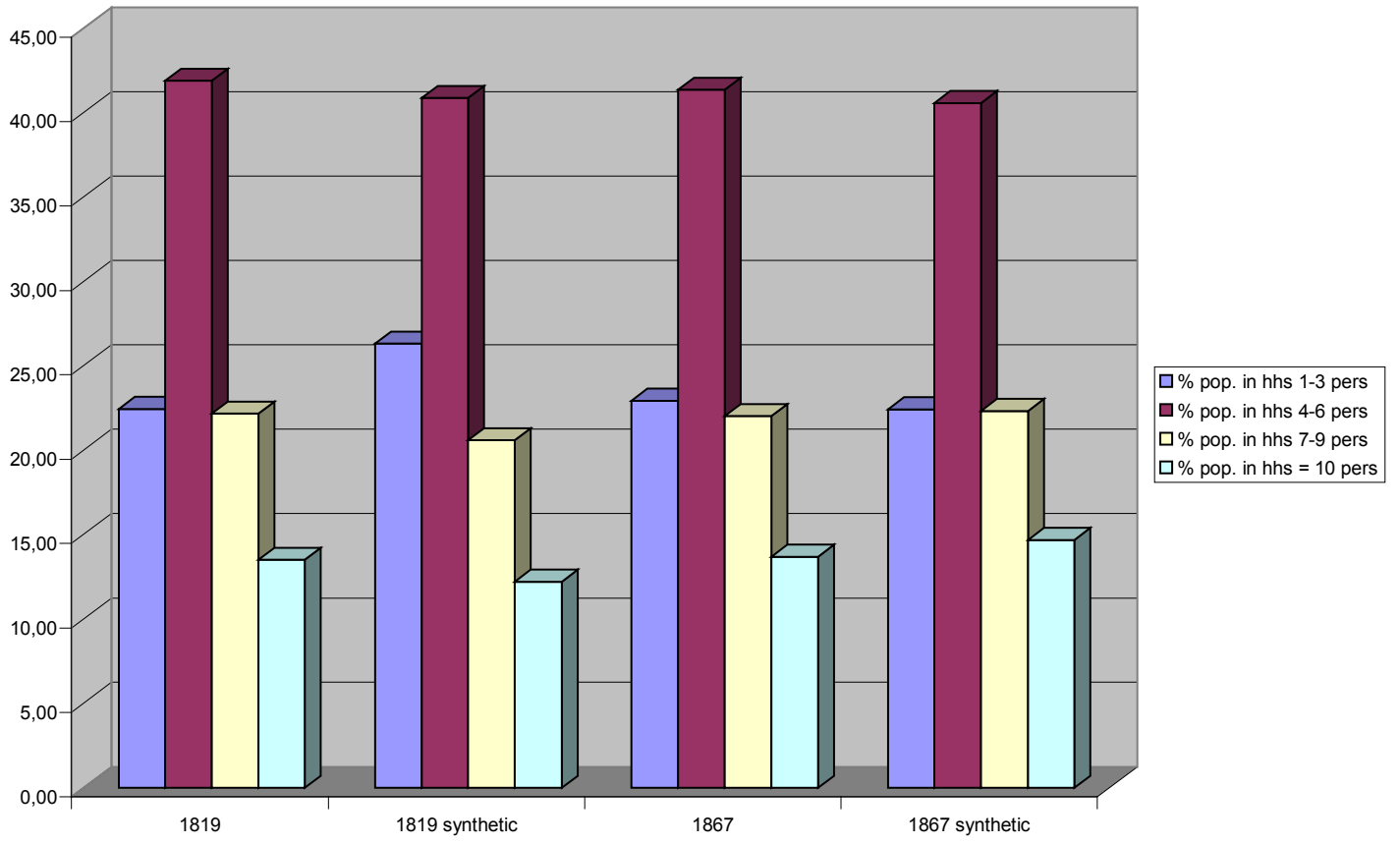


Figure 11: Households by household size groups

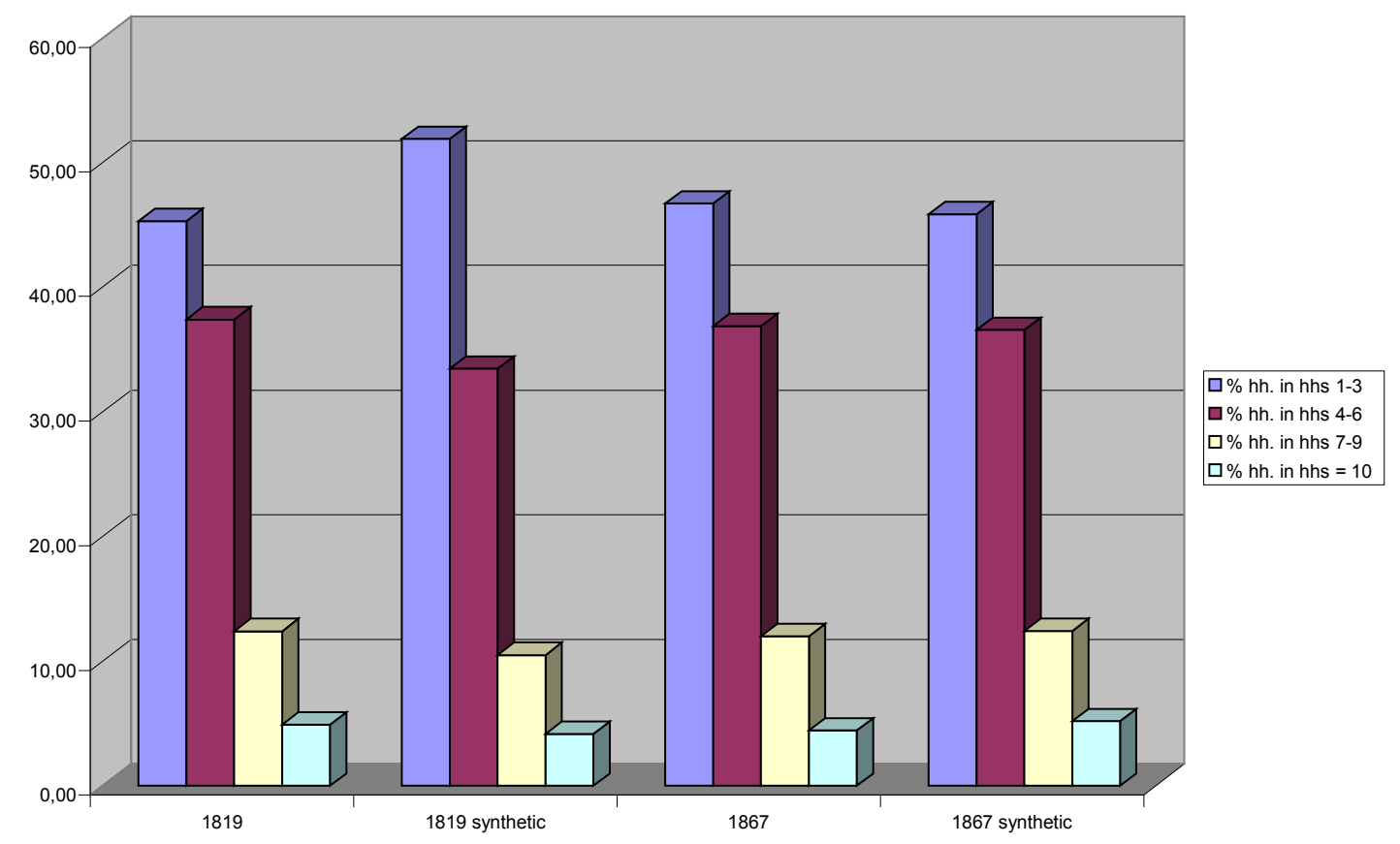

Figure 12: Headship rates of men

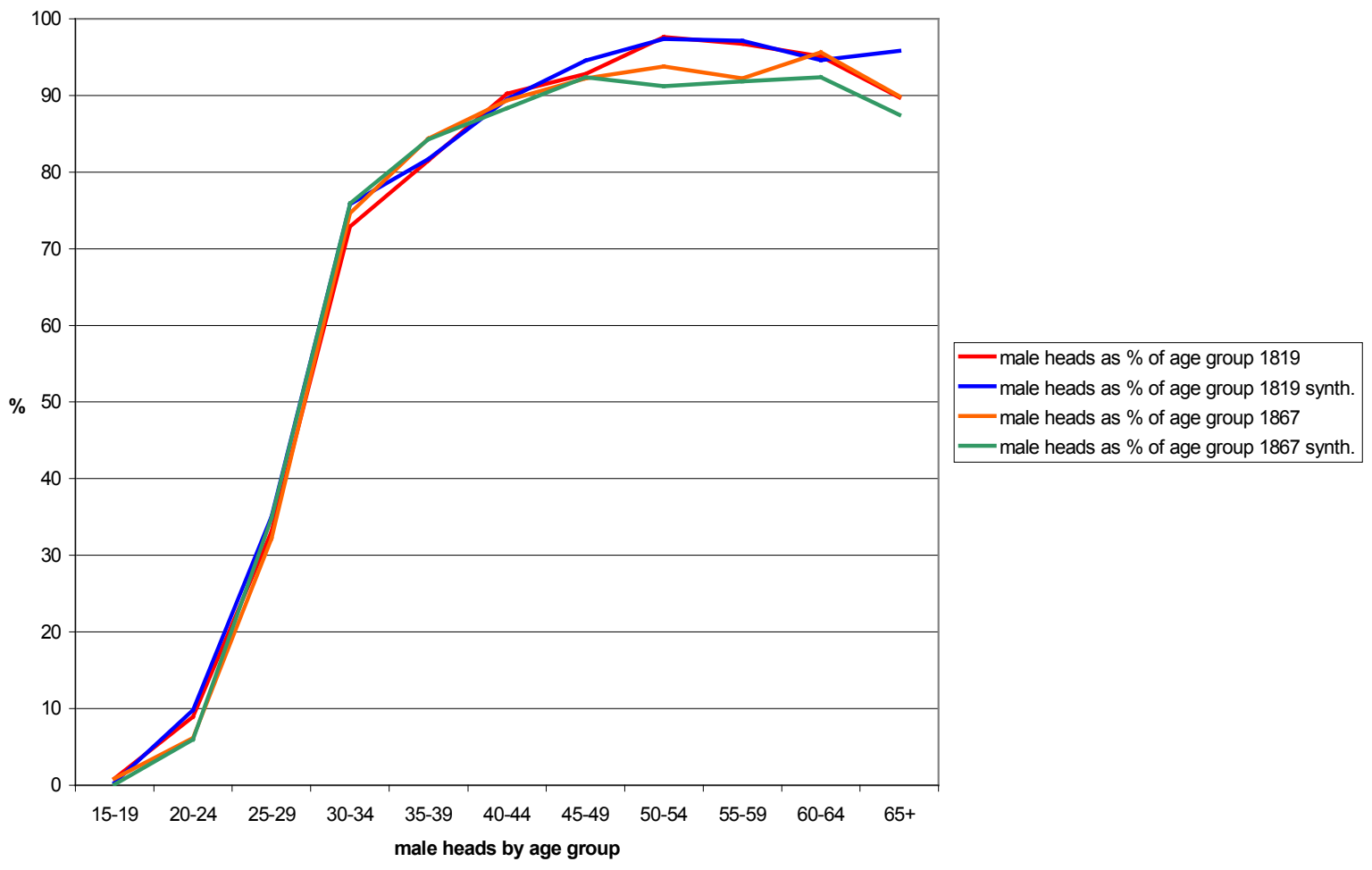

Note: Households of type 6 are excluded. 
Figure 13: Entry into marriage and into headship: males in Rostock 1819 and 1867 (real)

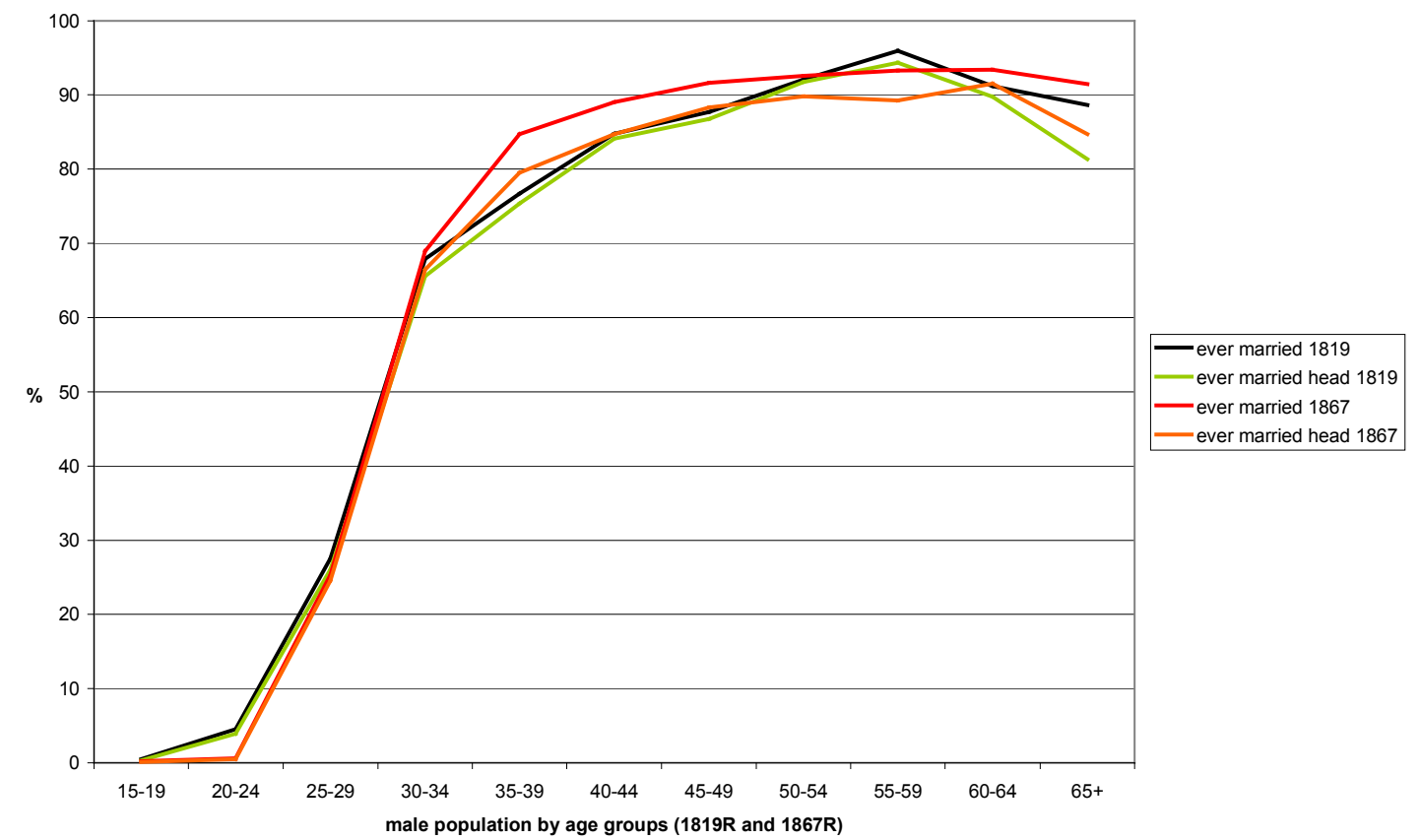

Note: Households of type 6 are excluded.

Figure 14: Entry into marriage and into headship: males in Rostock 1819 and 1867, synthetic files

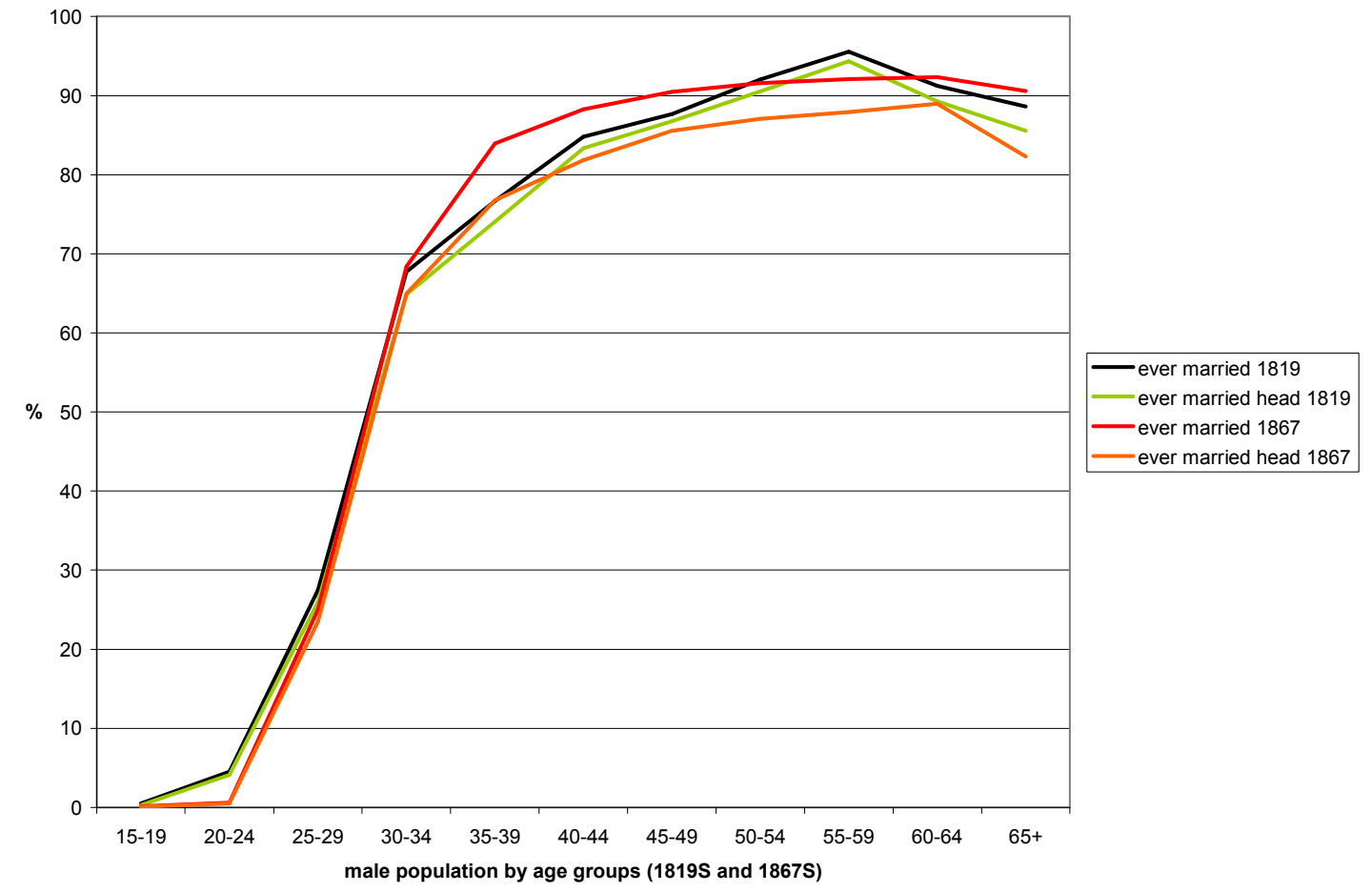

Note: Households of type 6 are excluded. 
Figure 15: Headship rates, ever- and never-married household heads, men by age groups (real)

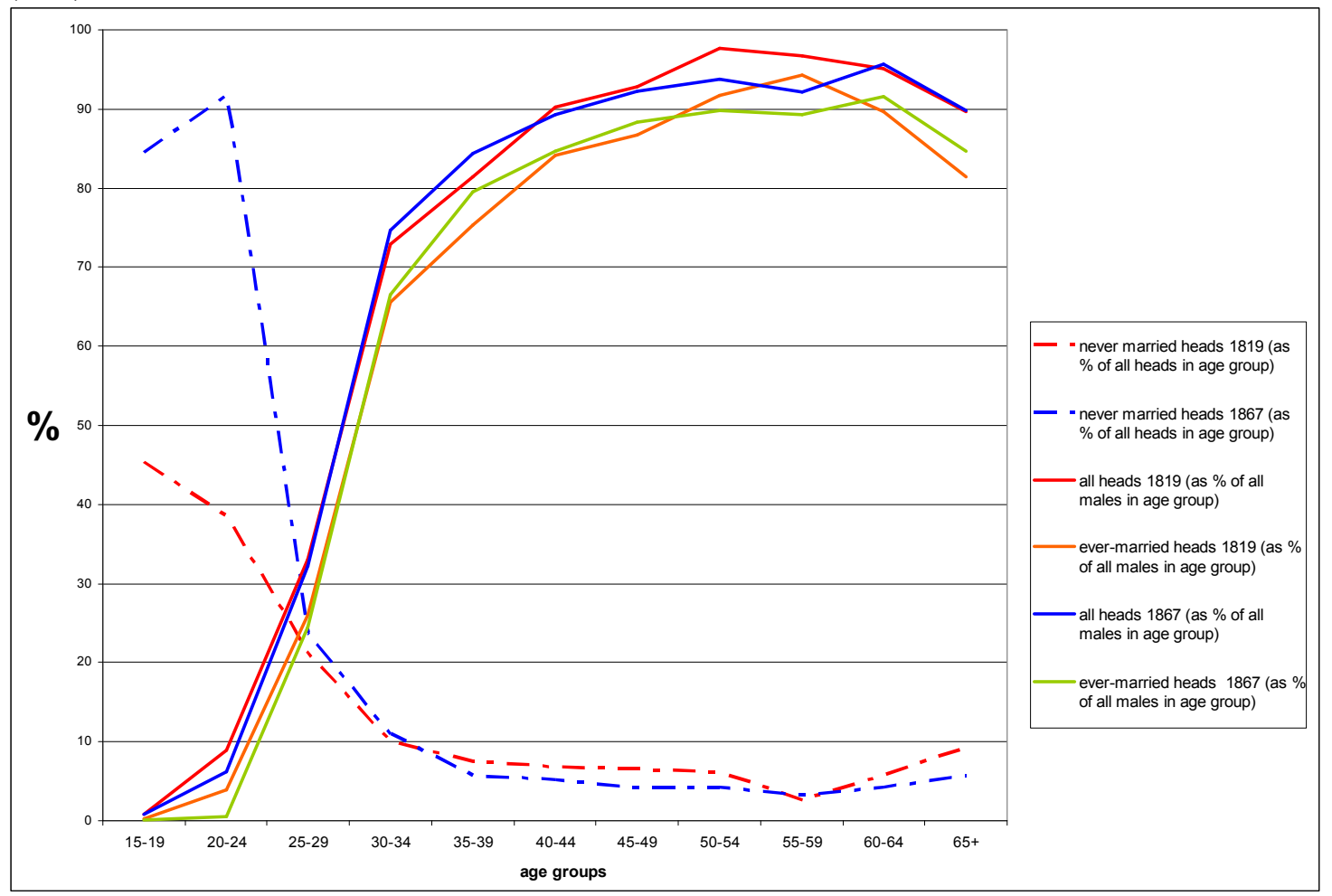

Note: Households of type 6 are excluded

Figure 16: Headship rates and ever married household heads, men by age groups, synthetic files
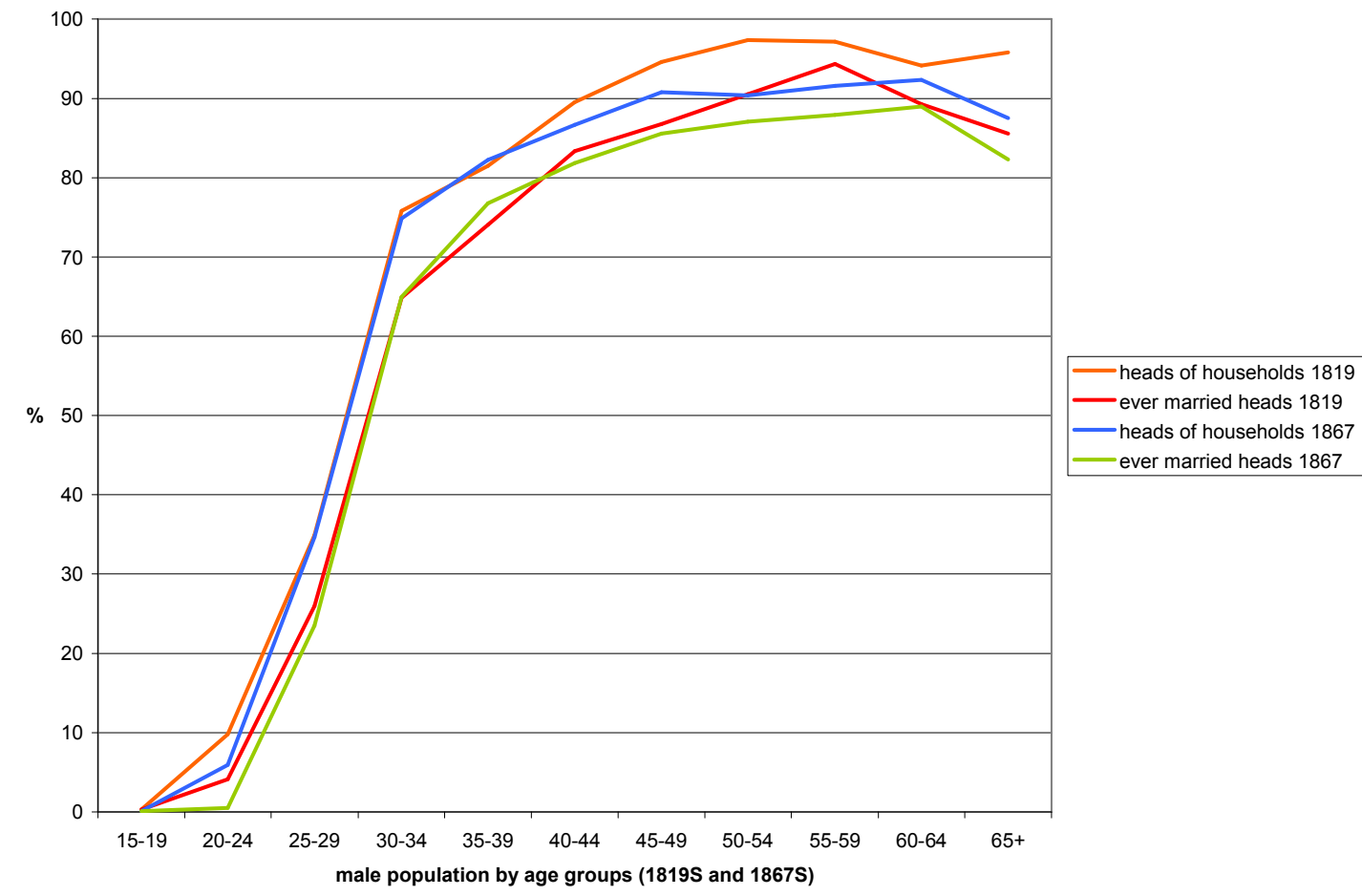

Note: Households of type 6 are excluded. 
Figure 17: Relationship to the household head by age groups, men 1819

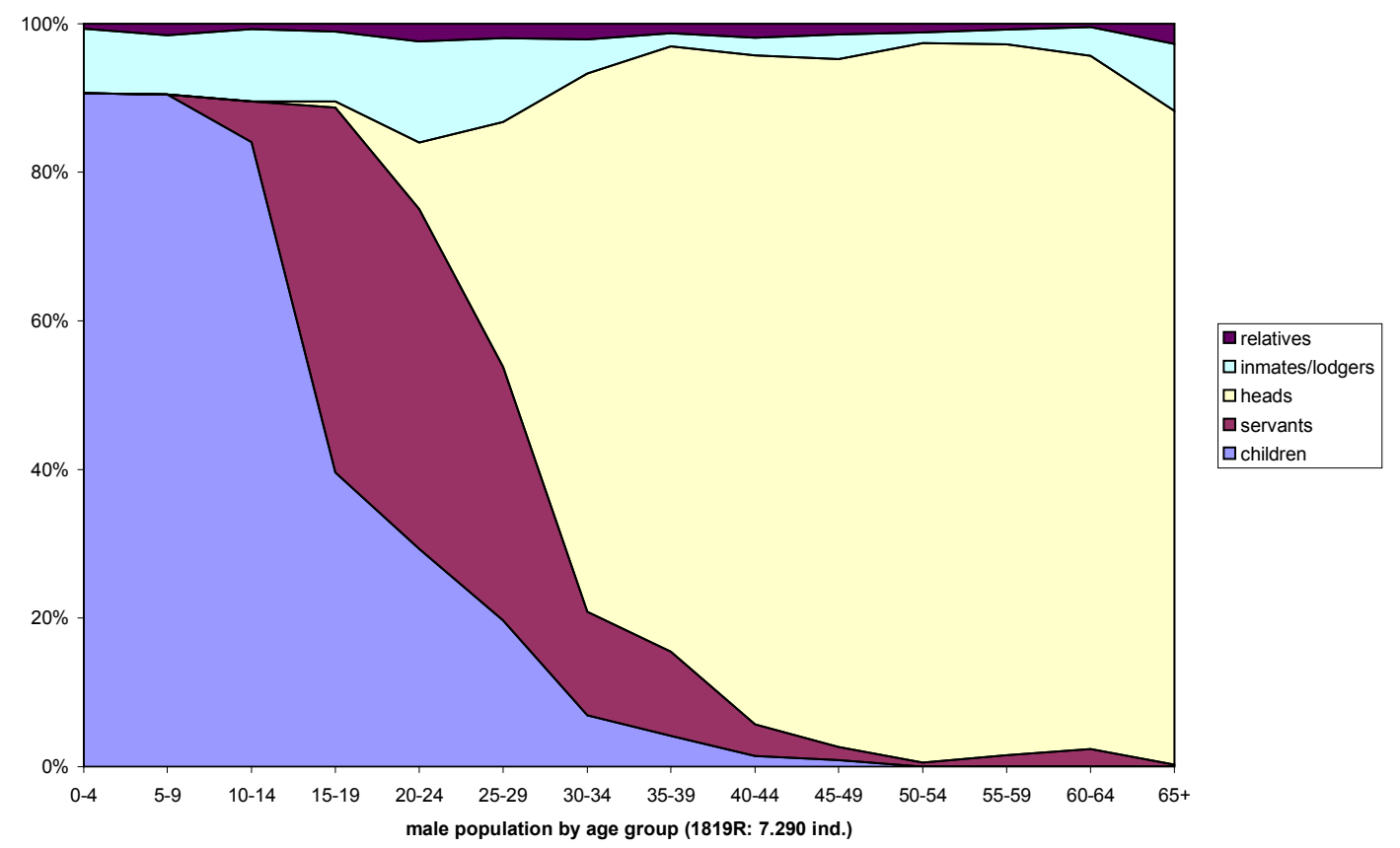

Note: Households of type 6 are excluded.

Figure 18: Relationship to the household head by age groups, men 1867

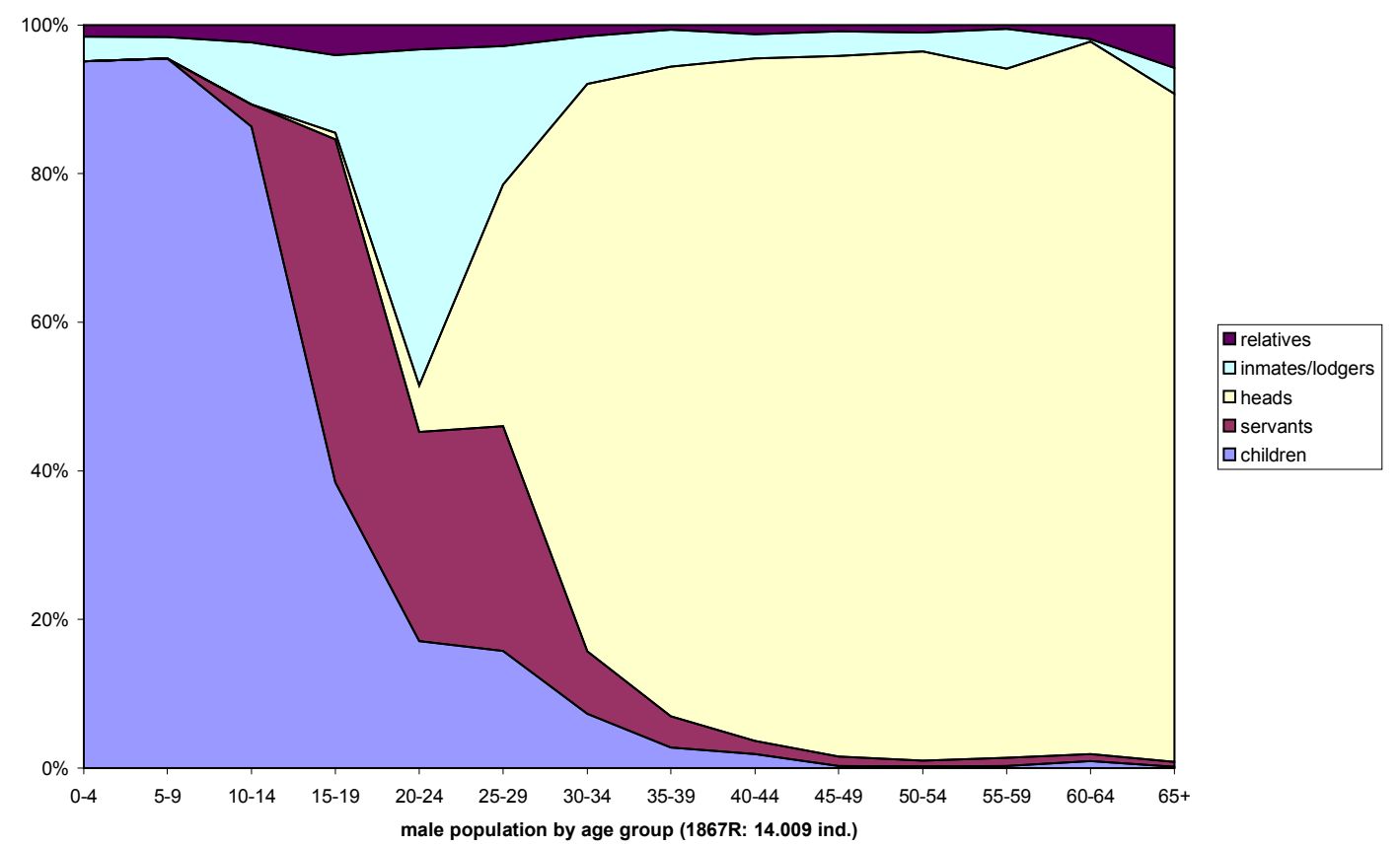

Note: Households of type 6 are excluded. 
Figure 19: Relationship to the household head by age groups, women 1819

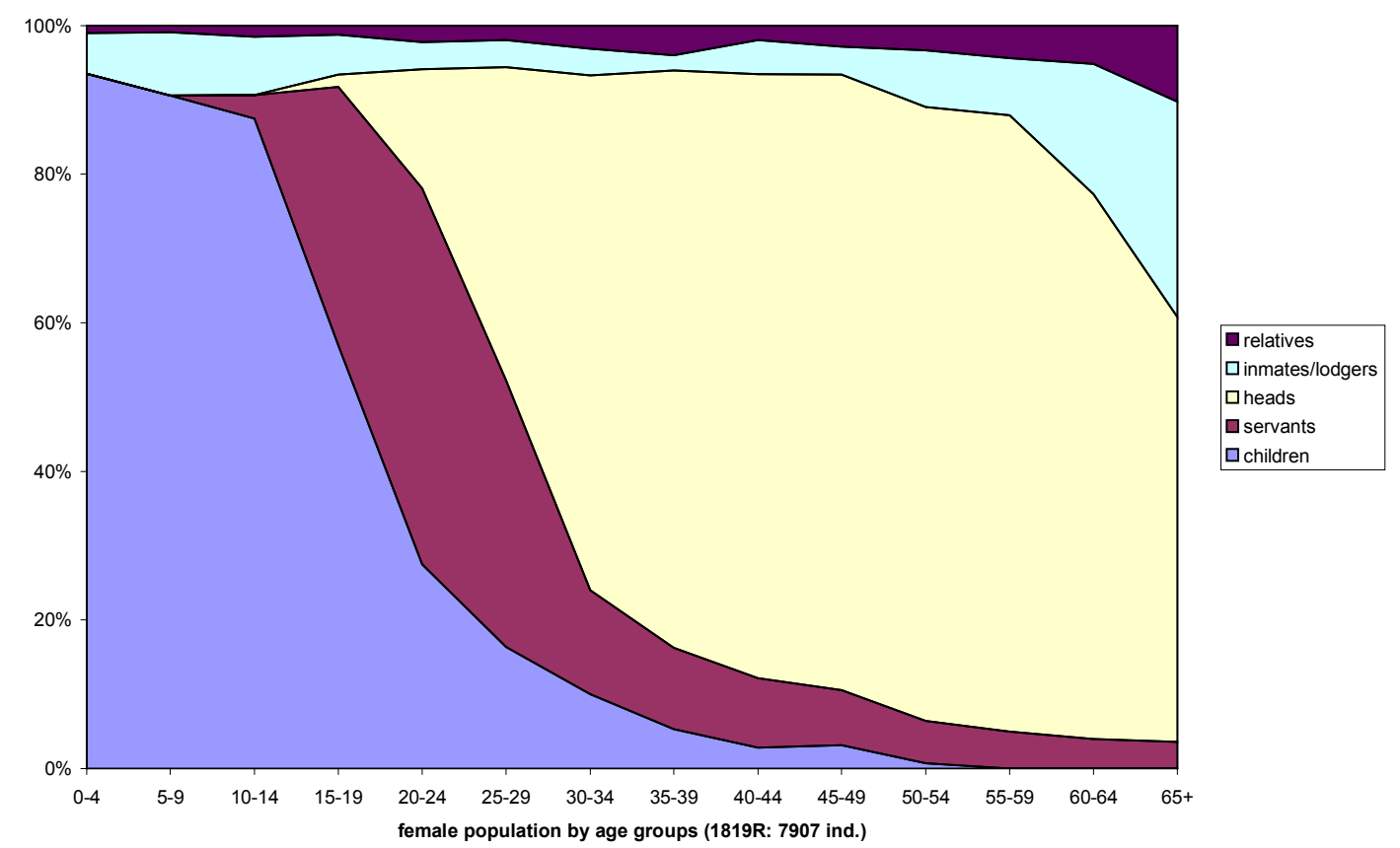

Note: Households of type 6 are excluded.

Figure 20: Relationship to the household head by age groups, women 1867

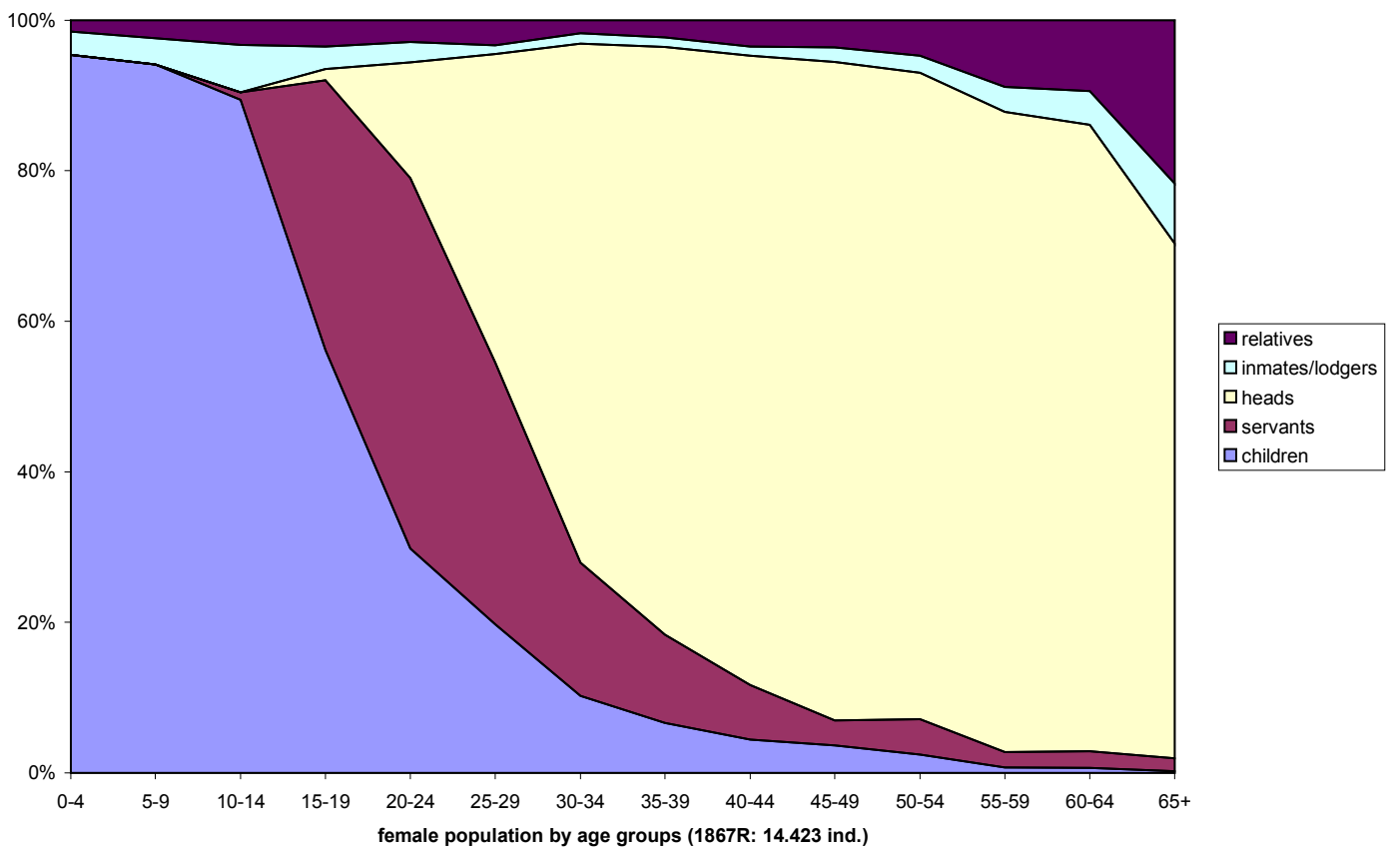

Note: Households of type 6 are excluded. 
Figure 21: Relationship to other members of the household by age groups, males 1819 Males 1819

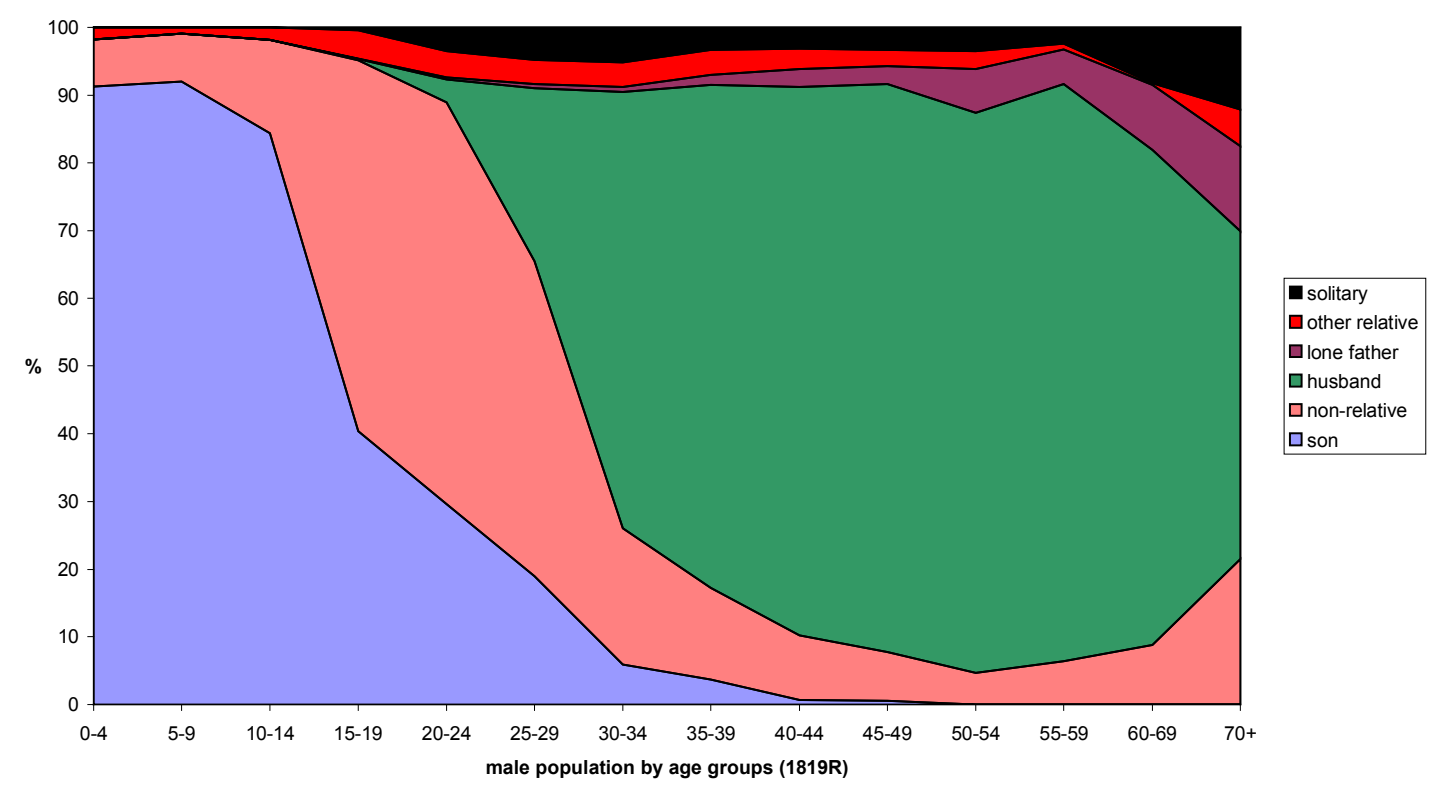

Note: Households of type 6 are excluded.

Figure 22: Relationship to other members of the household by age groups, males 1867

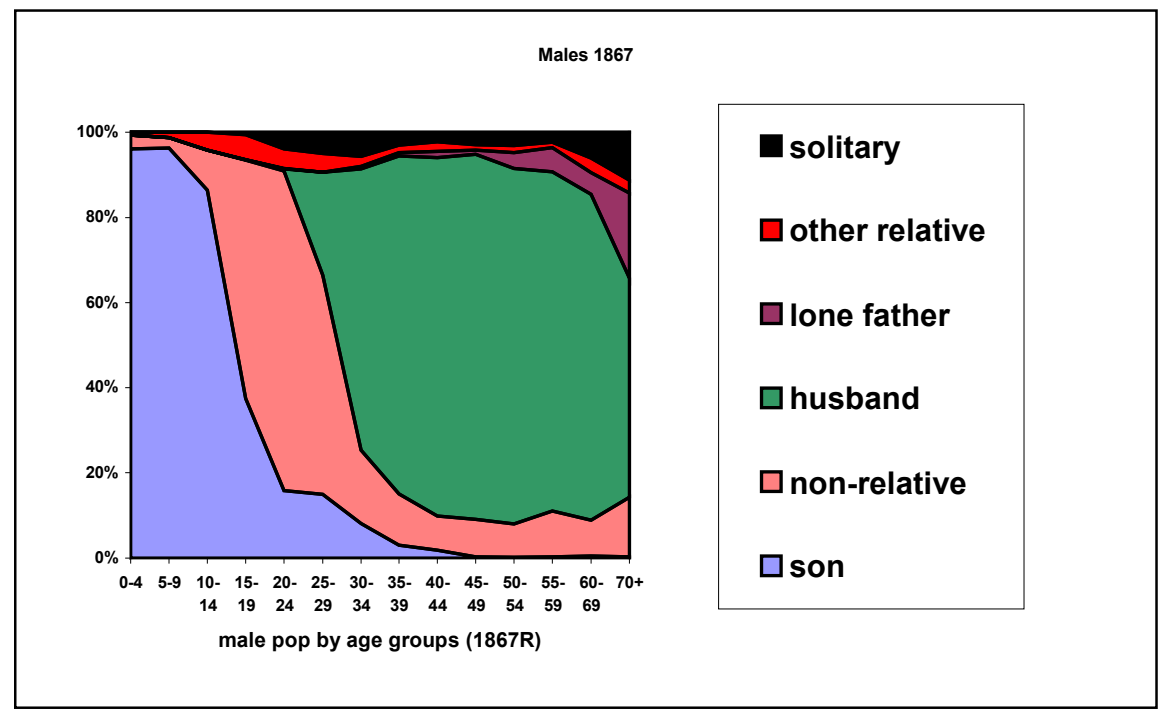

Note: Households of type 6 are excluded. 
Figure 23: Relationship to other members of the household by age groups, females 1819 Females 1819

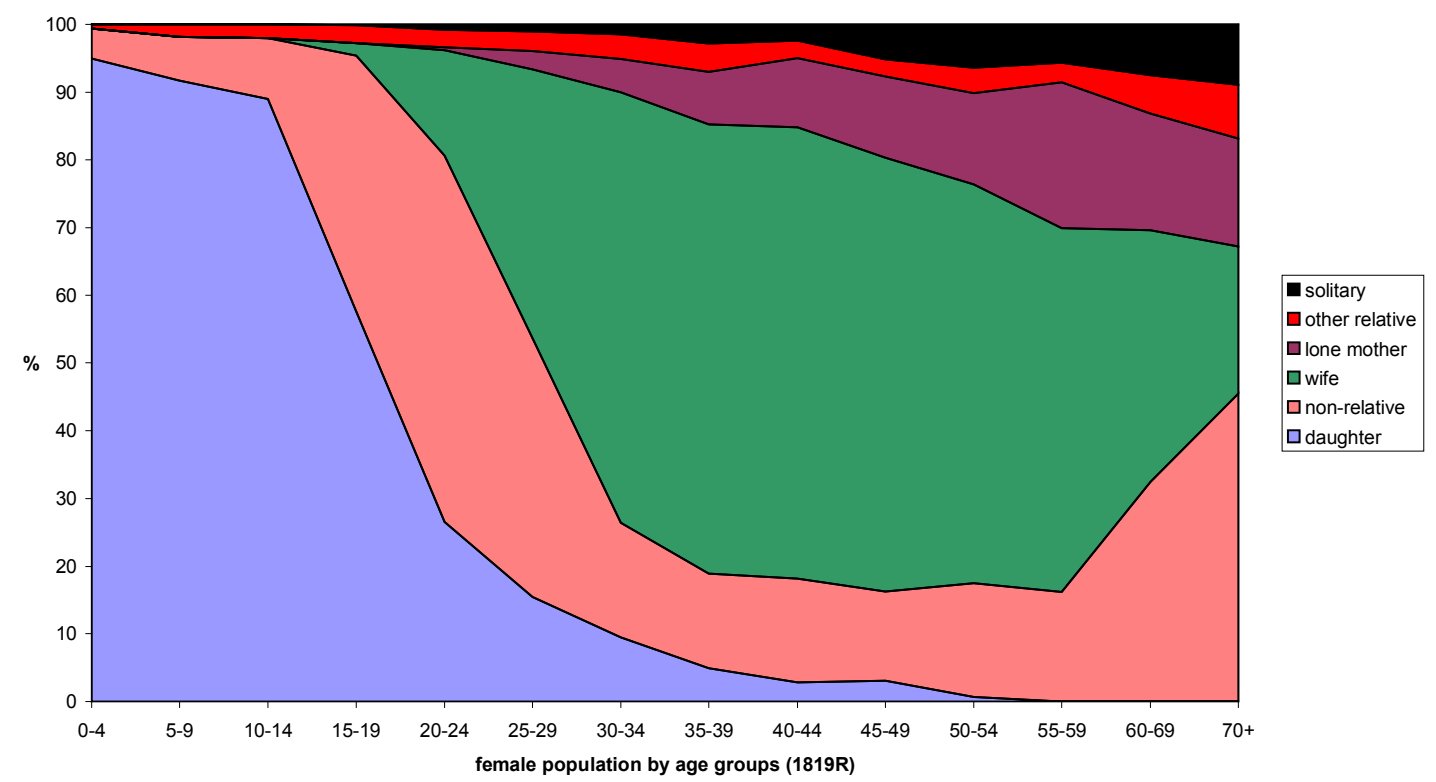

Note: Households of type 6 are excluded.

Figure 24: Relationship to other members of the household by age groups, females 1867

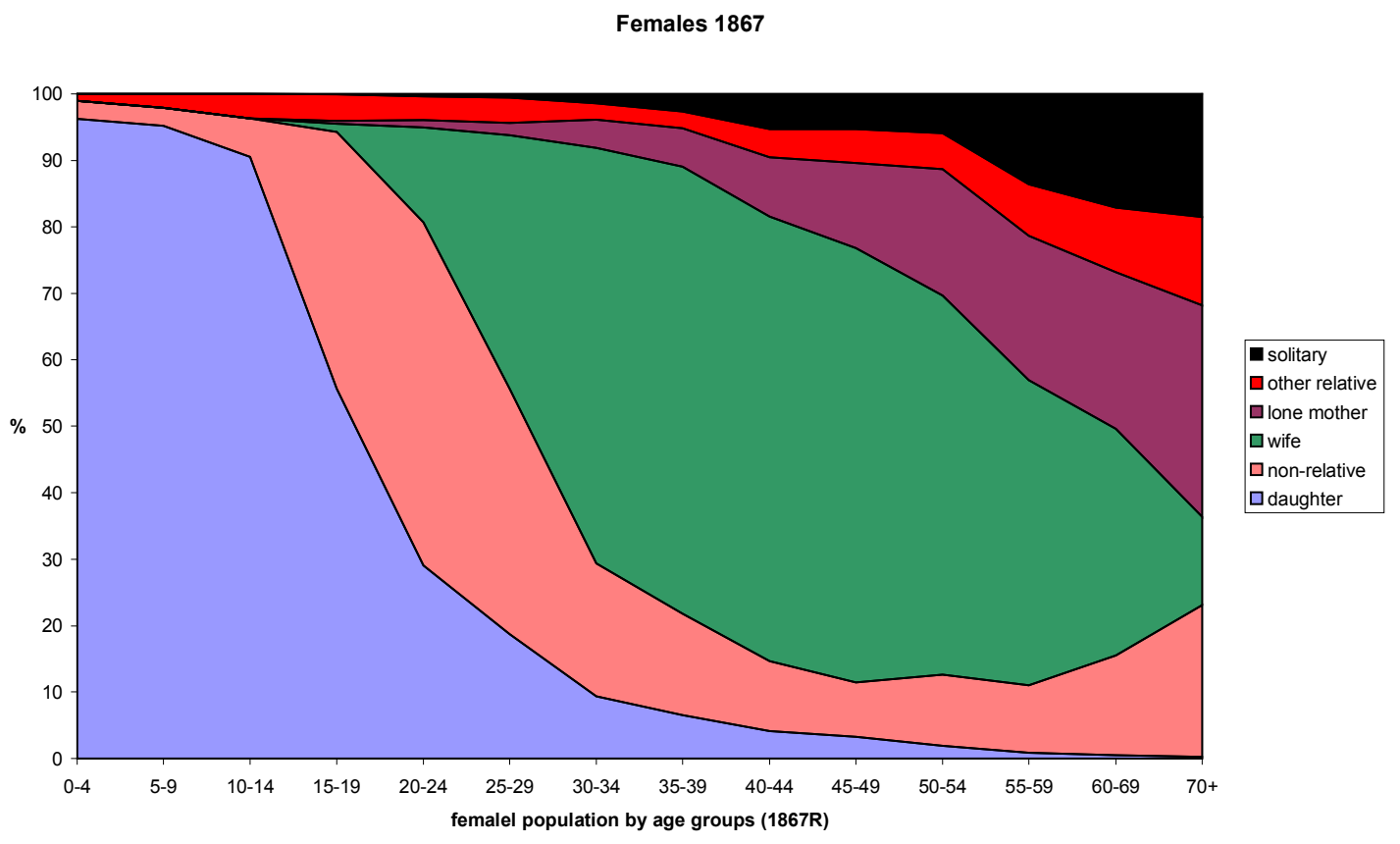

Note: Households of type 6 are excluded. 
Figure 25: Living with the own father by age group

Living with father

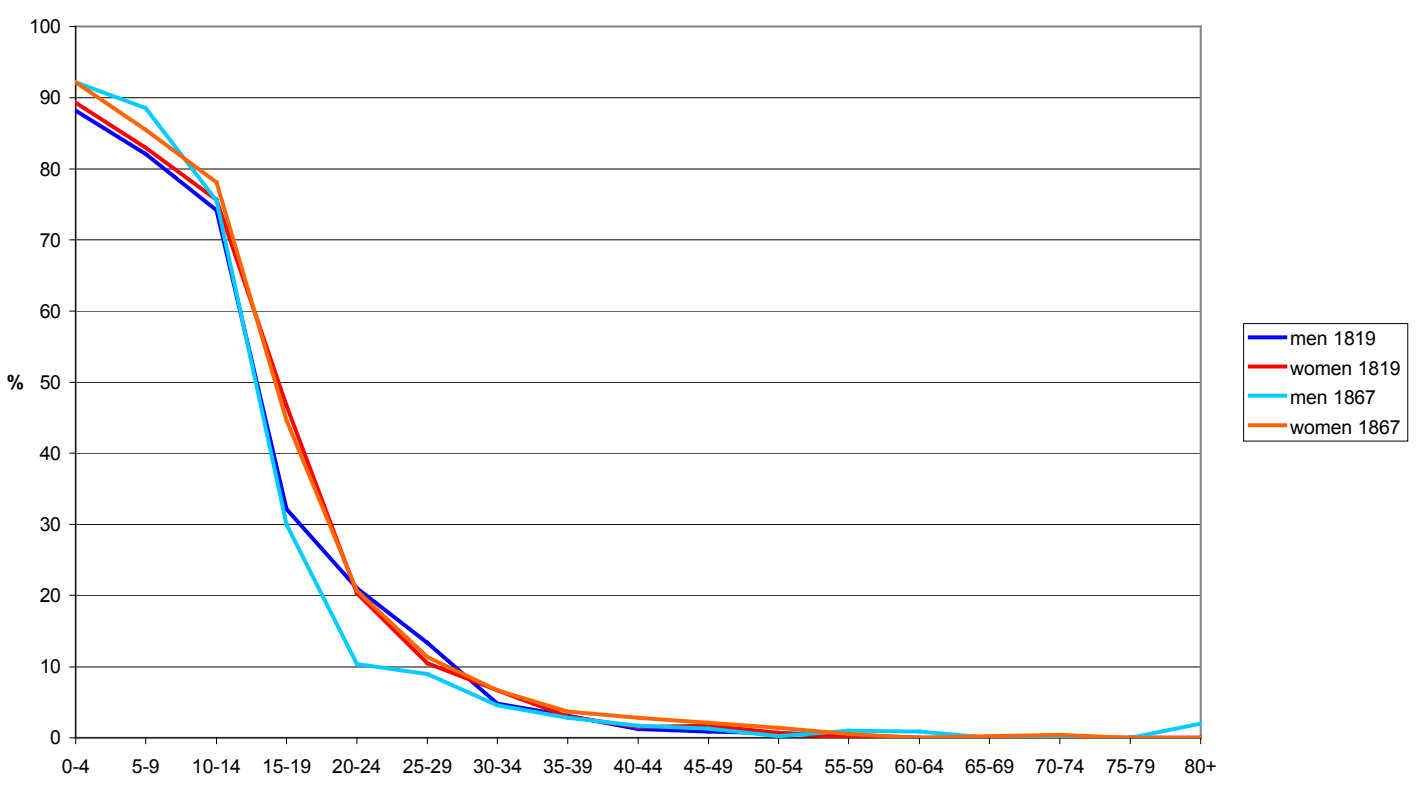

Figure 26: Living with the own mother by age group

Living with mother

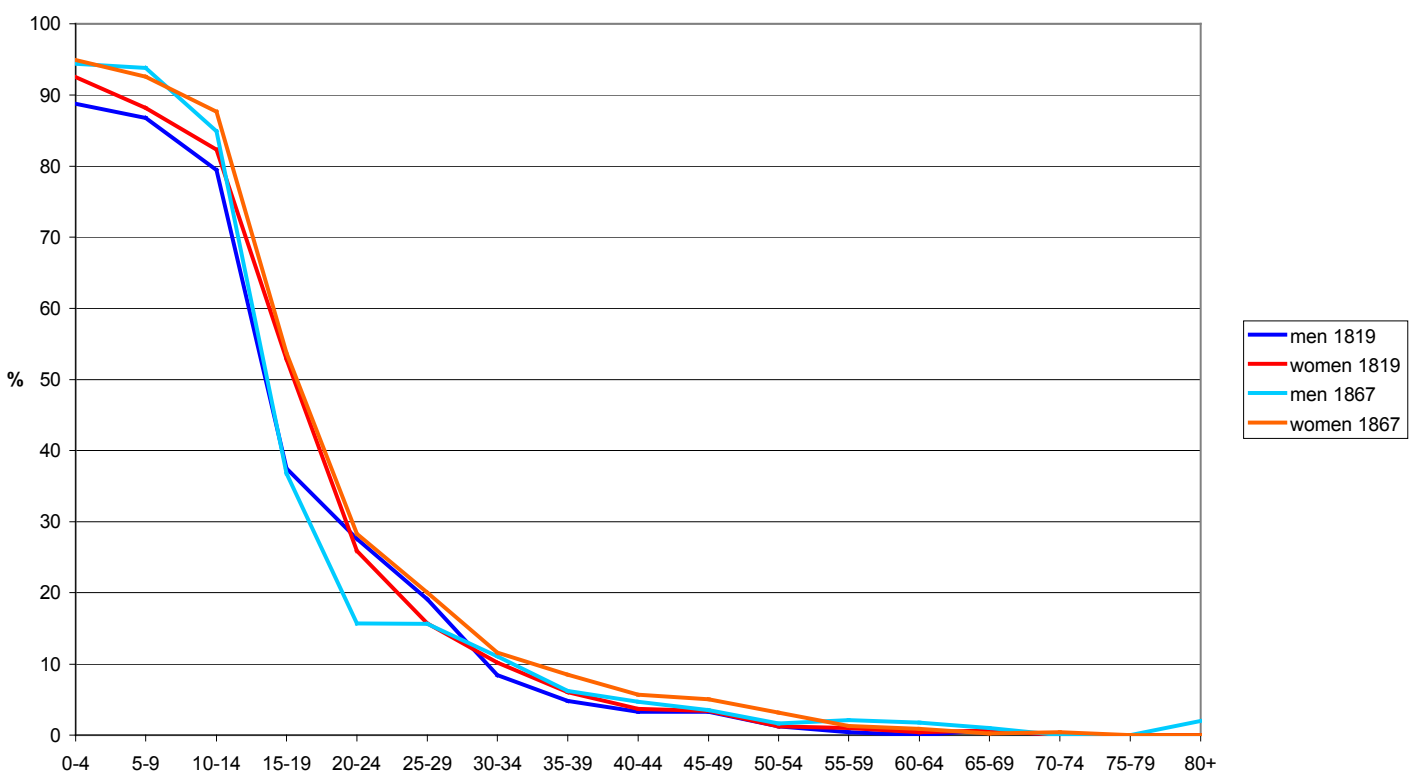


Figure 27: Living with an own child by age group

Living with child

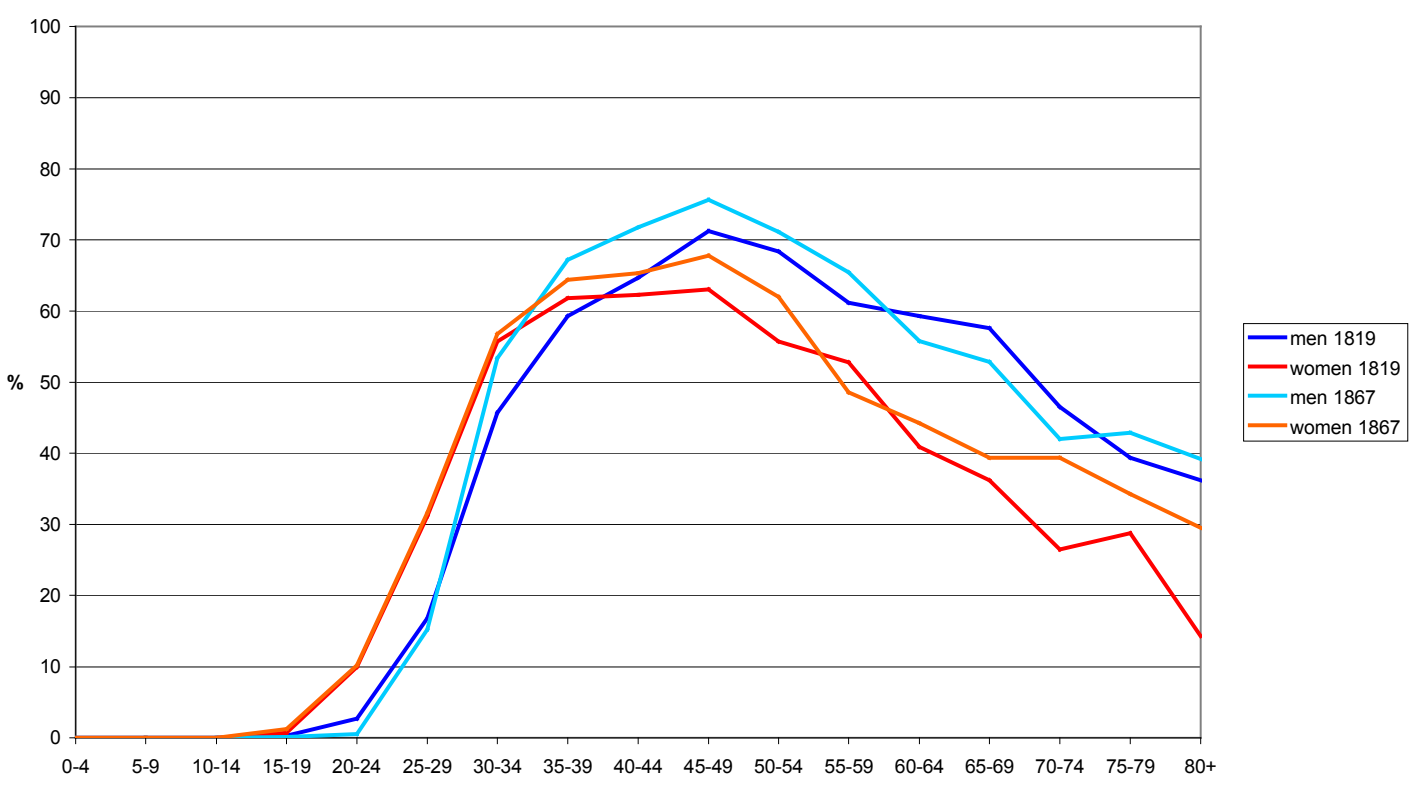

Figure 28: Proportions of men still living at home by age groups

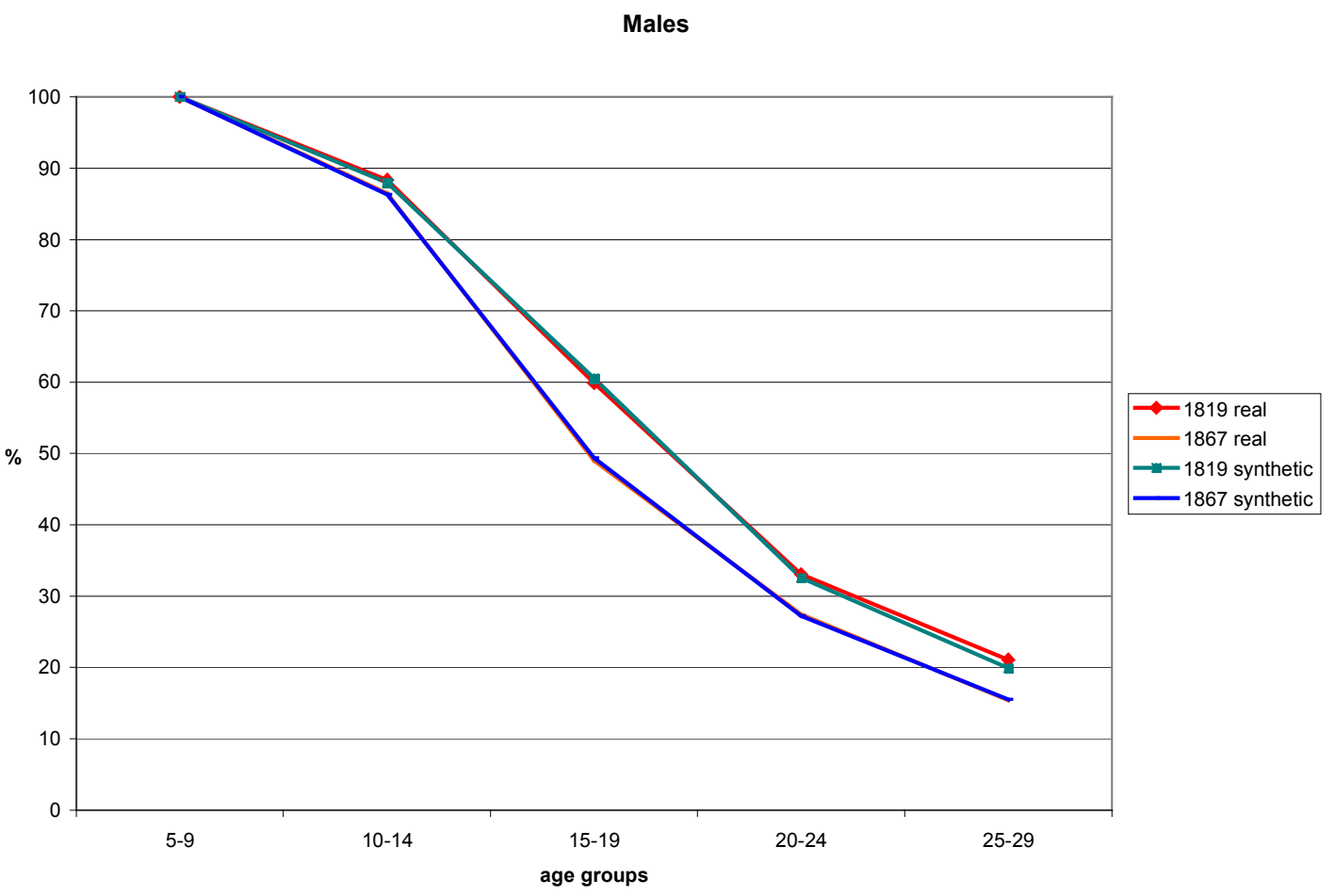

Note: Households of type 6 are excluded. 
Figure 29: Proportions of women still living at home by age groups

Females

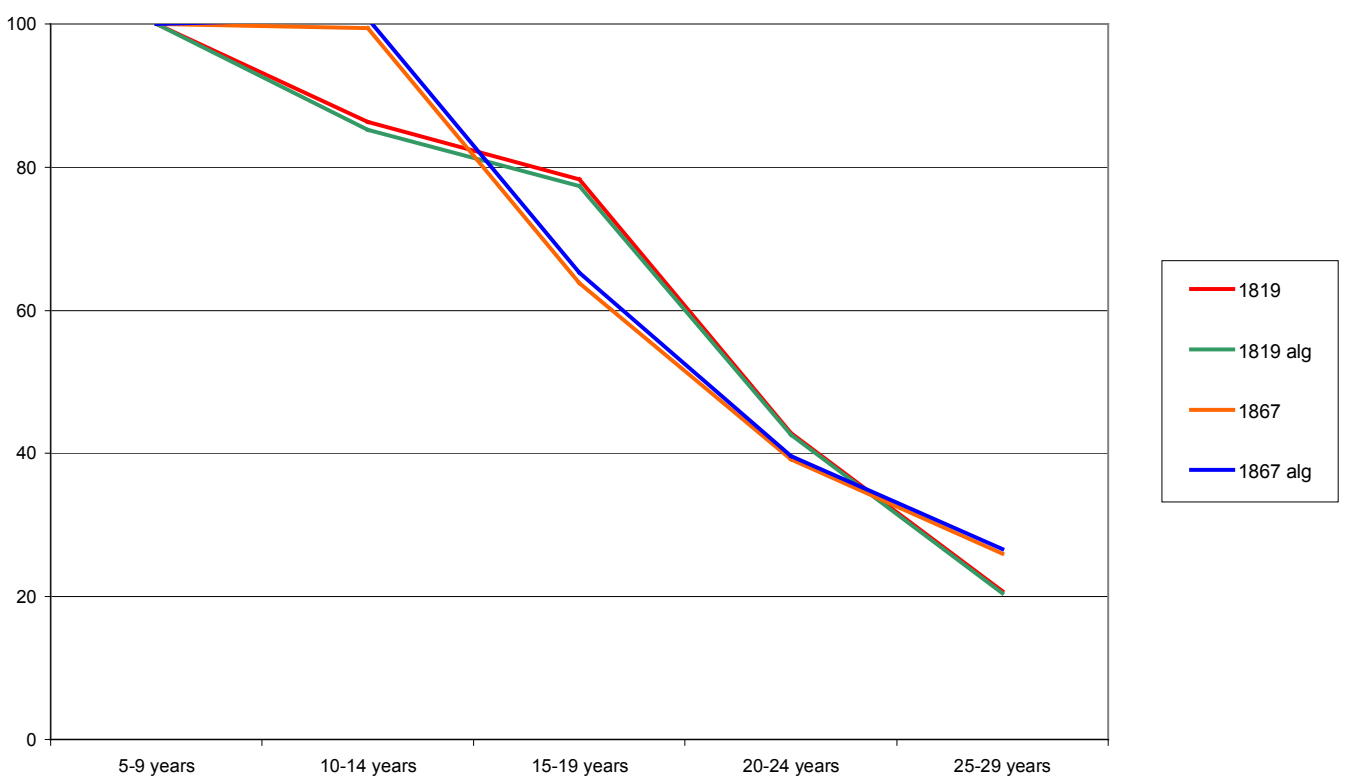

Note: Households of type 6 are excluded.

Figure 30: Residential patterns of men aged 65+

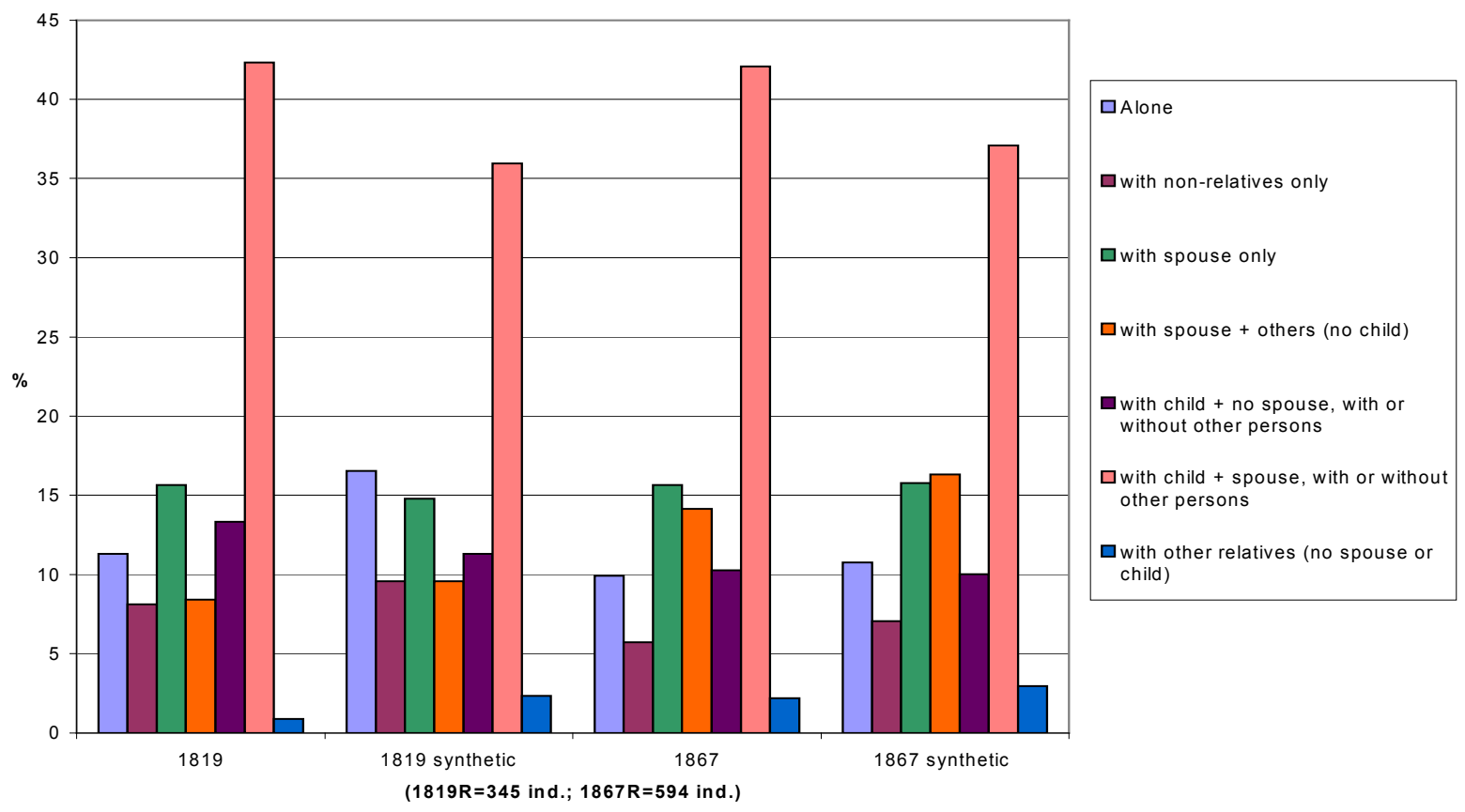

Note: Household heads or their spouses only. 
Figure 31: Residential patterns of women aged $65+$

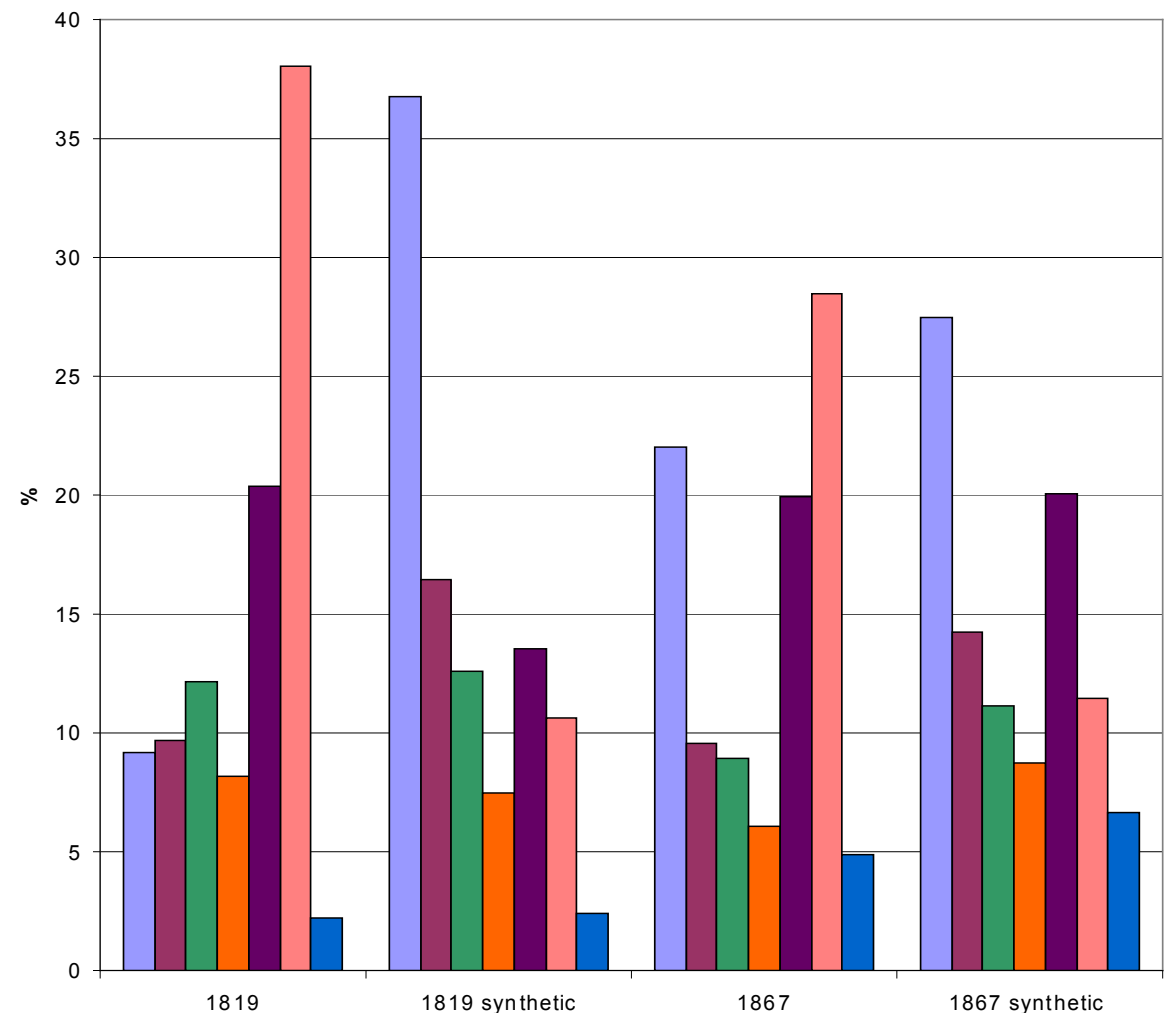

\begin{tabular}{|l}
$\square$ Alone \\
$\square$ with non-relatives only \\
$\square$ with spouse only \\
$\square$ with spouse + others (no child) \\
$\square$ with child + no spouse, with or \\
without other persons \\
$\square$ with child + spouse, with or without \\
other persons \\
$\square$ with other relatives (no spouse or \\
child)
\end{tabular}

Note: Household heads or their spouses only.

Figure 32: Servants as percentage of population by age groups

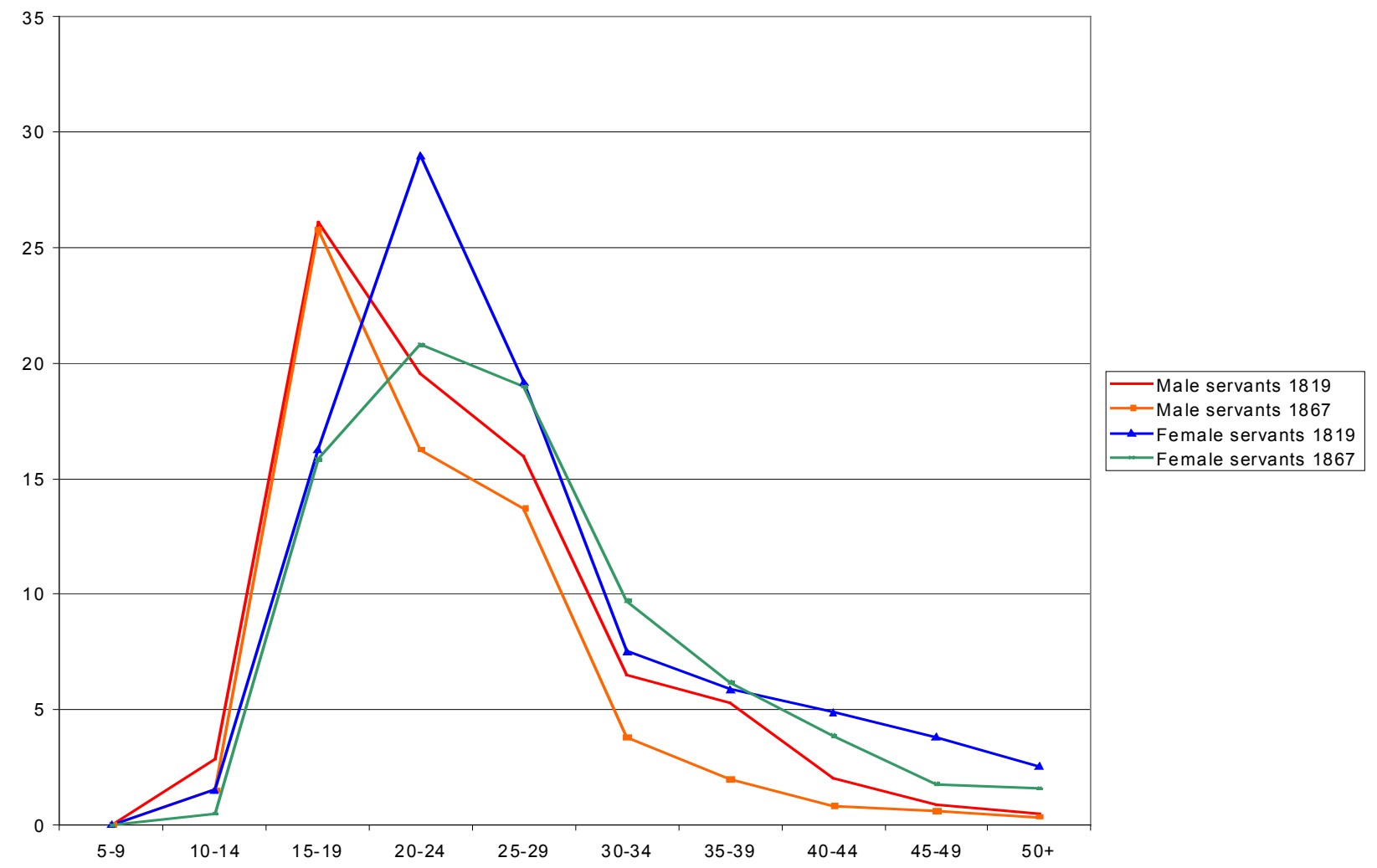


Figure 33: Distribution of servants by age groups
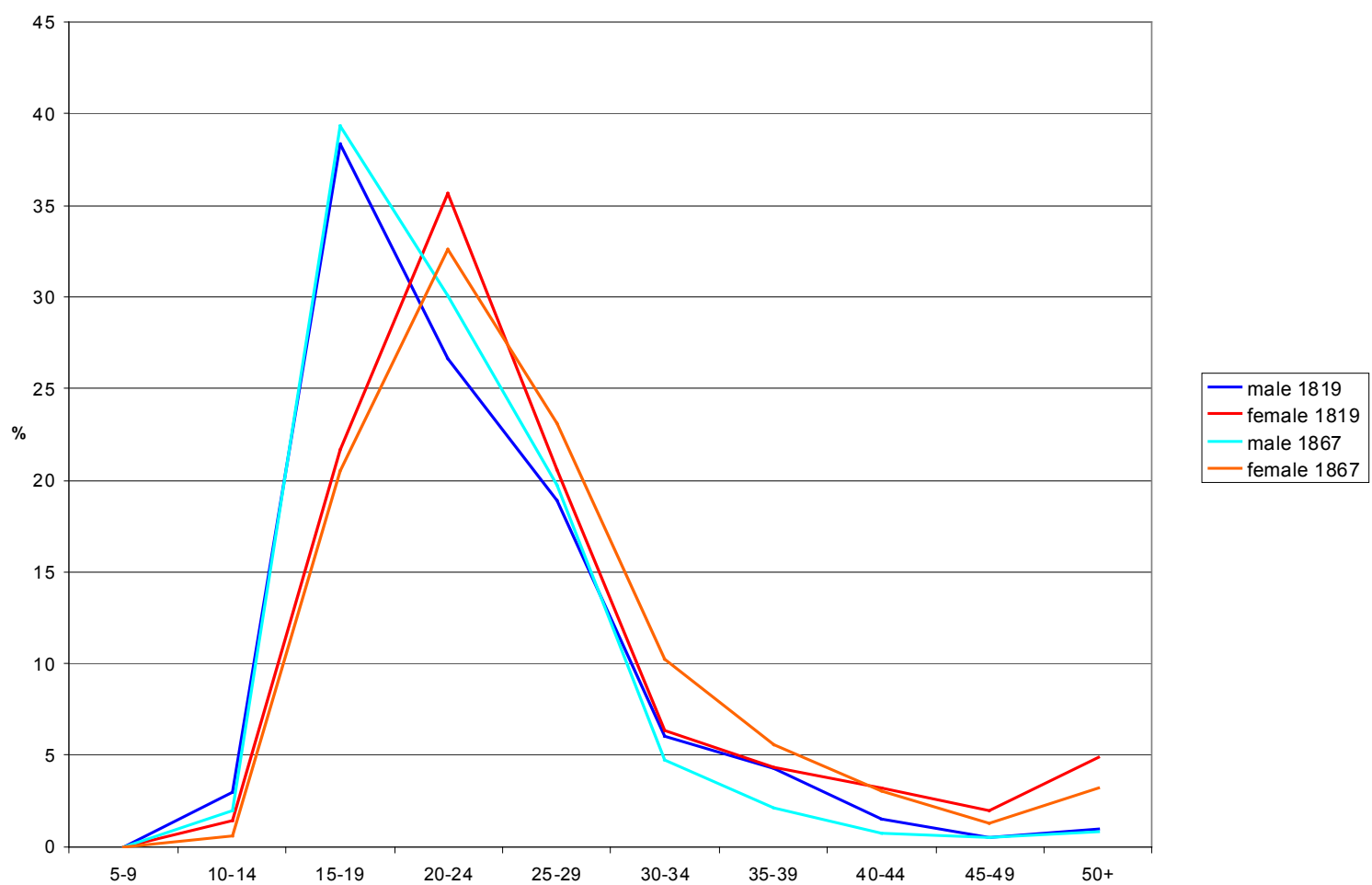

Figure 34: Proportion of households with servants by age of household heads

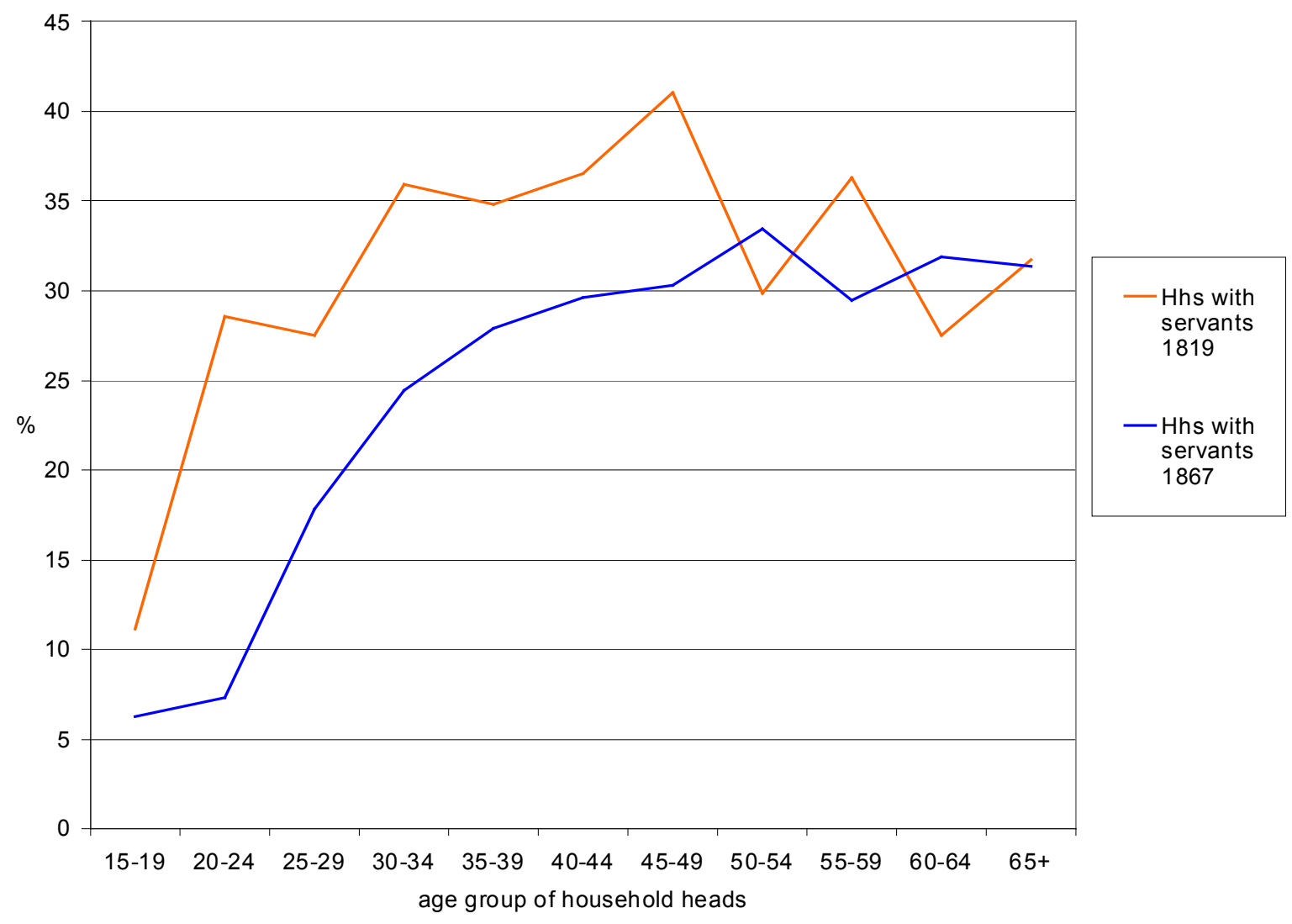

Note: Households of type 6 are excluded. 
Figure 35: Number of offspring and servants by age of household head

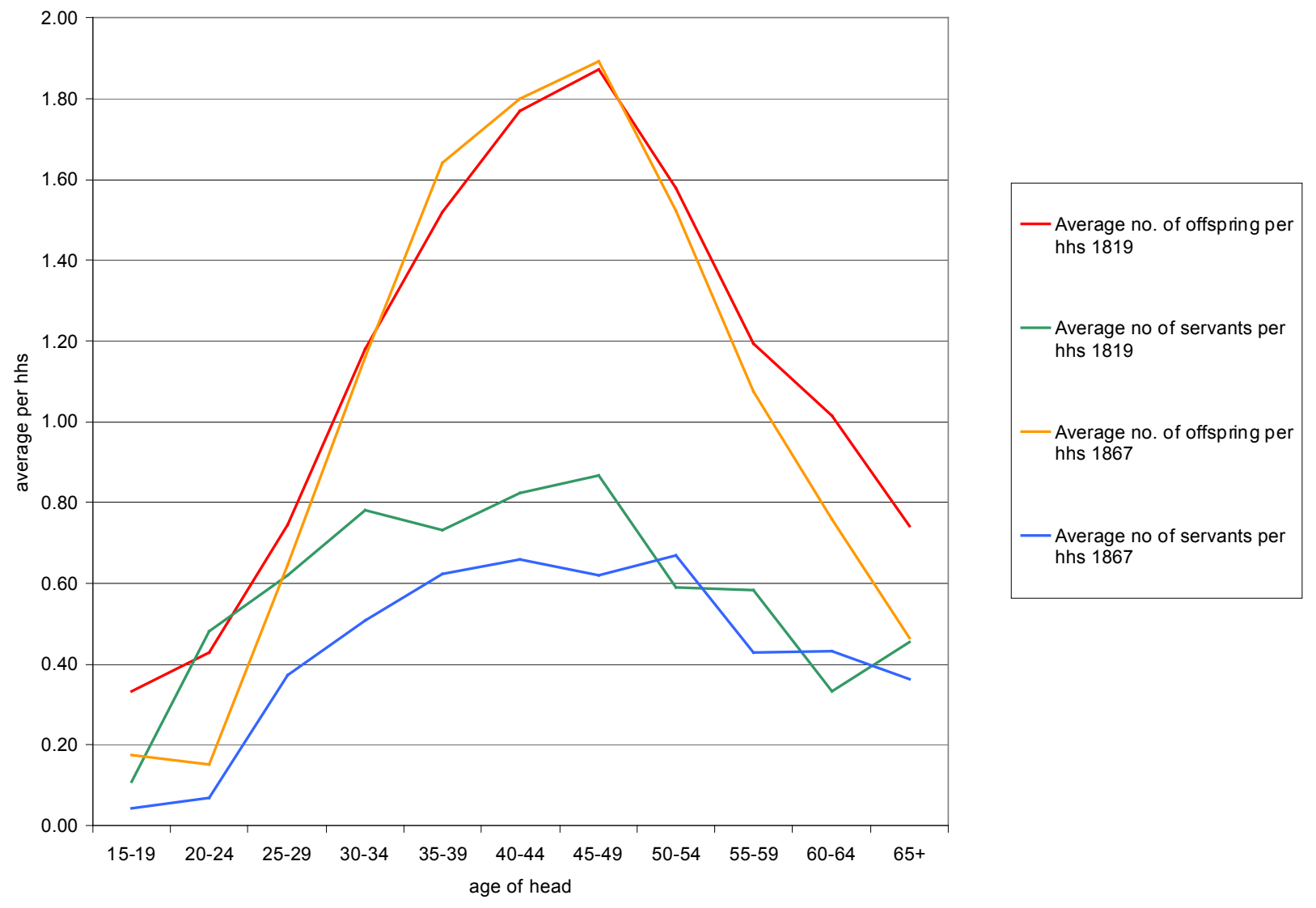

Note: Households of type 6 are excluded. 